UNIVERSIDADE DE SÃO PAULO - USP

ESCOLA DE COMUNICAÇÕES - ECA

\title{
A QUESTÃO DA SAÚDE PÚBLICA: UM ENFOQUE COMUNICACIONAL
}

\author{
DISSERTAÇÃO DE MESTRADO \\ DEVANI SALOMÃO DE MOURA REIS
}

ORIENTADORA

PROF. DR. ${ }^{\text {a HELOIZA MATOS }}$

SÃO PAULO 


\title{
DEVANI SALOMÃO DE MOURA REIS
}

\section{A QUESTÃO DA SAÚDE PÚBLICA: UM ENFOQUE COMUNICACIONAL}

\begin{abstract}
Dissertação apresentada ao Departamento de Relações Públicas, Propaganda e Turismo da Escola de Comunicações e Artes da Universidade de São Paulo (ECA/USP), como requisito parcial para a obtenção do Título de Mestre em Ciências da Comunicação, sob a orientação da Professora Dr. ․ Heloiza Matos.
\end{abstract}

\section{SÃO PAULO}


Dissertação defendida em de de 1999

Banca Examinadora

Presidente

1을 $)$ examinador (a)

$2^{\circ}(\stackrel{a}{)})$ examinador $(\mathrm{a})$

Escola de Comunicações e Artes - USP 


\section{Dedicatória}

Dedico esta dissertação aos meus filhos Leonardo, Eduardo, Fernanda e Victor por tudo que me ensinaram, pelo incentivo recebido em todos os momentos difíceis e por terem demonstrado que os nossos limites são por nós determinados. 
Agradecimentos

A Profa. Dra. Heloisa Matos sou grata não apenas pelo acompanhamento acurado do meu trabalho, orientando-me com precisão e competência indiscutíveis, mas também pelo apoio e estímulo que me dispensou ao longo de todo o mestrado.

A Profa. Dra. Margarida Krohling Kunsch cuja competência e zelo terão sempre o meu reconhecimento pois foi fundamental para esse trabalho. Devo a ela muito do que consegui compreender sobre comunicação.

A Dra. Janete Simiema que no exame de qualificação foi fértil em indicações, às quais essa dissertação, nos seus modestos limites, tentou dar as merecidas consequências.

Sou reconhecida aos muitos amigos que acompanharam e torceram por este trabalho. Em particular a Ana Lúcia Novelli e a Dra. Daisy Grisolia, pela generosidade e argúcia das críticas que tiveram a paciência de me dirigir.

Quero registrar a valiosa contribuição do Dr. Otelo Chino Jr. que me deu a oportunidade de conviver com os médicos da Associação dos Médicos do Hospital do Servidor Público Estadual.

Ao Dr. Sady Manoel Theodoro Ribeiro pela leitura dos seus textos médicos, atividade que foi profícua para o aprendizado da linguagem médica.

À Superintendência do IAMSPE, pelo fornecimento de dados e informações sobre os médicos e o Hospital do Servidor Público Estadual "Francisco Morato de Oliveira" e também aos médicos e pacientes que tiveram a generosidade e a paciência de responderem aos questionários.

Esse trabalho só foi possível graças à bolsa que me foi concedida pelo CAPES.

Aos funcionários da biblioteca do Conselho regional de Medicina, que foram incansáveis em ajudar-me na procura da documentação necessária.

Aos funcionários da AMIAMSPE, que me orientaram sobre o dia-a-dia dos médicos e do Hospital.

Ao amigo Artur Roman por sua contribuição inestimável, corrigindo qualquer desvio que eu pudesse ter.

A Sheila Saraiva e ao Júlio Bernardes que na pesquisa de campo ajudaram-me a recolher matéria prima para o trabalho.

Ao Haroldo Bevilácqua Fo e Niuton Tanaka pela viabilização dos dados e informações analisados neste trabalho. 
Aos professores Antonio Lima e Rinaldo Artes do Centro de Estatística Aplicada - CEA - USP.

A Jacinta de Sousa por dividir comigo a dura rotina do trabalho de casa.

Aos meus filhos pela compreensão da importância deste trabalho na minha vida e do tempo que precisei para fazê-lo, principalmente ao Victor que transportou para o computador centenas de dados e informações buscando ainda a estética necessária para apresentá-los.

Agradeço aos meus pais e irmãos ciente do muito que terei custado e que nunca poderei dimensionar.

A Deus por me ter dado a oportunidade e o discernimento. 


\section{Resumo}

A proposição dessa dissertação é demonstrar as características do processo comunicativo que acontece na relação médico-paciente, dentro do ambulatório, a fim de compreender sua função como mediadora da tensão existente entre as expectativas do paciente quanto ao atendimento idealizado e o serviço público realmente prestado na área da saúde em São Paulo.

Considerou-se pertinente analisar a questão da comunicação na saúde pública em São Paulo, usando como parâmetro o Hospital do Servidor Público "Francisco Morato de Oliveira", pertencente ao Instituto de Assistência Médica ao Servidor Público Estadual, o IAMSPE, por ser uma instituição que poderá fornecer dados sobre uma população de usuários, de serviços e de médicos.

Para isso foi preciso identificar as normas padrão de atendimento do hospital; a percepção do paciente sobre o médico e também de como acha que o médico 0 percebe, assim como do atendimento recebido pelo médico e pela Instituição. A percepção dos médicos sobre si mesmo, sobre o paciente e 0 atendimento oferecido por ele e pela Instituição. A noção de comunicação de ambos e a qualidade da comunicação nesta relação - procurando identificar os condicionantes que existem entre $o$ atendimento esperado e $o$ atendimento real.

Foi realizada uma pesquisa de campo com médicos e pacientes dos serviços mais representativos (pela importância e população atendida) e essa amostra mostrouse significativa, tanto pelos dados colhidos pelos questionários quanto pela observação feita pelos pesquisadores.

Os resultados dos dados e das informações colhidas são um retrato temporal dos papéis percebidos e vividos por médicos e pacientes no contexto de uma instituição de saúde pública na cidade de São Paulo. 


\begin{abstract}
This dissertation aims to study the characteristics of the communication process between the doctor and the patient within the clinic, so as to better understand it and analyze it as the mediation between patients' expectations - concerning idealized public health service - and the real public health service offered in São Paulo.

Therefore, communication in Hospital do Servidor Público "Francisco Morato de Oliveira" (a public hospital), a division of Instituto de Assistência Médica do Servidor Público Estadual - IAMSPE (Health Care System of the Public Sector), was analyzed. This institution provided valuable data and information about its patients, services and physicians.
\end{abstract}

To carry this research out, it was necessary to identify how the hospital provides its service, how the patient perceives the physician - and how he believes the physician perceives him -, how the patient perceives the services of the physician and of the Institution, and how the physicians perceive themselves, patients and the service offered both by himself/herself and by the Institution. The notion and the quality of the communication in this relationship were studied in order to identify the characteristics of both desired and real services.

A field research was carried out with physicians and patients of the most representative services (ranked by importance and by the size of the population served), and this portion of the population proved itself to be significant, because of both the data collected through questionnaires and the researchers' view point.

The results of the data and information collected are a timely picture of the roles perceived and lived by doctors and patients in the context of a public health care institution in the city of São Paulo. 


\section{SUMÁRIO}

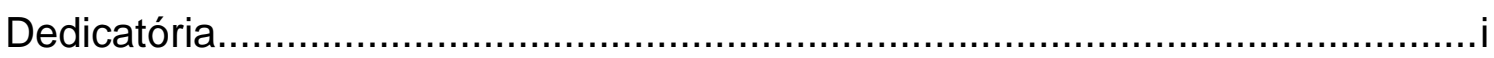

Agradecimentos...................................................................................

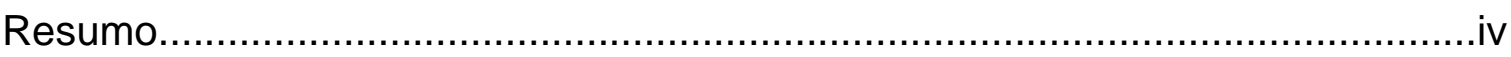

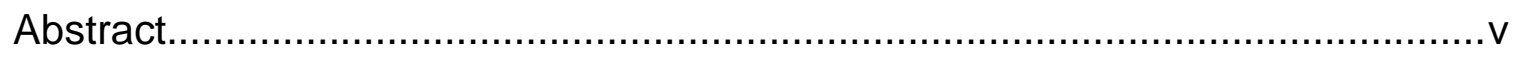

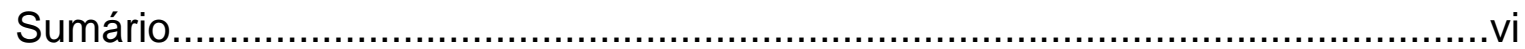

Capítulo I - Pressupostos para o estudo da comunicação no campo da saúde

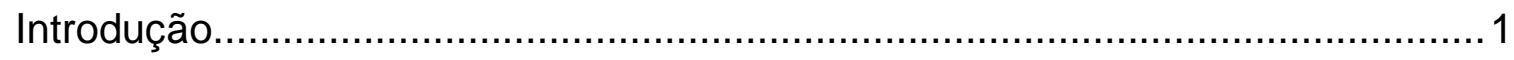

1. O estudo da comunicação e de públicos................................................. 4

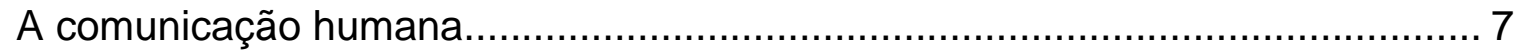

A comunicação e o seu contexto da significação.......................................... 9

2. Atitudes que interferem na comunicação........................................... 10

Interação com feedback.................................................................. 11

Percepção e avaliação pessoal........................................................ 12

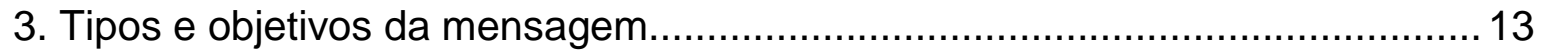

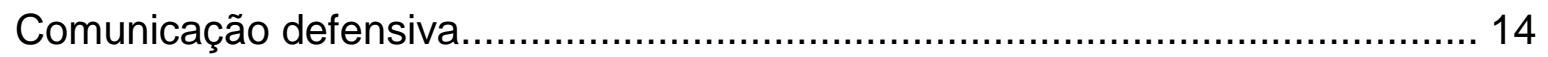

Interação e interexperiência em díades................................................. 15

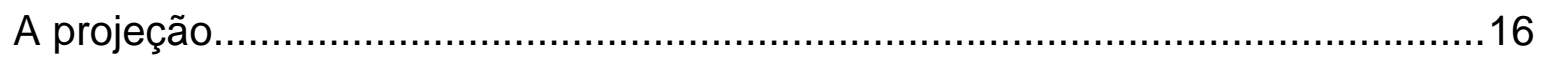

Capítulo II - Aspectos históricos, políticos e econômicos da saúde no Brasil

1. Histórico sobre os estudos da relação médico-paciente............................ 17

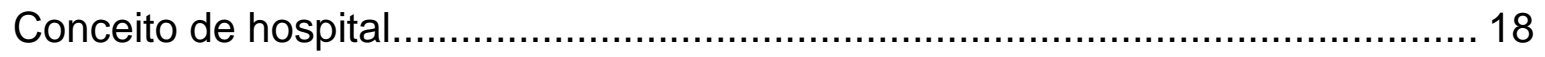

O hospital como organização.......................................................... 19

2. Conceito clássico e contemporâneo de médico....................................... 20

O ensino médico no Brasil....................................................................... 22

O médico brasileiro e o seu contexto de ação................................................. 24 
3. Conceito clássico e contemporâneo de paciente e de doença......................... 27

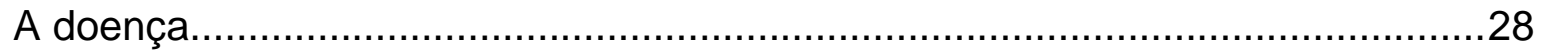

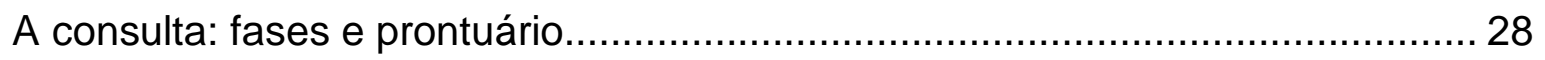

Fundamentos psicológicos da relação médico-paciente...................................... 31

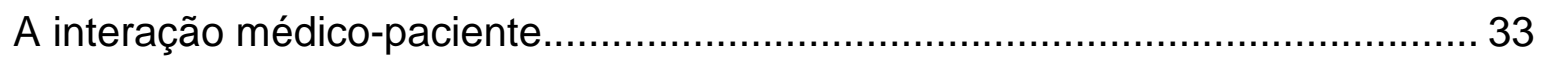

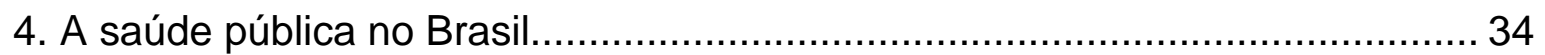

A visão dos governos federal e estadual à respeito da saúde............................... 36

O Hospital do Servidor Público Estadual "Francisco Morato de Oliveira"............. 40

Capítulo III - O cientificismo e o estudo

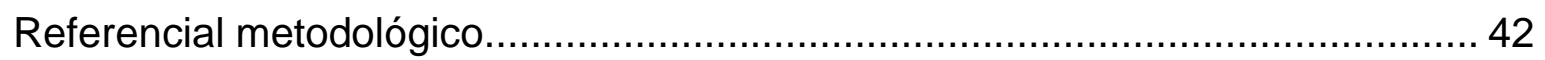

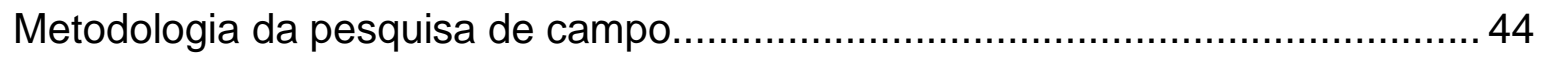

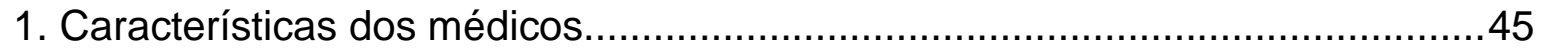

Características dos médicos quanto ao serviço................................................. 46

Perfil do médico do Hospital do Servidor público Estadual................................. 47

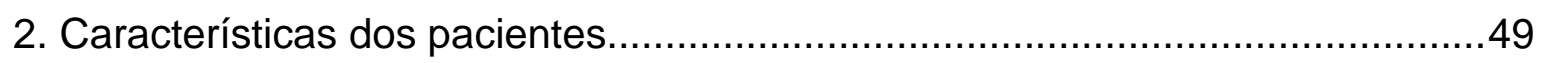

Perfil do paciente do Hospital do Servidor Público Estadual................................50

3. Serviços pesquisados, tanto para os médicos quanto para os pacientes..........51

Representatividade desses serviços............................................................ 51

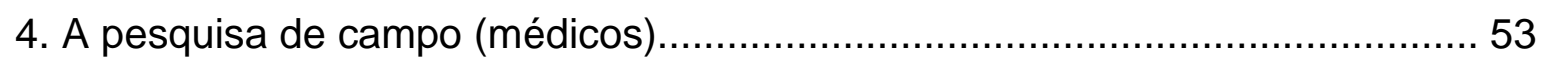

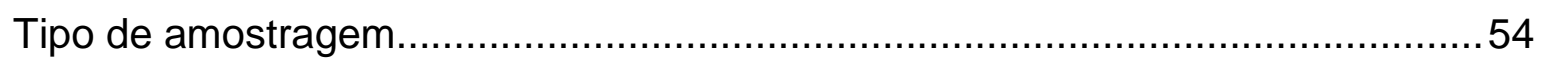

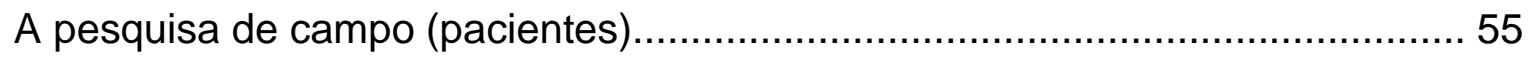

Critério para escolha dos pacientes.............................................................. 56

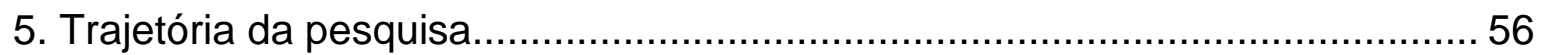

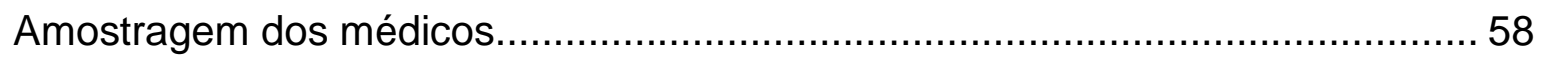

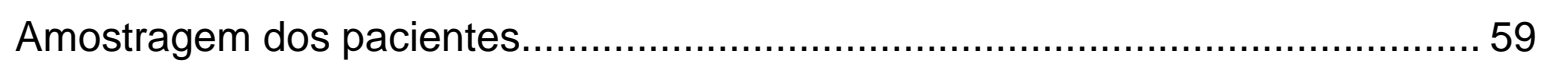

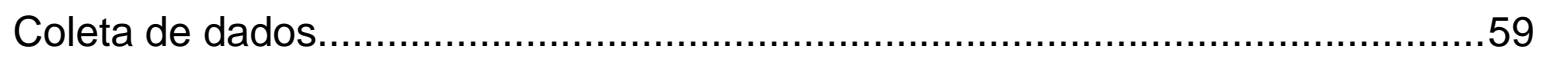

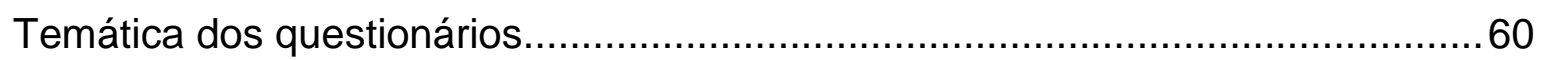

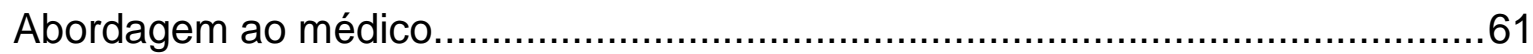


Abordagem ao paciente. 61

A equipe 61

6. Metodologia da análise dos dados do instrumento........................................... 62

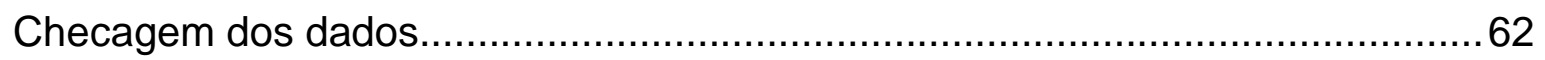

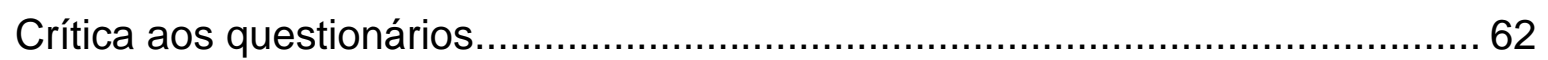

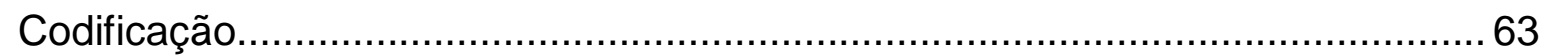

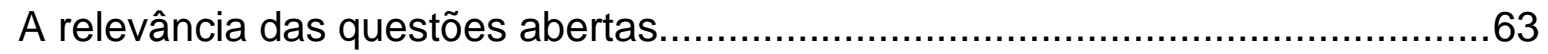

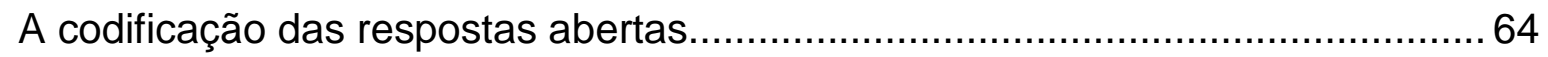

A relevância das perguntas fechadas.......................................................... 76

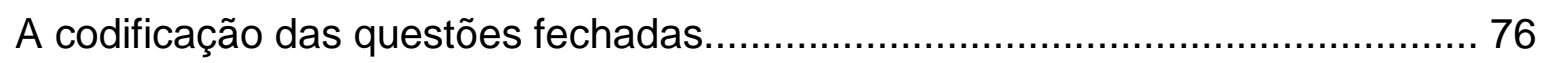

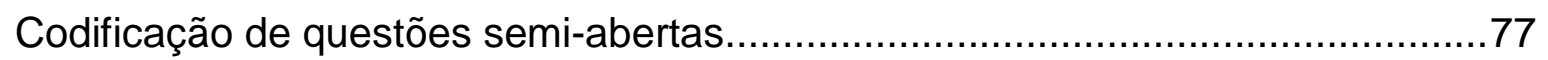

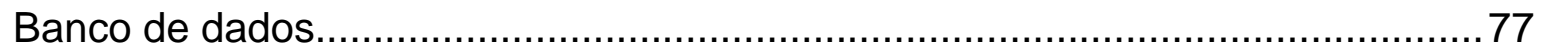

Capítulo IV - Resultados e conclusões

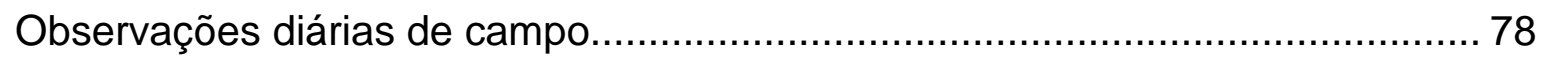

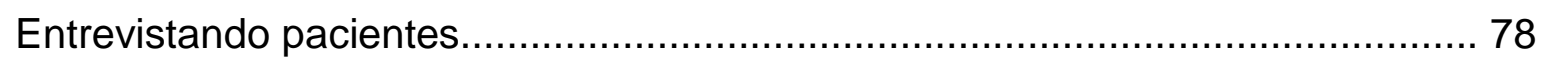

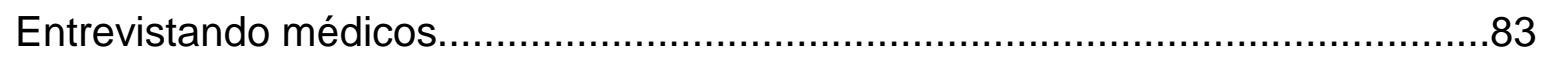

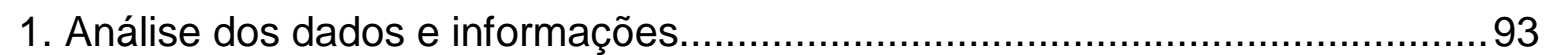

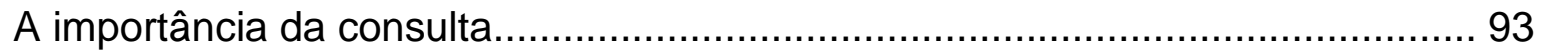

A percepção dos médicos sobre a consulta e o paciente..................................... 93

A compreensão do paciente na percepção do médico..........................................98

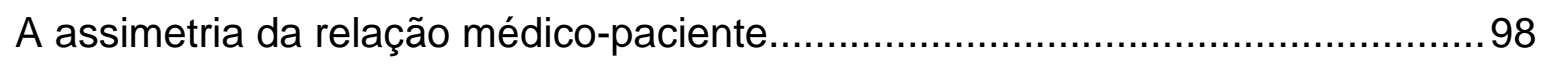

O paciente e sua percepção da consulta e do médico..........................................101

Comparando a percepção do médico com a do paciente.................................... 108

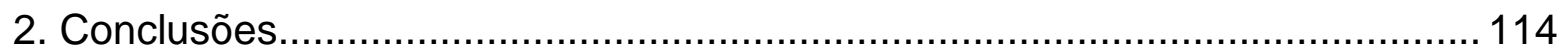

Quadros

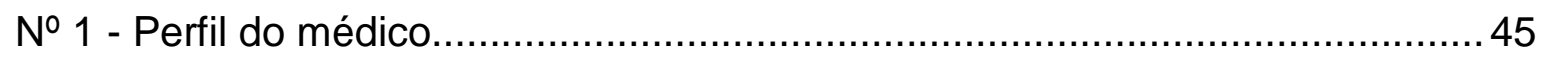

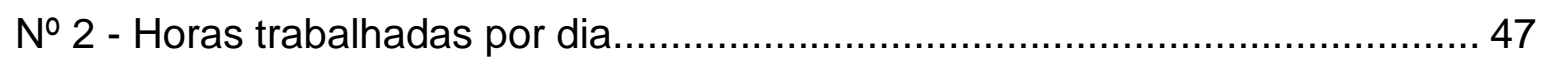

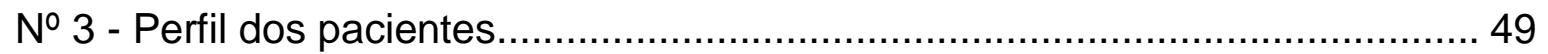




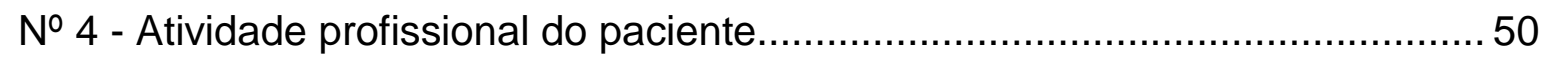

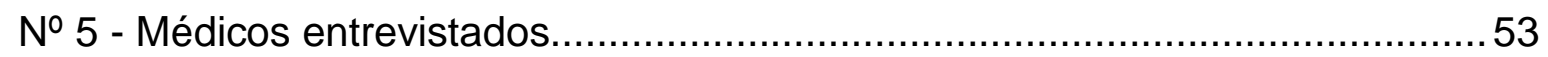

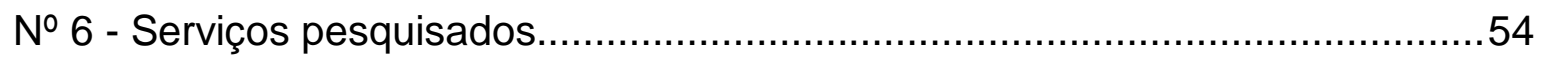

№ 7 - Número de pacientes entrevistados por serviço.........................................56

№ 8 - Número de médicos entrevistados por serviço..........................................58

№ 9 - Atributos para um bom atendimento ao paciente - respostas com

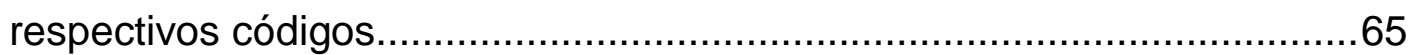

№ 10 - Atributos para um bom atendimento ao paciente, com a

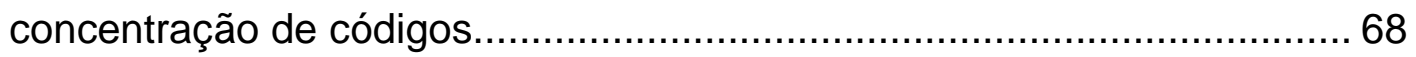

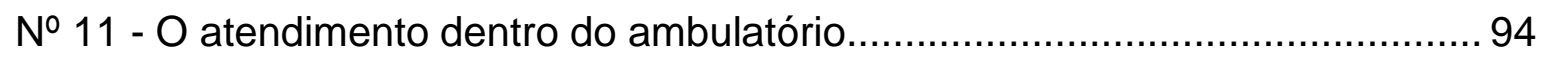

№ 12 - Número de pacientes entrevistados por serviço........................................101

№ 13 - Tempo de uso dos serviços do HSPE pelo paciente.................................102

№ 14 - Tempo de espera para o paciente ser atendido pelo médico......................103

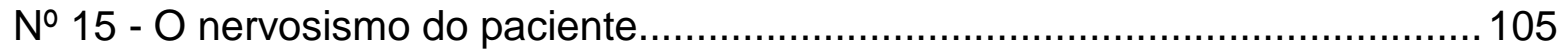

№ 16 - Atributos de uma boa comunicação...................................................... 149

№ 17 - O que o médico representa para o paciente............................................. 149

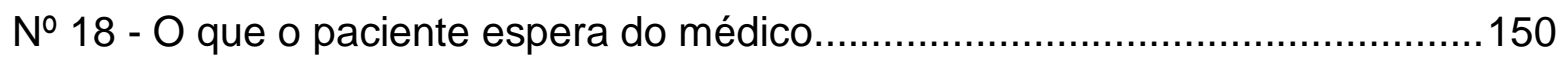

№ 19 - Atributos para um bom atendimento ao paciente..................................... 150

№ 20 - O que poderia ser feito para melhorar a comunicação do médico

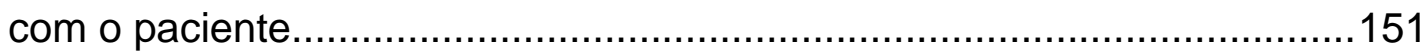

№ 21 - Material de apoio utilizado pelo médico..................................................151

№ 22 - O que falta ao médico para que o atendimento melhore do ponto de

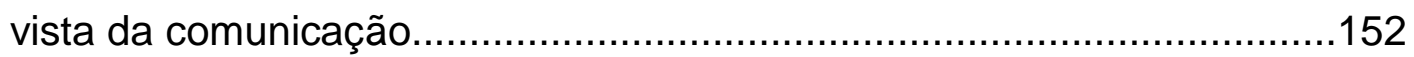

№ 23 - O que o médico considera uma comunicação clara...................................152

№ 24 - O que o paciente acha que é para o médico...........................................153

№ 25 - O que o paciente acha da comunicação entre o médico e o paciente

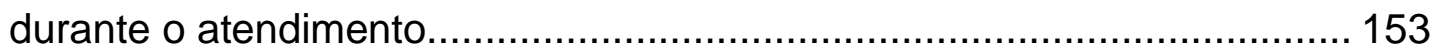

№ 26 - Se o paciente considera que uma comunicação clara sobre os procedimentos que ele tem que fazer ajudaria a melhorá-los.

№ 27 - Fatores que o paciente considera importante para haver uma boa comunicação entre o médico e o paciente.

№ 28 - O que poderia ser feito para melhorar a comunicação entre o médico e o paciente? 


\section{Anexos}

№ 1 Código de Ética Médica.................................................................... 124

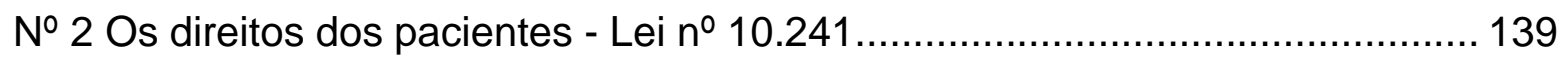

№ 3 Questionários para os médicos..................................................... 143

№ 4 Questionários para os pacientes........................................................... 146

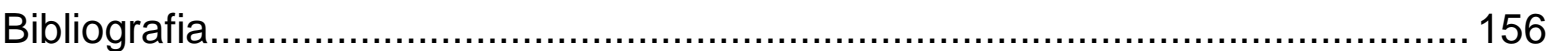




\section{Capítulo I - Pressupostos para o estudo da comunicação no campo da saúde}

\section{Introdução}

A moderna administração, influenciada pelas normas da International Standart Organization - ISO 9000, é dirigida cada vez mais para o desenvolvimento da qualidade de serviços e produtos. O foco é a obtenção de padrões de qualidade e excelência como fatores que agregam valores e vão se constituir no diferencial de competitividade no mercado.

Os profissionais em todos os níveis de produção são solicitados, cada vez mais, a exercitar sua capacidade de criação e invenção. Para isso, não basta contar com funcionários capazes de repetir mecanicamente suas tarefas. É preciso formar equipes de trabalho com pessoas motivadas e comprometidas com as metas da organização.

Para que isso seja conseguido, faz-se indispensável um sistema de comunicação eficiente que flua para todos os níveis hierárquicos da organização, informando e fazendo uso dessa informação para melhoria dos serviços prestados.

Trabalho e vida saudável estão vinculados estreitamente, por razões humanísticas e, atualmente, também porque as grandes organizações começam a reconhecer que quando investem em promoção de saúde, os gastos com tratamentos clínicos, previdência, prejuízos por acidentes de trabalho e absenteísmo diminuem de maneira significativa.

No Brasil, ao longo dos anos, a saúde tem sido desconsiderada, caracterizandose por atendimentos precários e dispendiosos de doenças que poderiam ser muitas vezes evitadas por bons programas de prevenção e promoção de saúde.

Os salários dos profissionais de saúde encontram-se entre os mais baixos do mercado para profissionais liberais, o que faz com que os mesmos assumam vários empregos. Como conseqüência, torna-se impessoal a relação com o paciente e fica diluída a responsabilidade profissional do médico, submetido a longas e cansativas jornadas de trabalho. 
Adoecer é um processo que obriga os indivíduos a rever as bases de sua vida. $A$ cura inclui o aprendizado. Assim sendo, os prestadores de serviços de saúde, como os hospitais, representam um papel fundamental na vida de todo cidadão, na medida em que são também responsáveis no esforço de restituir a esse cidadão condições psicológicas e físicas para que ele possa se reconhecer como cidadão e ser considerado como tal.

Nos serviços de saúde, seja ele público ou privado, a qualidade do vínculo e da comunicação são tão importantes quanto a disponibilidade de recursos e equipamentos. Para o bom andamento de qualquer tratamento é fundamental que haja uma comunicação eficiente entre o paciente e a equipe de saúde (médicos, enfermeiros, assistentes sociais, psicólogos, atendentes). É necessário, por um lado, que o paciente compreenda exatamente a extensão e a gravidade de sua doença, assim como as possibilidades e riscos inerentes a qualquer terapêutica, para que, orientado adequadamente possa tomar suas decisões, e por outro lado, que a equipe de saúde possa escutar com empatia as dificuldades objetivas e subjetivas vividas pelo paciente.

Esta pesquisa pretende contribuir para a melhoria da qualidade da comunicação na relação médico paciente na área da saúde pública, especificamente, a hospitalar. Foram estudados aspectos da comunicação humana, ressaltando as características do processo comunicativo que acontece na relação médico-paciente, dentro do ambulatório, a fim de compreender sua função na mediação da tensão existente entre as expectativas do paciente em relação ao atendimento idealizado e a realidade da prestação de um serviço público na área da saúde em São Paulo. Pretende-se demonstrar a percepção dos dois agentes sobre um modelo de comunicação e de alguns fatos que parecem apoiar tal modelo.

O Hospital do Servidor Público "Francisco Morato de Oliveira, pertence ao Instituto de Assistência Médica ao Servidor Público Estadual, o IAMSPE, foi usado como parâmetro, por ser uma instituição que poderá fornecer dados sobre uma parcela da população de usuários, de serviços e de médicos.

As implicações interdisciplinares do tema estão refletidas na maneira da apresentação do estudo. 
No capítulo I estão contidos os pressupostos para o estudo da comunicação no campo da saúde, abordando os públicos, a comunicação humana, o seu contexto de significação, atitudes que interferem na comunicação, tipos e objetivos de mensagem, a comunicação defensiva, interação e interexperiência em díades e a projeção.

O capítulo II trata dos aspectos históricos, políticos e econômicos da saúde no Brasil, destacando o ensino médico, o contexto de ação desse profissional, as fases da consulta; o prontuário; os fundamentos psicológicos da relação médico-paciente; a visão dos governos federal e estadual e o local da pesquisa de campo: o Hospital Público Estadual "Francisco Morato de Oliveira".

O capítulo III contém o referencial metodológico, a metodologia da pesquisa de campo; as características e o perfil dos médicos e pacientes; os serviços pesquisados e sua representatividade; a pesquisa de campo e a metodologia da análise dos dados e das informações do instrumento.

O capítulo IV apresenta os resultados e as conclusões, com as observações diárias de campo; a análise dos dados e informações; a importância da consulta; a percepção dos médicos sobre a consulta e o paciente; a compreensão do paciente na percepção do médico; a assimetria da relação médico-paciente; o paciente e sua percepção da consulta e do médico e a comparação de ambas as percepções.

Os resultados dos dados e informações colhidas são um retrato temporal dos papéis percebidos e vividos por médicos e pacientes no contexto de uma instituição pública na cidade de São Paulo.

"O homem vê este mundo através de padrões ou gabaritos transparentes que criou e depois tenta adaptá-los às realidades que compõem o mundo".

George Kelly 


\section{O estudo da comunicação e de públicos}

Anzieu e Martin ${ }^{1}$, definem a comunicação como um conjunto dos processos físicos e psicológicos através do qual se operacionaliza a relação (interação) de uma ou de várias pessoas - o(s) emissor(es) - com outra(s) pessoa(s) - o(s) receptor(es) no intento de atingir determinadas metas.

Segundo esses autores, pode-se estudar a comunicação segundo duas perspectivas: A primeira seria o aspecto formal da comunicação (transferência de informação quantificável). Onde o emissor, conforme seu objetivo, encaminha a mensagem que tende a atingir o outro. Esta percorre uma canal (visual, acústico e tátil) e impressiona o destinatário, promovendo efeito, cuja relevância depende da compreensão da mensagem e de sua representação para ele.

Nesse processo podem ocorrer problemas relativos: ao emissor, decorrentes da qualidade e pertinência de sua codificação; ao receptor, relativos à percepção correta dos sinais e à capacidade de decodificação; ao canal de comunicação, parasitas e desperdícios físicos que comprometem a quantidade e a qualidade de informação transmitida (ruídos); à retroalimentação, (feedback) ou regulação quase automática do emissor mediante o controle de seus efeitos no receptor.

A segunda seriam os aspectos psicossociológicos da comunicação. Neste caso, a comunicação é encarada como contato entre duas ou mais personalidades, envolvidas numa mesma situação e que debatem significações. Esses três fatores influem na emissão e recepção de mensagens e devem ser considerados: personalidades - os comunicantes têm história pessoal, sistema de motivações, estado afetivo, nível intelectual e cultural, marca de referência, status social e papéis psicossociais; situação comum - a comunicação propicia a ação do indivíduo sobre outros, num contexto definido, caracterizando-se como um meio para transformar este contexto; significações - os elementos da comunicação ssão essencialmente símbolos, o que faz com que esta sirva não só para passar informação como também

\footnotetext{
${ }^{1}$ ANZIEU, D. \& MARTIN, J. Y. La dinámica de los grupos pequeños. Buenos Aires, Kapelusz, 1971, p. 111-128.
} 
promover troca de significações. Assim, se a atenção é dirigida à forma literal das verbalizações, o conteúdo significativo da mensagem resultado anulado.

Os objetivos da comunicação são informar, convencer, mudar uma opinião, fazer agir, calar e expressar sentimentos, instruir, atuar sobre o equilíbrio emocional e a saúde psíquica, induzir sentimentos, fatores que influem sobre o conteúdo e o estilo da mesma.

Os interlocutores podem, ambos, apresentar necessidade de comunicar-se ou um deles pode se negar a entrar em comunicação. A atitude para a comunicação será tanto mais satisfatória quanto mais os comunicantes pensem segundo o mesmo universo simbólico e possuam os mesmos referenciais.

Foram abordados aspectos da comunicação, é necessário então a busca de um referencial teórico sobre os agentes comunicantes. O referencial sobre "público" demonstrará os tipos que são inerentes às organizações.

A palavra público, originária do latim publicus, significa depois da adolescência. No nosso estudo seu significado pode ser idade adulta. O termo público remete ao agrupamento de pessoas que alcançaram a maturidade, sua característica fundamental é exatamente a predominância das considerações racionais em relações às emoções, em face de controvérsias em discussão. Pode-se dizer que o público é formado por pessoas adultas, que pensam e refletem sobre os problemas colocados.

Segundo Andrade ${ }^{2}$, tradicionalmente os públicos de uma organização podem ser classificados pelo critério geográfico que dimensiona as distancias do público a respeito do centro de poder da organização.

- Interno: são pessoas que fazem parte da vida diária da organização (diretores, funcionários, familiares da diretoria e funcionários);

- Misto: são pessoas que mantém determinados tipos de vínculos ou interesses comuns com a empresa, mas sem estarem presentes fisicamente vivendo a rotina organizacional (fornecedores, acionistas, vendedores autônomos, representantes, distribuidores, etc.)

\footnotetext{
${ }^{2}$ ANDRADE, Cândido Teobaldo de Souza. Para entender Relações Públicas. Ed. Loyola, São Paulo, 1988.
} 
- Externo: são as pessoas que não trabalham na organização e não têm vínculo direto e que podem ou não conhecer/consumir os produtos ou serviços das empresas (comunidade vizinha, governo, consumidores, bancos, igreja, meios de comunicação, concorrência, comércio etc.)

Essa classificação tornou-se muito rígida frente às mudanças enfrentadas pelas organizações no ambiente atual.

Seguindo uma nova perspectiva Grunig e Hunt $^{3}$, apresentam a seguinte classificação:

- Não público: pessoas que não mantém nenhum vínculo com a organização e esta não causa nenhuma conseqüência no público.

- Latente: quando os membros de um grupo sentem-se afetados por conseqüências da organização, porém não conseguem detectar claramente qual é o problema ou a causa.

- Consciente: quando o público reconhece que o problema existe e começa a se conscientizar dele e de suas causas.

- Ativo: quando o grupo organiza-se para discutir o problema e surgem as propostas de solução para resolver o problema detectado.

De acordo com esta proposição, a comunicação vai atuar segundo as necessidades de informação de cada público específico em um dado momento. $O$ modelo possibilita maior flexibilidade às pessoas que compõem o público, pois, a partir de uma situação determinada, podem ser classificados de maneira diversa.

$\mathrm{Na}$ perspectiva concreta de análise do sistema de comunicação de uma organização hospitalar pública, a classificação dos públicos apresentada por Grunig e Hunt mostra-se interessante na medida em que não segmenta os usuários e os médicos de maneira rígida, e permite uma integração destes atores de acordo com as situações vividas.

${ }^{3}$ GRUNIG, James E.; GRUNIG, Larissa A. Excellence in public relations and communication management. Lawrence Erlbaum Publisher, EUA, 1992. 


\section{A comunicação humana}

Como o estudo trata da comunicação humana, faz-se míster entendê-la e a percepção de alguns autores colaboram nesse sentido.

Para Mortesen ${ }^{4}$ :

"A tradução das línguas humanas é freqüentemente associada à capacidade de compreender os elos essenciais entre uma língua (ou código) e outra. Considera-se tradutor aquele que consegue identificar uma palavra ou uma mensagem em relação a uma série correspondente de termos lingüísticos diferentes, estabelecendo relação entre, digamos, o inglês e o espanhol. O que não foi compreendido inteiramente ainda é que a atividade da tradução também ocorre no uso cotidiano da língua convencional. Traduzir significa transformar, impor a própria posição interpretativa na maneira como as coisas são apreendidas. Portanto, a tradução ocorre todas as vezes que se tenta aplicar a própria estrutura referencial em alguma forma de experiência humana. Tal desempenho não exige troca de palavras nem tampouco qualquer reconhecimento da presença de outra pessoa. O conceito de tradução se refere antes a uma série de ações sutis e complexas sustentada pela pura disposição de conceder significação aos eventos humanos."

Ou autor diz ainda que, para ocorrer, a tradução deve ser apoiada pela comunicação humana. Nos ambientes em que existem relações frontais, um ato comunicativo implica uma fonte que emite uma mensagem através de um canal para um receptor, cujas reações fornecem feedback para a fonte de informação inicial. O conceito de tradução humana pode ser compreendido como uma complexa negociação entre pessoas e seus ambientes.

Ainda para Mortesen ${ }^{5}$, partindo-se de um ponto de vista comunicativo, a mensagem pode ser definida como qualquer unidade de informação que funciona como

\footnotetext{
${ }^{4}$ MORTENSEN, C. David. Teoria da Comunicação. Wisconsin, Mosaico, 1980, p. 11.

${ }^{5}$ MORTENSEN, C. David, op. cit., p. 12.
} 
um elo entre pessoas que coexistem em estado de interação. Os elos informativos teriam que ser analisados sob a perspectiva dos contextos das implicações emotivas ou afetivas.

Seria enganoso analisar a troca de mensagens da mesma forma como analisarse-ia a troca de algum objeto físico. Uma mensagem não é um objeto que existe independentemente das experiências das pessoas que nela trabalham; uma mensagem não possui qualquer significação até o momento em que ocorra alguma forma de tradução.

Tampouco pode-se concluir que a tradução ocorra sem quebras ou rupturas. $O$ sistema nervoso humano só pode lidar com uma quantidade limitada de informação, e o campo de consciência de uma pessoa isolada dificilmente pode ser considerado como amostra objetiva da informação potencialmente disponível.

A continuidade da tradução depende da manutenção de duas espécies distintas, segundo Mortesen, embora correlacionadas, de atividades interpretativas. Uma é a decodificação; a outra a codificação. A decodificação se refere à lógica ou aos métodos utilizados para a interpretação do comportamento de outra pessoa, e a codificação remete aos padrões utilizados para a criação do próprio desempenho. Decodifica-se quando se escuta ou se observa alguém falar, e codifica-se quando se está transmitindo ativamente informações para alguém. Tanto a decodificação como a codificação implicam lógicas pessoais que auxiliam a regular e controlar o desempenho.

Os canais de comunicação operam em todos os níveis da sociedade; o acesso a um canal facilita a interação entre indivíduos, grupos, organizações e audiência em massa.

O conceito de feedback salienta os aspectos dinâmicos e envolventes do processo de comunicação. Quer seja positivo, negativo ou indiferente, o feedback afeta profundamente o fluxo de informação. De maneiras diversas, que divergem tanto quanto as personalidade individuais, o feedback altera a textura da informação humana e os fluxos de reações que são a esta atribuídos.

A tradução depende da capacidade de percepção precisa de outras pessoas, não são um registro passivo de objetos e eventos; constituem uma elaborada criação 
de significados. Os dados sensoriais estão constantemente sendo selecionados, classificados, transformados e registrados em padrões de interpretação e importância singulares. Os limiares sensoriais, as perspectivas pessoais, as expectativas, todos são úteis para ajudar a destacar o que é significativo na experiência de um indivíduo.

\section{A comunicação e o seu contexto da significação}

Para Barnlund ${ }^{6}$ quando a criança atinge a maturidade, ela gradualmente assimila um quadro do mundo que habita e seu lugar dentro dele. As orientações gerais - confiança ou suspeita, afeto ou hostilidade - são aprendidas através da comunicação com outras pessoas significativas. O sucesso ou fracasso contribui de alguma maneira para o seu acúmulo de suposições acerca do mundo e da maneira como esse funciona. Tais predisposições cognitivas são assimiladas inconscientemente, com a maioria das pessoas estando vagamente cientes dos seus importantes efeitos. E, segundo Roger Harrison ${ }^{7}$ :

"Constituem o equipamento de sobrevivência mais importante que possuímos. Desta maneira, não são os eventos propriamente ditos, mas sim a maneira como os homens interpretam tais eventos que determina o que vêem, como sentem, como pensam e como reagem."

Para Barnlund ${ }^{8}$ :

"O homem não é receptor passivo, mas um agente ativo que dá sentido às sensações. A significação que qualquer situação adquire é conseqüência tanto do que o perceptor Ihe acrescenta como da matéria prima que recebe. Termos tais como "construções pessoais", "esquemas sociais" e "planos perceptivos" têm sido utilizados para

\footnotetext{
${ }^{6}$ BARNLUND, Dean C. Comunicação: o contexto da mudança. In: MORTENSEN, C. David. Teoria da Comunicação. Wisconsin, Mosaico, 1980, p. 16.

${ }^{7}$ HARRISON, Roger. Defenses and the need to know. In: LAWRENCE, Paul; SEILER, George V. Organizational Behavior and Administration. Homewood, Irwin and Dorsey, p. 267.

${ }^{8}$ BARNLUND, Dean C. Comunicação: o contexto da mudança. In: MORTENSEN, C. David. Teoria da Comunicação. Wisconsin, Mosaico, 1980, p. 16.
} 
identificar os processos cognitivos por meio dos quais o homem torna sua experiência inteligível."

Tais vieses perceptivos, tomados conjuntamente, constituem o chamado mundo suposto do indivíduo. O mundo que os homens põem em suas cabeças é o único mundo que conhecem. É este mundo simbólico, e não o mundo real, que comentam, disputam, discutem e zombam. É este mundo que os impele a cooperar ou a competir, a amar ou a odiar.

Os cientistas behavioristas, Hastorf e Cantril ${ }^{9}$ concluíram: é impreciso e enganoso dizer que pessoas diferentes têm atitudes diferentes em relação a mesma "coisa". Pois a "coisa" não é a mesma para pessoas diferentes. Comportamo-nos de acordo com o que acrescentamos ao momento, e o que cada um de nós acrescenta ao momento é mais ou menos único. E, excluindo essas significações que acrescentamos ao momento, os acontecimentos à nossa volta não passam de ocorrências sem significado, "inconseqüentes".

Assim toda percepção é necessariamente pessoal e incompleta. Ninguém jamais vê tudo, pois cada um abstrai de acordo com sua experiência passada e desejos incipientes.

\section{Atitudes que interferem na comunicação}

As pesquisas de Leavitt e Mueller ${ }^{10}$ ilustram algumas das dificuldades que caracterizam a comunicação. Pessoas tentando dar até mesmo a mais simples das instruções descobriram que suas ordens foram executadas imperfeitamente, que os erros de interpretação não poderiam ser corrigidos e que tal condição produzia queda moral. A causa de tal queda foi a de receber informações confusas ou complicadas e ser incapaz de decifrá-las.

\footnotetext{
${ }^{9}$ HASTORF, Albert; CANTRIL, Hadley. They Saw a Game: a Case Study. Journal of Abnormal and Social Psychology 49, 1954, p. 129-134.

${ }^{10}$ LEAVITT, Harold; MUELLER, Ronald. Some Effects of Feedback on Communication. Human Relations 4, 1951, p. 401-410.
} 
Para Barnlund ${ }^{11}$ é também provável o aparecimento de uma atmosfera ameaçadora em contatos em que um dos comunicantes mantém uma distância emocional considerável, os que são friamente objetivos ou se recusam a expor seus próprios sentimentos são passíveis de serem vistos com olhos desconfiados. Ser tratado como uma série de fatos ou como um problema a ser resolvido, ao invés de um ser humano, dificilmente contribui para um relacionamento interpessoal.

O entendimento entre homens é facilitado quando há a disposição para o envolvimento com a outra pessoa. Significa considerá-lo um valor em si mesmo, ao invés de um meio para outro valor, valorizar sua experiência e suas necessidades e, acima de tudo, considerar e explorar seus sentimentos.

\section{Interação com feedback}

$F_{\text {Feedback }}^{12}$, no caso da interação humana, se refere ao processo de ajuste de um comportamento comunicativo de forma a observar as influências percebidas desse comportamento sobre o ouvinte.

O termo feedback não diz respeito a nenhum catálogo comportamental do ouvinte, mas sim a uma relação entre o comportamento do falante, a reação do ouvinte e o efeito dessa reação sobre o comportamento posterior do falante. Assim, a reação do ouvinte não constitui feedback se não afeta o comportamento subsequente do falante ${ }^{13}$.

Todas as vezes que um falante altera seu comportamento de fala, adaptando-se de uma forma ou de outra à reação de seu ouvinte, pode-se dizer que está reagindo ao feedback. Introduzir possibilidade para o feedback na interação humana é melhorar em muito a qualidade dos contatos entre os homens; assim cada parceiro da interação pode não apenas influenciar e ser influenciado pelo outro, mas também o comportamento de cada um será condicionado pelo outro.

\footnotetext{
${ }^{11}$ BARNLUND, Dean C., op. cit., p. 23.

${ }^{12}$ CLEVENGER, Theodore; MATTHEWS, Jack. Feedback. In: MORTENSEN, C. David. Teoria da Comunicação. Wisconsin, Mosaico, 1980, p. 55.

${ }^{13}$ CLEVENGER, Theodore; MATTHEWS, Jack, op. cit., p. 53.
} 


\section{Percepção e avaliação pessoal}

Pode-se dizer que interagimos, não com indivíduos ou objetos, mas com a imagem que fazemos deles. Afinal, não os tratamos como coisas físicas, mas sim como objetos, aos quais conferimos identidade e significados. Nossas atitudes em relação aos mesmos fundamentam-se nos significados a que nos remetem e nas influências que exercem sobre nossos diversos planos de ação.

O processo de percepção de objetos não representa um registro passivo de eventos externos. Durante todas as fases do processo, o observador se intromete ativamente no fluxo de dados. Portanto, para se compreender o que é visto é preciso compreender o próprio observador, assim como o que realmente está acontecendo.

Para Simons e McCall ${ }^{14}$ :

"À medida que outras pessoas e objetos são observados e interpretados quanto ao significado que para nós possuem, chega-se à conclusão de que nossas escolhas e classificações refletem apenas parcialmente a verdadeira natureza das coisas. Assim como escolhemos os significados, também os criamos; e há uma grande categoria de objetos sociais que existem apenas como significados criados e coletivamente compreendidos."

Para se entender a avaliação, feita pelo indivíduo, das pessoas e situações com que se depara, deve-se analisar detalhadamente este processo de percepção e de recodificação, no qual, além de se perderem informações, surgem as informações falsas.

Além dos limites sensoriais as percepções também são limitadas pela mera perspectiva ou posição da qual se observa. O panorama é basicamente determinado pelo ponto de onde se olha, portanto, unilateral.

\footnotetext{
${ }^{14}$ SIMONS, George J.; McCALL, J.L. Percepção e avaliação social. In: MORTENSEN, C. David. Teoria da Comunicação. Wisconsin, Mosaico, 1980, p. 72.
} 
O viés da perspectiva, resultante das posições sociais é geralmente mais complexo e difícil de ser evitado do que os efeitos da posição física no espaço. A precisão da percepção diminui na medida em que aumenta a distância social.

\section{Tipos e objetivos da mensagem}

De certo modo, toda comunicação representa um processo transmissivo de informações, as quais são recebidas por outra pessoa. Porém, à medida que se constata a infinidade de maneiras pelas quais pode se descrever o tipo e o objetivo da mensagem enviada, a categoria comunicativa de transmissão-recepção parece insuficiente. Aqui estão alguns tipos de mensagem catalogadas por Condon ${ }^{15}$, que são importantes para o estudo:

Quando se fala alguma coisa e algo acontece em função daquela fala, os comentários possuem caráter instrumental. Alguns enunciados possuem caráter instrumental, ou na intenção ou no efeito, mas não são expressos como tal. Por exemplo, se você deseja que alguém the passe o sal, pode fazer o pedido diretamente (instrumental) ou aludir ao fato de a comida estar insossa (informação transmissiva);

> A comunicação afetiva constitui o processo em que a mensagem equivale aos sentimentos emotivos que o locutor nutre em relação ao ouvinte. Cumprimentos, elogios e lisonjas - assim como hipocrisia e interrupções bruscas -, todos constituem elementos dessa categoria. A linguagem afetiva é também convincente. Em muitos casos, não se consegue obter nada de uma pessoa a ser por meio de vias indiretas. Prefere se fazer aquilo que se julga querer fazer, e não aquilo que se ordena ou pede que se faça;

> A fé no poder mágico das palavras existe em todas as culturas e assume a forma de superstições, pragas de caráter instrumental, dogmas religiosos e manifestações secundárias de racionalização do desejo. A fé em que o pensar e o dizer palavras podem exercer alguma influência sobre o elemento a que se referem já equivale a por em prática a função de magia da comunicação;

\footnotetext{
${ }^{15}$ CONDON JR., John C. Quando os homens se comunicam entre si. In: MORTENSEN, C. David. Teoria da Comunicação. Wisconsin, Mosaico, 1980, p. 189-200.
} 
$>$ No ato comunicativo, os indivíduos sempre trocam algo mais do que simplesmente palavras. Observa-se também pistas indicativas da maneira pela qual as palavras podem ser interpretadas. A essa interpretação sobre a comunicação dá-se o nome de pistas metacomunicativas. Tais pistas podem reforçar o significado das palavras, desviar a atenção do ouvinte quanto ao enunciado da mensagem, ou mesmo contradizer com aquele discurso. Quando as pistas diferem das palavras, o ouvinte sente dificuldades em aceitar a mensagem.

\section{Comunicação defensiva}

Gibb $^{16}$ define o comportamento defensivo como aquele que se manifesta quando um indivíduo observa ou pressente uma ameaça dentro de um grupo. Estimular uma atitude de defesa implica impedir que o ouvinte se concentre na mensagem. Quando se colocam na defensiva, os comunicadores transmitem pistas de valor, motivação e afetos múltiplos e os receptores que assumem a mesma atitude distorcem tudo aquilo que recebem. À medida que uma pessoa se coloca mais e mais na defensiva, torna-se cada vez menos capaz de apreender, com exatidão, as motivações, valores e emoções do emissor.

Um indivíduo provoca atitudes de defesa ao transmitir a outrem um sentimento de superioridade, seja em termos de posição, poder, riqueza, capacidade intelectual, características físicas, seja de outras maneiras. Neste caso, qualquer que seja o elemento responsável por despertar sentimentos de inadaptação, ele induz o receptor a se concentrar sobre a carga afetiva do enunciado, em detrimento dos fatores cognitivos, o destinatário reage recusando-se a ouvir a mensagem, esquecendo-se dela, competindo com o emissor ou invejando-o.

Quando transmite a impressão de nutrir sentimentos de superioridade, o indivíduo comunica que não está disposto a encetar um relacionamento visando à resolução de problemas comuns; que provavelmente não deseja obter feedback; que não necessita de auxílio e/ou que se sentira propenso a tentar minimizar o poder, status ou mérito do ouvinte.

\footnotetext{
${ }^{16}$ GIBB, Jack R. Comunicação defensiva. In: MORTENSEN, C. David. Teoria da Comunicação. Wisconsin, Mosaico, 1980, p. 225.
} 


\section{Interação e interexperiência em diádes}

Quais os fatores que provocam a existência de interpretações diametralmente opostas? Pode se afirmar que as interpretações se baseiam no aprendizado passado. Principalmente o adquirido dentro de um recesso familiar (ou seja, com nossos pais, irmãos e outros parentes) - assim como o obtido na grande sociedade cujo caminho percorremos. Em segundo lugar, o ato propriamente dito é interpretado de acordo com o contexto em que se encontra ${ }^{17}$.

O que acontece quando duas pessoas não concordam com o significado a ser atribuído a um ato específico? Para Laing e $\operatorname{Lee}^{18}$ :

"Sem sombra de dúvida, um processo bastante complexo. Se o ato comunicativo estiver em um nível ótimo, elas compreenderão que possuem diferentes interpretações do ato, além de estarem conscientes de que ambas compreendem que suas interpretações não são consideradas coincidentes. Isto posto, podem passar a discutir a validade ou não validade de se mudar o ato em questão no futuro. Essa discussão pode assumir diversas formas:

Ameaça: faça isso, senão...

Indução: faça isso, por favor.

Suborno: se você fizer isso, eu, em troca,...

Persuasão: acharia muito bom se você fizesse isso, porque...."

Todavia, sempre que houver discordância de uma relação entre dois seres humanos, não raro, observa-se mal-entendidos e não percepções dos mal-entendidos. Tais fatores podem possuir caráter intencional, ou seja, constituírem uma mera tentativa de ignorar o ponto de vista do interlocutor ou, então, representarem um involuntário desprezo pelo ponto de vista contrário. A ruptura do ato comunicativo está presente em ambos os casos.

\footnotetext{
${ }^{17}$ LAING, R.D.; PHILLIPSON, H.; LEE, A.R. Interação e interexperiência em diádes. In: MORTENSEN, C. David. Teoria da Comunicação. Wisconsin, Mosaico, 1980, p. 386.

${ }^{18}$ LAING, R.D.; PHILLIPSON, H.; LEE, A.R., op. cit., p. 387.
} 


\section{A projeção}

Projeção é uma forma de ação dirigida à própria experiência que o indivíduo possui do outro, constituindo o assim chamado "mecanismo mental"19. Esse termo é bastante enganoso, pois não é nem mental nem tampouco mecânico. Trata-se de uma ação cujo objetivo intencional é a própria experiência que o indivíduo possui do outro. Tais processos compartimentais foram identificados graças aos esforços da psicanálise.

Segundo Laing e Lee ${ }^{20}$ :

"Projeção sem sombra de dúvida, constitui uma tática comportamento que se reveste da mais alta importância, podendo operar de diferentes maneiras em um sistema interpessoal; para todos os efeito, contudo, representa uma dentre uma série de ações cujo objetivo não é a experiência que o outro possui de mim, mas sim a experiência que possuo do outro. Desnecessário é dizer, tal mecanismo, em uma segunda instância, poderá vir a influir na experiência que outro possui de mim.

A projeção é um modo pelo qual influenciamos o outro ao, paradoxalmente, não agirmos diretamente sobre ele como um indivíduo real, mas sim sobre a experiência que dele possuímos. Porém, se transmito ao outro a maneira como o capto através de minha experiência de sua pessoa, certamente estarei influenciando-o.

A projeção pura e simples nada nos informa sobre o outro, remetendo-nos apenas a uma área de interação didática, ou seja, o modo como você trabalha a experiência que possui de mim ou o modo como trabalho a experiência que possuo de você. Todavia como bem sabemos, a projeção influenciará outra áreas, assim como por elas será influenciada, visto que o seu modo de me captar se inter-relaciona com o modo como ajo em relação a você, e assim por diante."

\footnotetext{
${ }^{19}$ LAING, R.D.; PHILLIPSON, H.; LEE, A.R., op. cit., p. 389.

${ }^{20}$ LAING, R.D.; PHILLIPSON, H.; LEE, A.R., op. cit., p. 390-391.
} 


\section{Capítulo II}

\section{Aspectos históricos, políticos e econômicos da saúde no Brasil}

\section{Histórico sobre os estudos da relação médico-paciente}

Foi na Inglaterra que Michael Balint, em 1950, deu início ao estudo científico da relação médico-paciente, através de reuniões de clínicos gerais, interessados no conhecimento da intimidade dessa relação. Este trabalho do grupo Balint teve grande repercussão e deu origem a várias publicações no mundo.

Balint focalizou vários aspectos da relação médico-paciente e da psicoterapia aplicada à Medicina. Ele via o médico como sendo o remédio mais usado pelo paciente, assim precisava ser conhecido em sua posologia, toxidade e efeitos colaterais, como os demais medicamentos ${ }^{21}$. Ressaltou, também, a importância do profissional considerar o paciente como uma pessoa (não um órgão doente), confirmando que o desprezo pelos aspectos psicológicos do paciente diminui as possibilidades de debelar o processo mórbido, ainda na fase inicial. E que, se o médico não aceita ou não entende os sintomas apresentados pelo paciente, este tende a intensificá-los, no intuito de fazer-se compreender.

Balint discorreu sobre procedimentos utilizados na prática médica, restritivas ao contato com o paciente e à percepção dos problemas do mesmo. Entre esses procedimentos está o rodízio nos atendimentos hospitalares.

O grupo Balint elaborou um método de atendimento psicológico, durante a consulta clínica comum. Este atendimento, cuja duração é de seis a dez minutos, serve aos casos em que entrevistas longas não são possíveis. Propõe que o médico, inteiramente voltado para o paciente, tenha com ele um contato muito íntimo, o que favorece o flash, momento de intensa comunicação mútua, em que ocorre um insight simultâneo sobre determinada problemática do paciente.

Waltzlawick, et al (1973), pesquisadores do Instituto Mental de Palo Alto na Califórnia, editaram um estudo dos padrões, patologias e paradoxos da interação, onde são discutidos os efeitos da comunicação, principalmente nos distúrbios de

\footnotetext{
${ }^{21}$ BALINT, E.; NORELL, S. Seis minutos para o paciente. São Paulo, Manole, 1976, p. 23.
} 
comportamento, os quais são considerados mais como uma reação comunicativa a um dado evento do que sintoma de doença mental deste ou daquele indivíduo.

Estes pesquisadores enfatizam que qualquer pessoa (mentalmente perturbada ou não), estando diante de um entrevistador experiente e não desejando se comunicar, por razões diversas, mas não podendo abandonar o campo, provavelmente inicia um tagarelar desconexo. Esse tagarelar não seria, pois, apanágio do insano, fazendo sim parte da comunicação de qualquer pessoa, em dadas circunstâncias.

Para esses pesquisadores a comunicação humana transmite informação (relato) e determina um comportamento (ordem). O relato é o conteúdo da mensagem transmitida, ou seja, a descrição que se faz dos fatos, a notícia que se dá. A ordem diz respeito ao aspecto relacional da comunicação, especificando o tipo de mensagem transmitida e a forma como deve ser considerada.

Os pesquisadores conjeturam que todas as interações comunicacionais são de dois tipos: simétricas (caracterizadas pela igualdade e minimização da diferença) ou complementares (baseadas na maximização da diferença). No primeiro caso, os parceiros tendem a refletir o comportamento um do outro. No segundo, o comportamento de um completa o do outro.

\section{Conceito de hospital}

A palavra vem do latim hospitale, estabelecimento onde se tratam e internam doentes. O sistema de assistência hospitalar, como modernamente se concebe, era desconhecido na antigüidade. Surgiu na Europa com o advento do Cristianismo. Os primeiros estabelecimentos desse gênero foram as basílias, da fundação de S. Basílio, bispo de Cesaréia. Durante as cruzadas surgiram os hospitalários, ordens diversas de cavaleiros destinados especialmente ao tratamento dos enfermos em hospitais primitivos. Na Idade Média algumas cidades fundaram hospitais (épocas de grandes epidemias de peste e cólera). Foi só no séc. XVII que o serviço hospitalar começou a se desenvolver, quando surgiram a Charité de Paris (1602), a Charitas, de Berlim (1710), o hospital de Lariboisière, também de Paris (1858), três estabelecimentos que, 
entre outros mais, fazem jus ao título de verdadeiros precursores dos modernos estabelecimentos hospitalares. ${ }^{22}$

\section{O hospital como organização}

É interessante verificar como funciona essa intituição. Segundo Teixeira ${ }^{23}$,

"O administrador no hospital tem menos autoridade e poder que em outras organizações, porque o hospital não pode ser organizado com base em uma linha única de autoridade. A coexistência de linhas de autoridade legal, profissional e mista gera um sem número de problemas administrativos. Ele tem quatro centros de poder, a diretoria superior, os médicos, a administração e os demais profissionais, entre os quais destaca-se a enfermagem".

A organização formal do hospital mostra que a direção superior tem toda a autoridade e a responsabilidade pela instituição. A diretoria delega ao administrador a gerência do dia-a-dia da instituição, o qual delega às chefias dos serviços sua autoridade de comando. O corpo clínico do hospital pode estar subordinado ao diretor e/ou administrador e o médico tem grande autonomia no seu trabalho e também autoridade profissional sobre outros na organização. Tal processo varia entre os tipos de hospitais.

O hospital tem pouco controle sobre seus públicos, principalmente os médicos e os pacientes. O trabalho hospitalar é diversificado e com pouca padronização. São pessoas cuidando de pessoas, participando ativamente do processo produtivo. Os serviços de atenção e tratamento são personalizados a cada paciente. Nas situações de emergência, a instituição tem definidas as responsabilidades dos diferentes membros da equipe e existe pouca tolerância aos erros. O valor econômico do produto organizacional é secundário ao valor social humanitário. É uma organização

\footnotetext{
${ }^{22}$ MAGAlHÃES, Álvaro (org.). Dicionário Enciclopédico Brasileiro Ilustrado. Rio de Janeiro, Porto Alegre, São Paulo, Ed. Globo, 1951, p. 874-5.

${ }^{23}$ TEIXEIRA, José Manuel de C. O hospital e a visão administrativa contemporânea. Calude Machline. et. al.; coord. Ernesto Lima Gonçalves, São Paulo Pioneira, 1983, p. 25.
} 
especializada, departamentalizada e profissionalizada, que não pode funcionar efetivamente sem uma coordenação interna, motivação, autodisciplina e ajustes informais e voluntários de seus membros. A coordenação de esforços e atividades é importante pela interdependência do trabalho que deve ser realizado.

Neste cenário complexo, acredita-se que a comunicação tem uma importante função a desempenhar, seja na articulação para o funcionamento adequado da organização hospitalar; seja na mediação entre o hospital e seus usuários, avaliando e recolocando questões pertinentes ao estabelecimento de um maior entendimento mútuo, principalmente em relação ao conflito "atendimento esperado/atendimento prestado". Objetivando conhecer melhor essa relação de conflito faz-se necessário uma conceituação dos seus principais agentes: a doença, o médico e o paciente.

\section{Conceito clássico e contemporâneo de médico}

O vocábulo designa aquele que pode exercer a medicina. Em um sentido figurado é aquilo que pode restabelecer a saúde (física ou moral). A história narra dois outros tipos que se incluem nesta classificação: o médico espiritual, confessor ou orientador moral, e o médico feiticeiro, o indivíduo que, nas tribos indígenas, se especializou na arte de curar doentes, aplicando-lhes práticas mágicas, às vezes, acrescidas de medicações empíricas e rudimentares. ${ }^{24}$

Para se ter uma visão mais ampla precisamos recuar no tempo histórico até o século XVII, com René Descartes, filósofo e matemático que foi o inspirador da ciência moderna. (Pessini, Barchifontaine, 1994)

Esses autores relatam a mudança na história da medicina ocidental sobrevinda com a revolução cartesiana. $O$ mundo começou a ser pensado de modo analítico, que consiste em decompor pensamentos e problemas em suas partes componentes e em dispô-los em sua ordem lógica. Isto constitui a base do moderno pensamento científico e possibilitou a concretização de importantes projetos tecnológicos.

Pessini e Barchifontaine destacam que:

\footnotetext{
${ }^{24}$ Novo Dicionário Aurélio da Língua Portuguesa. Editora Nova Fronteira, 1986.
} 
"Para Descartes, o universo era máquina e a natureza funcionava segundo rígidas leis mecânicas. Este tipo de raciocínio foi extrapolado para a medicina. O corpo humano é uma máquina que pode ser analisada nas suas diferentes peças e a doença é o mau funcionamento dos mecanismos biológicos. Ao negligenciar os aspectos sociais e ambientais, perdeu-se de vista a perspectiva integral. Este tipo de enfoque acaba deslocando a atenção do médico, do doente para a doença; a úlcera é mais importante do que o ulceroso. Os pacientes são vistos como conglomerados de enzimas, anticorpos e hormônios que não funcionam bem. Concentrando-se em partes cada vez menores do corpo, a medicina perde de vista o paciente como ser humano. Na verdade esta abordagem é reducionista e vê a saúde como um mero funcionamento mecânico do organismo.

Com os progressos da biologia e avanços da tecnologia médica, no século XIX, a atenção do médico começa a se deslocar para o estudo das doenças. Novas patologias são descritas e as doenças começam a ser rotuladas de acordo com um determinado sistema de classificação. Nesta época, as Santas Casas de Misericórdia se transformaram em centros de diagnóstico, terapia e ensino, até chegarem aos modernos hospitais. Assim, os avanços científicotecnológicos, ao lado do modelo cartesiano do ser humano, foram os responsáveis pela pulverização da medicina em especialidades e de uma prática cada vez mais médico-hospitalar."

Segundo Pessini e Barchifontaine pode-se classificar os médicos em três categorias: o médico-humano, o médico-sábio e o médico-tecnotrônico.

O médico-humano é aquele que ouve e examina atentamente o doente. É o amigo e o conselheiro. Acontece assim uma relação médico-paciente num nível profundo. Isto provoca uma descontração no doente com o restabelecimento do equilíbrio psicológico. Infelizmente, este tipo de profissional, o médico de família, está em extinção. Cabe a este médico o atendimento e o tratamento do paciente e, desde que necessária, a orientação para procurar um especialista. $O$ especialista, por sua 
vez, também deve estabelecer uma boa relação médico-paciente e não vê-lo como um repositório de sinais e sintomas.

O médico-humano vem cedendo lugar ao médico-sábio. Este é uma espécie de central de dados na qual o paciente chega e parte em seguida com uma receita. Este tipo de médico, quanto mais competente tanto mais é inacessível e silencioso. 0 paciente diante deste profissional hesita em lhe confiar suas angústias e temores e fala muito de seus padecimentos físicos.

Atualmente está-se entrando na era do "médico-tecnotrônico". Ele é um manipulador de técnicas requintadas de circuitos eletrônicos. No exercício da medicina, interpõe entre ele e o paciente um complexo de aparelhos; realidade esta que deu um golpe mortal na relação médico-paciente.

O médico-humano exerce uma medicina mais de doentes do que de doenças.

O médico-sábio exerce uma medicina cada vez mais de doenças e sempre menos de doentes. Para o médico-tecnotrônico, o futuro do doente já não se encontra mais em suas mãos, e sim na tecnologia.

\section{O ensino médico no Brasil}

O atual currículo médico dedica pouca ou nenhuma importância à formação humanista do médico. Os médicos dominam o instrumental, o saber técnico, o fazer, mas não estão preparados para uma relação mais fraterna com os pacientes, com a sociedade. O médico também não pode estabelecer uma relação caritativa com o paciente, porque poderia descaracterizar o ato médico. Mas, ao mesmo tempo, há um fosso de comunicação e conhecimento sobre o que se faz e por que se faz. ${ }^{25}$

A formação do médico no Brasil, infelizmente, reflete o país, em sua complexa e muitas vezes cruel heterogeneidade: São 85 as escolas médicas brasileiras credenciadas (dados do Conselho Federal de Medicina). A Medicina é a mais longa das formações profissionais: seis anos de graduação, dois a três de especialização,

\footnotetext{
${ }^{25}$ Revista Médicos. Entrevista com Professor Doutor Marcello Marcondes Machado. São Paulo, Hospital das Clínicas, março/98, p. 4-9.
} 
geralmente em programa de residência médica, seguidos de educação continuada, sem a qual é rápida a desatualização.

O curso de graduação forma o médico. A formação do especialista é melhor alcançada em programa específico de residência médica, e o docente-pesquisador é preparado em Programa de Pós-Graduação stricto sensu. Na graduação forma-se o médico e na residência, o especialista. Quando se pensa em currículo de curso de graduação em medicina, é importante conceituar especialidade médica e diferenciá-la de atividade médica.

O especialista não deve e nem pode ser formado durante o curso de graduação. O objetivo deste é transmitir ao aluno, das especialidades, o que deve fazer parte do conhecimento de todo médico, para que ele seja capaz de reconhecer os limites de sua atuação como não-especialista. Especialidade é o conjunto de conhecimentos de ciências básicas e clínicas que capacitam o médico ao diagnóstico e ao tratamento de doenças de determinado órgão ou aparelho; exige habilidades específicas para a execução de procedimentos diagnósticos e terapêuticos.

Atividade médica é ato que, por exigir habilidade e responsabilidade específicas, só pode ser exercido por médicos, mas que não envolve toda a gama de ações que caracterizam uma especialidade. Existem procedimentos diagnósticos e terapêuticos que sendo atividade exclusivamente médica e mesmo exigindo alto grau de aperfeiçoamento, não são uma especialidade médica, pois se limita a uma parte dessa (sub-especialidade).

Com freqüência um médico, individualmente, não domina todas as habilidades praticadas (sub-especialidades) no exercício de determinada especialidade. O aluno de graduação deve adquirir as habilidades básicas para o exercício profissional (começando pelo pleno domínio da anamnese e do exame clínico) que constituirão, juntamente com o conhecimento do método científico e dos preceitos éticos, a base de sua atuação como médico.

Ótima escola médica é aquela que abriga, em ambiente de produtiva e atualizada investigação científica, ótimos professores e alunos motivados. Isso significa que a excelência acadêmica não se limita à excelência em pesquisa, mas inclui a de ensino. Ao curso de Medicina, nas boas faculdades, têm acesso alunos que obtêm as 
maiores médias do vestibular. Essas instituições de ensino superior trabalham, portanto, com a elite estudantil do país.

Na maioria das escolas médicas, o curso tem seis anos de duração divididos em três ciclos: básico, clínico e internato. O curso de graduação, para a grande maioria dos formandos, complementa-se com o programa de residência médica (pós-graduação lato sensu) no qual buscam ao lado da especialização complementos para a formação teórica e prática que deveriam ter adquirido na graduação.

Não existe exigência legal de avaliação global/final do formando em medicina para que possa exercer a profissão; os conselhos regionais de medicina punem erros que porventura ocorram. É ação a posteriori.

\section{O médico brasileiro e o seu contexto de ação}

O médico, como outros profissionais, tem procurado se adaptar às mudanças que as novas tecnologias e também a globalização trouxeram para o seu dia-a-dia. Ele viu seu ofício ser invadido por máquinas e equipamentos dotados de alta complexidade, mas, principalmente, envolvendo altos custos de aquisição, manutenção e operacionalização. O exercício da medicina passou a ter uma dependência direta dessa tecnologia e também do capital que ela exige.

A vida humana, sua preservação, sua integridade e sua defesa, passaram a depender, cada vez mais, de capital e de investimentos. A saúde, ou melhor, a recuperação desta, passou a ser vista por alguns profissionais como cifras, margens de lucro e outros índices econômico-financeiros. Assim sendo, nas últimas décadas o Brasil passou a conviver com esses dois fenômenos mundiais interagindo na relação médico-paciente.

No que tange à tecnologia, os custos da atenção à saúde se elevaram a tais níveis que passaram a discriminar o ser humano: os que têm recursos para se beneficiar da mesma e os que não têm. Verifica-se também uma maior complexidade na relação dos médicos com as organizações públicas ou privadas, em decorrências desses mesmos fatores. 
Se existe desagrado dos pacientes quanto a essa situação, os médicos também mostram-se insatisfeitos e estressados; $80 \%$ dos médicos brasileiros, como mostra estudo realizado pela Fundação Oswaldo $\mathrm{Cruz}^{26}$, consideram a atividade médica desgastante, sendo os principais fatores de desgaste: excesso de trabalho/multiemprego, baixa remuneração, más condições de trabalho, responsabilidade profissional, área de atuação/especialidade, relação médico-paciente, conflito/cobrança da população, e perda da autonomia.

As associações de classe têm se preocupado com as questões referentes às condições de trabalho do médico. Assim, por exemplo, o Sindicato dos Médicos de São Paulo, em 1997, lançou uma campanha para o resgate da imagem social do médico: ${ }^{27}$

"Os constantes problemas que os cidadãos desse país têm enfrentado toda vez que precisam de algum atendimento na área de saúde, colocam o profissional médico na berlinda. Se falta remédio nos hospitais, a culpa é do médico. O médico também acaba sendo culpado pelas péssimas condições de atendimento, pela falta de estrutura. Na linha de frente na batalha pela saúde da população, o médico é quem mais sofre com desmazelo relegado ao setor. (...) Quem tem que arcar com as conseqüências imediatas de toda essa falta de estrutura é o médico. É em função disso tudo que a nossa campanha salarial, em 1997, vai além das questões econômicas e das garantias sociais, para trabalhar também o resgate junto à população da imagem do profissional".

As ações das associações de classe no sentido de recuperar o salário, as condições de trabalho e a imagem profissional diante da população são importantes para a melhoria desse quadro atual. Pois as repercussões psicológicas desses fatores acabam resultando em uma situação insatisfatória tanto para os médicos como para os pacientes.

\footnotetext{
${ }^{26}$ MACHADO, M.H. Os médicos no Brasil: um retrato da realidade. Rio de Janeiro, FIOCRUZ, 1997, p. 244.

${ }^{27}$ NOGUEIRA-MARTINS, Luiz Antonio; NOGUEIRA-MARTINS, Maria Cezira Fantini. $O$ exercício atual da Medicina e a relação médico-paciente. In: Revista Brasileira Clínica \& Terapêutica. São Paulo, Sociedade Brasileira de Clínica Médica, março/98, p. 60.
} 
O estudo da Fundação Oswaldo $\mathrm{Cruz}^{28}$ mostrou ainda que o desprestígio e perda do status acabam por afetar a forma como os médicos vão se relacionar não só com a sociedade em geral mas também com o paciente. $O$ sentimento de desvalorização profissional é facilmente percebido na maioria dos médicos, levando a uma perda da auto-estima.

Esse contexto vai, gradativamente, criando um terreno propício à animosidade entre médico e paciente, que provavelmente vai gerar uma predisposição negativa mútua. As conseqüências para a relação do médico com seus pacientes podem ser: ${ }^{29}$ humor depressivo, irritabilidade, ansiedade, rigidez, negativismo, ceticismo e desinteresse são sintomas psicológicos típicos de uma vida profissional tensa e atribulada. Fazer consultas rápidas, colocar rótulos depreciativos, evitar os pacientes e o contato visual são alguns exemplos de comportamentos de um profissional que está desgastado. Nessas situações, o paciente sente o médico desinteressado e tende a não colaborar;

Ou ainda a construção de uma couraça impermeável às emoções e sentimentos, que se expressa por um embotamento emocional traduzido por uma aparente "frieza" no contato com o paciente é também um sinal de desgaste médico.

Como existe uma grande expectativa social de que o médico coloque as necessidades dos pacientes em primeiro lugar o profissional, evitando o contato com as próprias angústias e frustrações, poderá refugiar-se nas atividades profissionais, sentindo-se necessário e insubstituível. Esta posição não é benéfica nem para o médico nem para o paciente.

A ironia e o humor negro que os médicos desenvolvem é outra expressão de uma inadequada adaptação dos rigores e às crescentes dificuldades da profissão. $O$ desenvolvimento crescente do humor negro através da linguagem irônica e amarga e do uso de um jargão em que predominam rótulos depreciativos revela uma incapacidade de lidar com as frustrações e tristezas da tarefa profissional.

Uma forma de evitar o paciente é o pedido exagerado de exames e encaminhamento a vários especialistas, "diluindo" assim a relação, transformando-a

\footnotetext{
${ }^{28}$ MACHADO, M.H, op. cit.

${ }^{29}$ NOGUEIRA-MARTINS, Luiz Antonio; NOGUEIRA-MARTINS, Maria Cezira Fantini, op. cit., p. 61 .
} 
numa relação anônima. O paciente pode, então, se sentir desamparado e sem referências.

Habitualmente os pacientes tendem a perceber seus médicos como possuidores de um grande saber e de uma autoridade poderosa. Isto os deixa mais seguros, mas também, mais dependentes do médico. Se a auto-estima do médico estiver abalada, ele poderá extrair uma gratificação patológica da dependência do paciente e da idealização que freqüentemente a acompanha. Isto pode resultar em um comportamento, por parte do médico, de reforçar no paciente aspectos infantis que se acham além do que é terapeuticamente benéfico.

\section{Conceito clássico e contemporâneo de paciente e de doença}

Do latim patiente, define aquele que espera serenamente um resultado; que persevera na continuação de uma tarefa lenta e difícil; pessoa que padece, doente; pessoa que está sob cuidados médicos sofredor, o paciente.

$\mathrm{Na}$ filosofia, paciente é aquele que sofre ou é objeto de uma ação. Gramaticalmente, é aquele que recebe a ação praticada por um agente.

Doente do latim dolente é aquele que tem doença, está enfermo, fraco, achacadiço, por extensão é aquele que sofre mal moral. Doença, do latim dolentia, significa falta ou perturbação da saúde, moléstia, mal, enfermidade. ${ }^{30}$

Doença é a situação oposta à saúde. Representa um estado transitório ou definitivo, reversível ou irreversível, de equilíbrio ou desarmonia, limitada ou ampla, simples ou complexa, entre as estruturas, funções e faculdades existentes no homem integral. Daí doenças somáticas e psíquicas, conforme domine no quadro a componente corpórea ou a anímica. Sua manifestação faz-se através de sintomas: subjetivos quando percebidos só pelo próprio doente; objetivos, quando reconhecíveis por um observador adestrado, o médico, e, algumas vezes, até por indivíduos inexperientes. Quanto aos agentes morbígenos, agrupam-se em quatro categorias:

\footnotetext{
${ }^{30}$ Novo Dicionário Aurélio da Língua Portuguesa, op. cit.
} 
mecânicos, físicos, animados (parasitários e infeciosos) e psíquicos. ${ }^{31}$, não descritos aqui por não serem relevantes aos objetivos deste trabalho.

\section{A doença}

Cesar Paulo Alves e Miriam Cristina Rabelo ${ }^{32}$ mostram que, para a antropologia, a enfermidade se constitui em uma experiência de caráter sociocultural que reflete um complexo interativo entre indivíduo, grupos e instituições. Que a enfermidade é, antes de mais nada, uma sensação de mal-estar, uma expressão direta do sofrimento. Parte então de um pressuposto anterior de bem-estar corporal e psíquico. Uma das tarefas da antropologia da saúde é compreender como a enfermidade, radicada em uma experiência individual, subjetiva, do corpo, se constitui em realidade social.

\section{A consulta: fases e prontuário}

Fazem parte da consulta os agentes médico e paciente. Em geral ela ocorre em um ambiente fechado. Já que existe a questão do sigilo (Artigo11 do Código de Ética Médica, anexo 1).

A rigor são quatro as suas etapas, depois que o paciente entra no consultório/ambulatório: a anamnese (relato dos padecimentos feito pelo doente ao médico), o exame clínico (observação visual e tátil do paciente); o diagnóstico (conhecimento ou determinação duma doença pelos sintomas e/ou mediante exames diversos - radiológicos, laboratoriais etc.) e o prognóstico (juízo médico, baseado no diagnóstico e nas possibilidades terapêuticas, acerca de duração, evolução e termo de uma doença) ${ }^{33}$.

$\mathrm{Na}$ anamnese o médico cria o ambiente para o histórico, por parte do paciente, das suas dores e preocupações. É através deste depoimento que o médico vai coletando dados e informações indispensáveis ao diagnóstico. É o médico quem conduz o diálogo, embora mais ouça que fale. A anamnese é uma fase importante,

\footnotetext{
${ }^{31}$ MAGALHÃES, Álvaro (org.), op. cit., p. 573.

${ }^{32}$ ALVES, Cesar Paulo; RABELO, Miriam Cristina. Significação e metáforas, aspectos situacionais no discurso da enfermidade. In: Saúde e comunicação, visibilidades e silêncios. São Paulo, Husitec, 1995, p. 215.

${ }^{33}$ Novo Dicionário Aurélio da Língua Portuguesa, op. cit.
} 
pois, quando feita de maneira incompleta, por demais rápida e, consequentemente, com dados e informações insuficientes, pode confundir e retardar o diagnóstico, frustrando o paciente, prolongando o período de seu sofrimento.

O exame clínico, que se segue à anamnese, dará ao médico a confirmação ou não de um suposto diagnóstico. Nele o médico pesquisa, através dos seus sentidos, sinais e respostas confirmatórias de suas suspeitas. O exame clínico é um recurso que complementa a anamnese. Ele deve ser pormenorizado. Nesse momento se processa uma comunicação ágil, feita de perguntas e repostas sucintas. O exame clínico é uma espécie de caixa de Pandora, pois fornece ao médico dados não verbalizados pelo paciente anteriormente. Ao procurar cuidadosamente os sinais e sintomas, o médico observa, apalpa, ausculta e percute. Começa aqui uma minuciosa elaboração do raciocínio clínico: transformar os dados e informações da anamnese e as descobertas provenientes do exame clínico em possibilidade de diagnóstico. Não raro, para confirmar o diagnóstico, o médico solicita exames laboratoriais. A avaliação de quais exames são indispensáveis é da competência do médico.

Em uma terceira etapa o médico, se dispuser de certeza suficiente, faz o diagnóstico e o comunica ao paciente. Nesse momento ele esclarece, argumenta, justifica, explana e orienta. Se o médico, em uma primeira consulta, não tiver certeza suficiente para fazer o diagnóstico, deve colocar o paciente a par de suas dúvidas. Não há obrigação de um diagnóstico imediato e nem são as dúvidas sinais de incompetência. São, muitas vezes, demonstração de seriedade profissional, humildade e franqueza.

Em uma quarta etapa, se o médico já diagnosticou a doença, é feito o prognóstico onde ele explica ao paciente os procedimentos que precisa ter a respeito dos remédios, alimentação, exercícios, vícios etc., reforçando a importância da colaboração do paciente para o sucesso do tratamento.

As fases da consulta não devem ser um processo mecânico. Ao receber o paciente é importante que o médico ${ }^{34}$ :

\footnotetext{
${ }^{34}$ ROLIM, Ernani. A importância do clínico no Século XXI. Palestra de abertura do Congresso Brasileiro de Clínica Médica. São Paulo, 1997.
} 
"Estabeleça com ele uma relação humana positiva, postandose perante o doente como alguém que quer melhor compreendê-lo para melhor ajudá-lo, numa atitude de receptividade e irmandade; estreitando ainda mais este relacionamento ao examinar detalhada e atentamente o paciente, ao sentir o seu hálito, a sua atitude, sua vivacidade ou tristeza e o seu sofrimento pela doença; ao palpá-lo através das clássicas manobras propedêuticas, como que acariciando alguém que sofre, e ao se utilizar do estetoscópio, símbolo médico relevante do clínico, completa a interação do médico-paciente. Examina-o sempre por inteiro, como um todo, absorvendo o que disso pode captar."

A Lei 10.241 (anexo no. 2) detalha quais são os direitos dos usuários dos serviços de saúde no Estado de São Paulo.

Ao receber o paciente para a consulta o médico deve fazer uma ficha de atendimento, o prontuário. (Artigo 69 do Código de Ética Médica). Segundo a Resolução CFM 1.331/8935, o prontuário consiste em um conjunto de documentos padronizados e ordenados, provenientes de várias fontes, destinados ao registro dos cuidados profissionais prestados ao paciente. Possui propósito pessoal e interpessoal. Serve para o paciente, a instituição, os profissionais de saúde e para a sociedade como um todo.

É utilizado para planejamento, análise e avaliação dos cuidados do paciente e como meio de comunicação entre profissionais de saúde que assistem o paciente.

O prontuário contém, entre outros documentos, as fichas de atendimento ambulatorial ou hospitalar, com dados de anamnese, história de vida, motivo de internação, exame físico, psicológico, evolução, prescrição terapêutica, procedimentos cirúrgicos e anestésicos, ondontológicos, fichas de acidentes de trabalho, exames complementares laboratoriais e radiológicos, papeletas de cuidados de enfermagem e de outros profissionais. Também compõe o prontuário documento de cunho administrativo, como relatórios de ocorrências e de alta e resultados de autópsia.

\footnotetext{
${ }^{35}$ FORTES, Paulo Antonio de Carvalho. Ética e saúde. São Paulo, EPU, 1998, p. 66.
} 
O prontuário é legalmente propriedade física dos estabelecimentos de saúde, mas tem informações que estão no campo do direito moral e legal dos pacientes. $O$ direito do paciente requer que as informações a ele concernentes sejam adequadamente registradas no prontuário. A importância da guarda e manutenção do mesmo é evidenciada quando da falta de informações, que pode resultar em danos para o paciente durante o acompanhamento no serviço ou mesmo posteriormente.

Faz-se necessário lembrar que o acesso de cada cidadão às informações que Ihe digam respeito e constem de registros ou bancos de dados de entidades governamentais ou de caráter públicos, é um direito do cidadão brasileiro, inserido na Constituição. Todos serviços de saúde, os estatais ou os de natureza privada lucrativa, têm relevância pública e devem obedecer a esse princípio legal. Cabe ao paciente, caso the seja negado o acesso às suas informações, utilizar-se do "habeas data, recorrendo, através do Poder Judiciário local, não somente para ter acesso à informação, mas também para retificá-la quando seja o caso. (C.F., art. 5o, LXXII).

\section{Fundamentos psicológicos da relação médico-paciente}

A proposta desse estudo visa o processo comunicativo entre o médico e 0 paciente, é necessário então uma incursão na área da psicologia para buscar os elementos indispensáveis ao processo interativo, que resulta dessa comunicação. As maiores contribuições para o entendimento da relação médico-paciente vieram do campo da Psicologia Médica, disciplina que se propõe a estudar a psicologia do estudante, do médico, do paciente, da relação entre estes, da família e do contexto institucional destas relações ${ }^{36}$. Resultado da união dos conhecimentos vindos da escola psicanalítica com as contribuições de outras disciplinas das áreas humanas Sociologia, Antropologia e Psicologia Social - a Psicologia Médica cresceu sob a influência dos trabalhos de Balint ${ }^{37}$, a respeito do campo dinâmico da relação médicopaciente e tem se fortalecido com os estudos sobre as instituições médicas.

\footnotetext{
${ }^{36}$ NOGUEIRA-MARTINS, Luiz Antonio; NOGUEIRA-MARTINS, Maria Cezira Fantini, op. cit., p. 62.

${ }^{37}$ BALINT, Michael. O médico, seu paciente e a doença. Rio de Janeiro, São Paulo, Atheneu, 1988, p. 331.
} 
Com a obra de Balint e seus seguidores, foi ressaltada a importância psicológica da inter-relação entre o médico e o paciente, a partir dos conceitos de transferência e de contratransferência.

Dá-se o nome de transferência ao processo pelo qual são trazidos para o relacionamento atual sentimentos e conflitos originários de relacionamentos importantes no início da vida; nesse fenômeno psicológico, há um transporte de reações emocionais do passado para o presente. Esse fenômeno pode resultar em ligações afetivas intensas, irracionais, que não podem ser explicadas em situações na vida atual ${ }^{38}$.

$\mathrm{Na}$ maioria dos pacientes a transferência é predominantemente positiva e contém tipos de expectativas e sentimentos que um dia foram dirigidos para bons pais, que eram sentidos e percebidos como a principal fonte de força e segurança. Os pacientes têm uma tendência a investirem o médico com propriedades poderosas e onipotentes, semelhantes às que as crianças acham que seus pais possuem, quando ainda responsáveis por elas. O paciente se sente pequeno, desamparado, à mercê do médico; a crença no poder do médico permite-lhe sentir-se seguro na situação de perigo. Dentro dos limites razoáveis, a transferência positiva constitui um dos elementos do relacionamento médico-paciente que tem efeito benéfico no tratamento.

A transferência do paciente para com o médico também pode ser negativa. Neste caso, a atitude do paciente se tinge de algum matiz da escala negativa de sentimentos, tais como a desconfiança, a inveja, o desprezo, a irritação ou até mesmo a raiva. Pode-se apresentar sob a forma de reserva geral, escassez de informações ou pouca disposição de cooperar durante o exame e o tratamento. Ela também se pode expressar através de sintomas que se tornam acentuados e mais sérios após o paciente haver começado o tratamento ou mediante complicações inesperadas e atraso na recuperação.

A contra-transferência designa os movimentos afetivos do médico como reação ao de seu paciente e em relação à sua própria vivência infantil. A contra-transferência pode também ser positiva ou negativa e depende de inúmeros fatores, advindos tanto

\footnotetext{
${ }^{38}$ MARMOR, J. O médico como psicoterapeuta. In: USDIN G.; LEWIS, J.M. Psiquiatria na prática médica. Rio de Janeiro, Guanabara Koogan, 1981, p. 404-415.
} 
do paciente (idade, sexo, situação social, apresentação e comportamento) como do próprio médico (estado de cansaço, irritação, situação conjugal, social e de trabalho) ${ }^{39}$.

A contra-transferência, quando negativa, pode-se manifestar por atitudes que ocultam rejeição ou agressividade inconsciente, como por exemplo: recusa de ouvir o paciente, por motivo de pressa ou falta de tempo, atos falhos, como esquecimento do horário de atendimento, ameaça de consulta psiquiátrica ou de hospitalização ${ }^{40}$.

É nas consultas que se fará sentir toda a força dos dinamismos instintivo-afetivo, que definem os campos de transferência e da contra-transferência.

\section{A interação médico-paciente}

Quando o paciente procura o médico, traz com ele duas doenças parciais: a disfunção original e a reação de sua personalidade a ela. Não há disfunção sem a concomitante reação psíquica e somática. $\mathrm{A}$ intensidade desta reação à doença varia conforme o histórico de vida do paciente. Do mesmo modo, a maneira pela qual ele vai entrar em contato com o médico depende do tipo das suas relações primárias e secundárias e do seu nível cultural.

Assim, há o paciente que espera do médico poderes mágicos e aquele que anseia por um profissional tecnicamente capacitado para livrá-lo da doença. Não raro, o primeiro sai frustrado do relacionamento limitado que se estabelece, pois constata que o médico não é um ser divino. Já o segundo, tem possibilidades de encontrar identificação e colaborar eficazmente com o médico, facilitando de forma ampla a tarefa deste. Em geral, o que o paciente deseja do médico fica implícito no primeiro contato entre eles. Uns querem milagres, atenção, carinho e apoio. Outros buscam soluções técnicas, vindas de alguém que conquistou sua confiança e de quem esperam competência, sensibilidade, compreensão e solidariedade.

\footnotetext{
${ }^{39}$ JEAMMET, P.; REYNAUD M.; CONSOLI S. Manual de Psicologia Médica. São Paulo, Durban, 1989, p. 421.

${ }^{40}$ JEAMMET, P.; REYNAUD M.; CONSOLI S., op. cit.
} 


\section{A saúde pública no Brasil}

O serviço de saúde pública brasileiro tem passado, nos últimos anos, por uma séria crise financeira e institucional. Se por um lado, o Estado não dispõe de verbas suficientes para financiar o sistema, por outro lado o número de usuários tem aumentado a cada ano, em virtude da impossibilidade de poder pagar um serviço de saúde privado. Este descompasso resulta na queda da qualidade dos serviços prestados pelas instituições públicas, incluindo o atendimento hospitalar, e uma crescente insatisfação por parte dos profissionais, que atuam na saúde, e da comunidade que recebe $o$ atendimento.

Constantemente, a mídia nacional divulga episódios envolvendo incidentes nesta área, como as péssimas condições de atendimento, a falta de estrutura e de equipamentos e também a carência de médicos nos postos e hospitais da rede pública.

Em contrapartida, da área da pesquisa científica chegam informes dos avanços mundiais da ciência e da medicina no combate às doenças, seja pelos avanços tecnológicos, que permitem um tratamento mais eficaz, ou pela descoberta de novos remédios. Estas buscas de cura são cada vez mais sofisticadas e, conseqüentemente, mais dispendiosas, aumentando a distância entre os que têm possibilidade de acesso a um sistema de saúde moderno e os que não têm.

Essas duas realidades distintas provocam uma tensão entre o que o paciente e o médico podem esperar de um atendimento médico e hospitalar, e o que realmente está disponível para a população, através do sistema público de saúde brasileiro. $\mathrm{O}$ conflito gerado por esta dualidade, consequentemente, é levado para dentro do hospital no momento do atendimento. A superação desta situação conflituosa é um dos maiores desafios para que a área da saúde pública restaure parte de sua credibilidade junto à população e preste o melhor serviço possível aos seus usuários, mesmo considerando todas as suas carências estruturais.

A comunicação que se processa no interior da organização hospitalar, desempenha um papel fundamental, a partir do momento em que ela é a responsável 
pela distribuição dos fluxos de informação e pelo conteúdo das mensagens divulgadas. Para Mattelart ${ }^{41}$ :

"A empresa concebida como sistema interativo extremamente complexo - que deve enfrentar o irracional no interior e o imprevisível no exterior - a circulação de fluxos de comunicação não deve ser interrompida. A informação é a vida (grifo nosso), o fluxo vital, para manter o tom. Daí o conflito permanente entre a necessidade de transparência e a manutenção de uma certa imagem. Daí, igualmente, a dificuldade de passar além de uma transparência entendida como uma coisa diferente dessa luta pela legitimidade e credibilidade da empresa por via da comunicação".

O autor parece fazer uma analogia da importância vital da comunicação para as organizações como o sangue é para os animais.

De acordo com a teoria de sistemas ${ }^{42}$ aplicado às organizações, a comunicação executa uma "função limite", atuando na margem da organização, servindo de elemento de ligação entre a organização e os públicos. Para Grunig ${ }^{43}$, "normalmente, as organizações desenvolvem um subsistema formal de comunicação quando a organização ou seus públicos agem de modo que um traz conseqüências sobre o outro" como é o caso dos hospitais.

Essas conseqüências recíprocas criam um problema de comunicação, pois a partir do momento em que os públicos passam a ser informados sobre esses efeitos, eles também realizam ações que tem resultados sobre a organização. É no limite desta tensão que a área de comunicação empresarial vai atuar.

\footnotetext{
${ }^{41}$ MATTELART, Armand. Comunicação-Mundo. Histórias das idéias e das estratégias. Petrópolis, Vozes, 1994, p. 261.

${ }^{42}$ MATTELART, Armand, op cit.

${ }^{43}$ GRUNIG, J.; HUNT, T. Managing public relations, New York, Holt, Rinehart \& Winston, 1994. p. 132
} 


\section{A visão dos governos federal e estadual a respeito da saúde}

Esse estudo é sobre a comunicação em um hospital público, situado em São Paulo, considerada o estado mais importante da Federação devido à sua participação de $35,61 \%$ no $\mathrm{PIB}^{44}$ de todo o país, é necessário contextualizar como os governos federal e estadual percebem a interferência da problemática da saúde na vida dos brasileiros e principalmente na população mais carente. Alguns trechos do discurso de posse de José Serra no Ministério da Saúde, no dia 31 de março de 1998, em Brasília, nos dão uma visão federal sobre essa área: ${ }^{45}$

"Minhas primeiras palavras são de agradecimento ao presidente da República, Fernando Henrique Cardoso, pela confiança de depositar em mim a responsabilidade pela condução deste ministério.

Desculpem-me a banalidade da metáfora: a saúde de um povo é um termômetro da sociedade.

A saúde de um povo, ou pelo menos o que um povo pensa sobre o estado geral de sua própria saúde, reflete de forma extremamente sensível os mais diversos aspectos da sociedade. Incidem sobre as condições de saúde fatores tão díspares quanto $o$ nível de emprego, as taxas de salários, a inflação, as formas de organização familiar, os acidentes de trânsito, os investimentos em saneamento, os hábitos de higiene familiar, fenômenos ambientais e, particularmente, um conjunto de ações que podemos denominar políticas de saúde, em cujo vértice encontra-se o Ministério da Saúde.

É sempre a esse vértice que é atribuída a responsabilidade principal pelas eventuais subidas do termômetro, mesmo quando tal elevação possa ter sido provocada por qualquer daqueles numerosos fatores, sós ou combinados.

Embora seja quanto à eventual distribuição de fatores causais, o termômetro não o é em relação à distribuição de culpas. Aponta

\footnotetext{
${ }^{44}$ Fonte: Almanaque Abril 1996.

${ }^{45}$ FOLHA DE S. PAULO. Discurso de posse de José Serra como ministro da Saúde, 1/4/98, p. 1-6.
} 
sempre para o governo, principalmente o federal e, particularmente, para o Ministério da Saúde.

Mas tal reflexão não tem, para mim ou para o presidente Fernando Henrique, nenhuma implicação negativa. Ao contrário. 0 Ministério da Saúde tem que fazer sua parte. Toda vez que ele encarnar efetivamente o vértice de responsabilidade pelos problemas que aparecem abrir-se-á uma chance nova para revigorar o seu trabalho e sua ação."

\section{(...)}

"É nesse contexto que situo, na linha de pensamento do presidente Fernando Henrique, princípios e idéias que nortearão a ação do Ministério da Saúde:

É correta a orientação constitucional que consagra a universidade do atendimento à saúde. Atendimento a toda a população e o atendimento deve ser integral, unindo a atenção preventiva e curativa. É preciso garantir que todas as pessoas que não disponham de informação e dinheiro tenham acesso a esse direito. Não podemos entrar no século 21 sem cumpri-lo de forma decente."

\section{(..)}

"Área social não é e não pode ser sinônimo de desperdício, precariedade administrativa, falta de metas e baixa qualidade dos serviços. Desde logo, vou me empenhar em esclarecer exatamente por que há hospitais públicos que funcionam tão bem e outros que funcionam que tão mal, sobre condições exógenas parecidas. Do mesmo modo, porque alguns municípios que já tiveram muita dengue conseguiram livrar-se dela completamente e outros, pelo contrário, pioraram. Investigaremos esse assunto, não em busca de culpados, mas em busca de conclusões que permitam estimular, incentivar a generalização do bom serviço. 
Neste aspecto, aliás, quero ressaltar a importância de aprimorar a rede de santas casas e hospitais universitários, com a implantação de programas de qualidade e o estímulo à montagem de planos de saúde. Temos de transformar a qualidade do atendimento à saúde numa verdadeira obsessão nacional. Convidaremos mesmo cada grande empresa brasileira que já tinha obtido excelência em qualidade para implantar e supervisionar métodos de qualidade total em um hospital público."

Um ano é passado e, ao que parece, a vontade política do Ministro José Serra não conseguiu trazer para o plano prático algumas das suas propostas como, por exemplo, garantir que todas as pessoas que não disponham de informação e dinheiro tenham acesso a saúde e também o de transformar a qualidade do atendimento à saúde numa verdadeira obsessão nacional. Tem-se hoje uma estrutura social injusta, que cria profundos desníveis e fere a sociedade de forma impiedosa e perversa. E é principalmente na área da saúde pública que se percebe esse desnível, onde um percentual significativo da população é obrigada, por razões diversas, mas principalmente a econômica, a buscar os serviços públicos e estes, apesar de uma contribuição financeira constante, através de impostos compulsórios, não fazem uma justa aplicabilidade dos seus recursos, oferecendo assim serviços deficientes e condições de trabalhos injustas aos seus servidores.

A mídia tem-nos colocado a par diariamente dos problemas que o usuário dos hospitais públicos, independente do estado em que se localiza, continua enfrentando assim como exemplos da precariedade administrativa, falta de metas e a baixa qualidade desses serviços.

A posição do governador Mário Covas sobre o assunto é dada em uma entrevista concedida por ele ao Jornal 19 Anos Bastam! da Associação Médica do Instituto de Assistência Médica ao Servidor Público Estadual ${ }^{46}$.

\footnotetext{
${ }^{46} 19$ ANOS BASTAM! Jornal da AMIAMSPE (Associação Médica do Instituto de Assistência Médica ao Servidor Público Estadual). São Paulo, junho/98, ano I, no 1, p. 2-3.
} 
Questionado como ele imagina o futuro da assistência médica pública no Estado de São Paulo, o governador respondeu:

"A minha visão sobre a assistência médica pública está consubstanciada no meu programa de Governo, que nestes mais de três anos tenho procurado transformar em realidade. $O$ ponto primordial desse programa é a prevenção. A nossa preocupação é tratar da saúde, e não da doença. Atrair para os programas preventivos os grupos sociais mais carentes. E criar condições para melhorar a qualidade de vida da população, desenvolvendo um amplo programa de saneamento.

Ao lado disso, temos buscado descentralizar o atendimento, colocando os serviços de saúde mais perto da população, apressando a implantação do Sistema Único de Saúde, o SUS. Ainda para tornar mais ágil e eficiente esse atendimento, estamos tratando de engajar nesse trabalho a sociedade civil, através de suas entidades ligadas à saúde. Por exemplo, numa iniciativa inédita e inovadora, para garantir o funcionamento dos nove hospitais cujas obras foram retomadas, entre os 14 que encontramos paralisados, estamos propondo à Assembléia Legislativa a entrega da gestão desses estabelecimentos a organizações sociais que tenham mais facilidades que o Estado para contratação de pessoal e outras medidas necessárias para viabilizar a sua entrega mais rápida à população."

O Governador tem-se mostrado sensível às situações adversas que o sistema de saúde público paulista vem enfrentando. Entretanto suas medidas de caráter econômico e social (higiene, saneamento básico, educação e habilitação) não trouxeram melhorias perceptíveis para os servidores e usuários do sistema de saúde pública.

Percebe-se que no plano político existe uma intenção de modelo de saúde pública que na prática não se desenvolve. Daí decorre a insatisfação dos médicos quanto a sua jornada de trabalho, honorários considerados aviltantes e condições 
insatisfatórias para o atendimento do grande número de pacientes que são agendados diariamente.

E, apesar de todo o progresso que sofreu a Medicina, no Brasil não existe uma política nacional ou estadual de se criar um programa de prevenção às doenças, o que certamente pouparia muitas vidas e reduziria investimentos maiores para se tratar a doença.

\section{O Hospital do Servidor Público Estadual "Francisco Morato de Oliveira"}

Com o propósito de complementar o estudo, foi realizada uma pesquisa de campo a fim de analisar a competência comunicativa em uma organização hospitalar pública. Para tanto, optou-se pela realização do estudo no Hospital do Servidor Público Estadual do Instituto de Assistência Médica ao Servidor Público Estadual - IAMSPE, ligado à Secretaria da Saúde do Governo do Estado de São Paulo.

O IAMSPE, inaugurado há 38 anos, com uma área útil atual de $108.000 \mathrm{~m}^{2}$, possui 699 leitos e realizou, em 1998, 1.108.754 consultas sendo que 141.650 foram no atendimento do Pronto Socorro. Por sua história no atendimento à saúde dos funcionários públicos no Estado de São Paulo, o IAMSPE tem se caracterizado como uma das instituições mais dinâmicas e preocupadas com as políticas públicas nacionais de saúde. Entre seu quadro de profissionais, encontram-se 784 médicos distribuídos em 43 especialidades. Por se tratar de uma instituição que incentiva 0 ensino, a pesquisa e o aperfeiçoamento no campo da medicina, o IAMSPE, conta também com 297 médicos residentes e 70 internos (cursando o 6ํano de Medicina).

O Hospital do Servidor Público Estadual "Francisco Morato de Oliveira" é uma organização social extremamente complexa, que difere de outras organizações hospitalares em algumas características importantes. O IAMSPE, órgão ao qual o Hospital pertence, é uma autarquia, subordinado à Secretaria da Saúde, e é mantido pelos próprios servidores públicos - ativos e inativos - do Estado, que contribuem compulsoriamente com $2 \%$ dos seus salários. O valor médio pago é de $R \$ 14,00$, não 
importando quantos dependentes o funcionário tenha. Apenas 36,2\% dos usuários são funcionários públicos, os $63,8 \%$ restante são dependentes ${ }^{47}$.

O Hospital do Servidor Público Estadual, cuja missão institucional é prestar assistência médica ao servidor público estadual, tem uma demanda de pacientes em potencial da ordem de 750 mil funcionários. Considerando que cada servidor possui em média três dependentes (ascendentes e descendentes) tem-se então mais de 2 milhões e 250 mil de possíveis usuários.

Os funcionários do IAMSPE, em número de 3.361 não são obrigados a contribuir, mas podem usufruir daqueles serviços. Aliado a isso, o Hospital é conveniado com o Serviço Único de Saúde - SUS, o que aumenta substancialmente a demanda pelos serviços.

${ }^{47}$ JORNAL DO IAMSPE. DECAM (Departamento de Convênios e Assistência Médica Ambulatorial) faz reunião de balanço, outubro/98, ano IX, n 55, p.3. 


\section{Capítulo III}

\section{O cientismo e o estudo}

\section{Referencial metodológico}

No sentido não só de melhor equacionar as afirmações conceituais efetuadas no campo teórico, mas também ampliar o material existente sobre a questão da comunicação hospitalar, utilizamos o estudo de caso, que permitiu o levantamento de dados sobre pacientes e médicos do Hospital "Francisco Morato de Oliveira" - os quais subsidiaram o estudo descritivo da pesquisa.

Demo $^{48}$, em Introdução à metodologia da ciência, versando sobre estudo de caso, diz que:

"A mesmo não pode ser entendido como a captação de meras particularidades e sim para depurar generalizações indevidas ou excessivamente abstratas. No fundo, não conseguimos captar cientificamente algo que é somente individual, porquanto teríamos que inventar uma nova ciência para cada indivíduo. Explicamos pela constância das diferenças, não pelas diferenças mesmas.

Neste sentido, temos a crença de que a dinâmica dos fenômenos não é algo caótico, que acontece dentro do inesperado, totalmente imprevisto; ao contrário, associamos à idéia de movimento ordenado.

Ao lado da abstração generalizante é importante ressaltar a crença na relação causa e efeito. Explicamos um efeito, se encontrarmos uma causa. Em medicina isto é um esquema fundamental. Só se consegue curar uma doença, se sabemos sua causa. Não podemos confundir sintomas com efeitos diretamente causais. Por exemplo, cefaléia pode ser causada por preocupação psicológica e também por distúrbios na cabeça”.

\footnotetext{
${ }^{48}$ DEMO, Pedro. Introdução à metodologia da ciência, São Paulo, Atlas, 1991, p 56.
} 
Considerou-se que o projeto de pesquisa devia ser concebido em função de um problema específico. O que determinou a escolha da metodologia a ser adotada foram as peculiaridades da situação. É importante também o grau de liberdade que o pesquisador teve na condução da pesquisa, não se esquecendo dos procedimentos do método como os recursos da técnica.

É bom lembrar que o tipo de dados que se coletou tem uma natural influência na classificação da pesquisa e no conjunto de procedimentos e técnicas que podem ser qualitativas ou quantitativas. Entre as técnicas mais utilizadas na pesquisa qualitativa está inserida a entrevista. Mesmo com um esquema preestabelecido, ela possibilita ao entrevistador vários questionamentos e observações que o levarão a um levantamento de opiniões e conclusões diversas.

Segundo Parasuraman ${ }^{49}$, "a pesquisa qualitativa corresponde à coleta, análise e interpretação daqueles dados que não podem ser quantificados, isto é, sumarizados sob a forma de números. A pesquisa quantitativa, por seu turno, é caracterizada por sua maior estruturação e maior amplitude e representatividade de amostra".

Para Minciotti 50 , "uma marca muito comum a quase todos os estudos qualitativos é a necessidade de desenvolver um entendimento inicial a respeito do assunto a ser pesquisado, enquanto que os problemas tratados pelas pesquisas quantitativas, normalmente, pedem por dados específicos, a serem utilizados na escolha de um determinado curso de ação." O autor diz ainda que "a pesquisa quantitativa, pela necessidade de ter dados inferidos para o universo, utiliza processos de amostragem probabilísticos, e técnicas estruturadas de coletas de dados como, por exemplo, o questionário ou a entrevista estruturada. É freqüentemente utilizada nos estudos onde se pretende identificar "quem", "quantos", "como" e "onde", porém ela não é adequada para responder aos "porquês".

Trujillo $^{51}$ exemplifica a utilização dos levantamentos na área do Serviço Social, onde "o estudo de campo pode ocorrer considerando o método do estudo de caso, as técnicas de amostragem, observações controladas, entrevistas, aplicação de formulários, questionários, testes e escalas, seguidos de análises".

\footnotetext{
${ }^{49}$ PARASURAMAN, apub Silvio Augusto Minciotti, op. cit., pg. 128-9.

${ }^{50}$ MINCIOTTI, Silvio Augusto, op. cit. pg. 129.

${ }^{51}$ TRUJILLO, apub Silvio Augusto Minciotti, op. cit. pg. 137.
} 
Downs $^{52}$ observa que os questionários são muito usados pelos pesquisadores por terem a vantagem sobre outros métodos de coleta de dados. Adverte, entretanto, que o desenho de um bom questionário não é fácil e que é importante pensar como se planeja usar as informações que se obterá com as respostas.

Neste estudo optou-se pelo questionário na pesquisa de campo, com questões abertas, semi-abertas e fechadas, por suas vantagens: a) economia: ser auto administrável, possível redução do número de pesquisadores e de ser um meio rápido para se obter as informações; b) padronização: instruções escritas reduzem viés na administração e interação com o entrevistador; c) sigilo: privacidade estimula respostas honestas às questões sensíveis; d) perenidade: é uma fonte permanente de dados e informações para a elaboração do relatório.

A pesquisa foi quantitativa, pois 0 pesquisador tinha conhecimento sobre 0 assunto, através da pesquisa exploratória feita anteriormente, que o levou a se familiarizar e aumentar seu conhecimento sobre o tema, o auxiliou a desenvolver a formulação do problema dessa pesquisa, assim como na criação das questões relevantes para atingir o objetivo pretendido além de clarificar conceitos. Na pesquisa exploratória foram utilizados os métodos de levantamento bibliográfico, documentais, de pesquisas efetuadas anteriormente e de experiências.

É importante ressaltar que o número significativo de questões abertas no instrumento de campo permitiu a exploração de opiniões dos entrevistados o que enriqueceu o estudo.

\section{Metodologia da pesquisa de campo}

Como a investigação foi sobre o processo comunicativo que ocorre entre os médicos e os pacientes em uma instituição pública, os públicos-alvo foram os médicos e os pacientes do Hospital do Servidor Público Estadual "Francisco Morato de Oliveira". A seguir as características dos médicos.

\footnotetext{
${ }^{52}$ DOWNS, C., Diagnosis through the questionnaire. Glenview, Illinois, Scott, Foresman and Company, p. 80-111.
} 


\section{Características dos médicos}

\section{Quadro no 1}

Perfil do médico

\begin{tabular}{|c|c|}
\hline Total de médicos entrevistados: & 88 \\
\hline \multirow{2}{*}{ Sexo: } & Masculino $(83,72 \%)$ \\
\hline & Feminino $(16,28 \%)$ \\
\hline Idade média: & 42 anos e 7 meses \\
\hline \multirow{4}{*}{ Estado civil: } & Casado (65,91\%) \\
\hline & Solteiro $(26,14 \%)$ \\
\hline & Divorciado $(6,82 \%)$ \\
\hline & Viúvo $(1,14 \%)$ \\
\hline \multirow{2}{*}{ Natural de (cidade): } & São Paulo (capital): 44,32\% \\
\hline & Demais cidades: $53,58 \%$ \\
\hline \multirow{5}{*}{ Onde reside: } & Zona sul $(70,45 \%)$ \\
\hline & Zona oeste $(13,64 \%)$ \\
\hline & Zona leste $(6,82 \%)$ \\
\hline & Zona norte $(2,27 \%)$ \\
\hline & Outros $(6,82 \%)$ \\
\hline \multirow{6}{*}{ Tempo de formado: } & De 20 a 40 anos de formado $(43,21 \%)$ \\
\hline & De 02 a 05 anos de formado $(23,87 \%)$ \\
\hline & De 10 a 20 anos de formado $(17,06 \%)$ \\
\hline & De 05 a 10 anos de formado $(7,96 \%)$ \\
\hline & Mais de 40 anos de formado $(6,82 \%)$ \\
\hline & Até 01 ano de formado $(1,14 \%)$ \\
\hline \multicolumn{2}{|c|}{ Especialização: } \\
\hline Com 1 especialidade & $88(100 \%)$ \\
\hline Com 2 especialidades & $13(14,77 \%)$ \\
\hline \multicolumn{2}{|c|}{ Mestrado: } \\
\hline Não tem mestrado & $72(81,82 \%)$ \\
\hline Tem mestrado & $9(10,23 \%)$ \\
\hline Em conclusão & $7(7,95 \%)$ \\
\hline Total & 88 \\
\hline
\end{tabular}




\begin{tabular}{|c|c|}
\hline \multicolumn{2}{|c|}{ Doutorado: } \\
\hline Não tem doutorado & $74(84,10 \%)$ \\
\hline Tem doutorado & $12(13,64 \%)$ \\
\hline Em conclusão & $2(2,27 \%)$ \\
\hline Total & 88 \\
\hline Não tem livre docência & $86(97,73 \%)$ \\
\hline Tem livre docência & $2(2,27 \%)$ \\
\hline Total & 88 \\
\hline
\end{tabular}

Para que haja uma melhor compreensão do perfil dos médicos, eles foram qualificados também quanto ao tempo de serviço, dias trabalhados e número de pacientes atendidos por dia, como segue:

\section{Características dos médicos quanto ao serviço}

\section{Tempo de serviço:}

Mínimo: menos de 1 ano. Máximo: 37 anos

Média: 13 anos e 11 meses

\section{Serviços pesquisados:}

Cardiologia, cirurgia geral, cirurgia vascular, clínica médica, fisiatria, ginecologia, gastrocirurgia e ortopedia. Foram pesquisados 8 dos 43 serviços existentes no Hospital do Servidor Estadual "Francisco Morato de Oliveira".

\section{Quantos dias trabalha por semana:}

Trabalha 5 a 7 dias por semana: $85,22 \%$

Trabalha até 4 dias por semana: 14,78\% 


\section{Quadro nº 2}

Horas trabalhadas por dia

\begin{tabular}{|l|c|c|}
\hline \multicolumn{2}{|c|}{ Horário: } \\
\hline 4 horas por dia & $54,55 \%$ & \multirow{2}{*}{ Total: $88,64 \%$} \\
\hline 8 horas por dia & $19,32 \%$ \\
\hline 10 horas por dia & $14,77 \%$ \\
\hline Outros & \multicolumn{2}{|c|}{$11,36 \%$} \\
\hline
\end{tabular}

Número de pessoas que atende:

Média diária, por médico: 12,8 pessoas

\section{Perfil do médico do Hospital do Servidor Público Estadual}

De um universo de 88 médicos, $83,72 \%$ são do sexo masculino e 16,28\% feminino. Pode-se inferir que o Hospital do Servidor Público Estadual tem em seus quadros um número maior de médicos do que médicas, isso foi confirmado quando pesquisados os serviços de gastrocirurgia, de cirurgia vascular e de ortopedia, onde a amostra é, exclusivamente, do sexo masculino.

A idade média dos entrevistados está em 42 anos e 7 meses. São médicos que estão atuando há pelo menos 20 anos, pois 43,21\% terminaram a graduação entre 20 e 40 anos atrás A média trabalhada no Hospital é de 13 anos e 11 meses. 85,22\% o fazem de 5 a 7 dias por semana e 14,78\% 4 dias, sendo que 54,55\% trabalha 4 horas por dia e 19,32\% 8 horas por dia. A média de atendimento diária é de 12,08 pacientes por dia.

Pela idade dos profissionais e também pelo tempo de desempenho na profissão, pode-se dizer que são médicos que têm grande experiência em suas especialidades, considerando também a demanda pelos seus serviços numa Instituição como é o Hospital do Servidor Público Estadual que realizou, em 1998, um total de 1.108.754 consultas, resultando em 3.077 consultas diárias, que daria 3,8 consultas para cada um dos 800 médicos, caso todos eles trabalhassem todos os 365 dias do ano. Como existe 
uma variação da quantidade de horas e dias trabalhados, o que se tem é apenas uma média de pacientes atendidos, que está perfeitamente dentro dos padrões estabelecidos pelo Conselho Regional de Medicina.

A maioria é casada (65,91\%), são naturais da cidade de São Paulo (44,32\%) e a grande maioria reside na Zona Sul (70,45\%), onde se localiza o Hospital. Pode-se supor que esse fato se deva aos horários de trabalho normal e também aos plantões, que também acontecem em horários diversificados e que esses profissionais buscam reduzir as dificuldades de acesso para se chegar ao Hospital, considerando o trânsito sempre caótico de São Paulo.

Quanto à especialização, apenas 19,32\% têm duas especializações. 81,82\% não têm mestrado; 10,23\% têm; e 7,95\% estão concluindo. Deles, 84,10\% não têm doutorado; 13,64\% têm; 2,27\% estão concluindo. Apenas 2,27\% têm livre docência.

O estudo realizado pela Fundação Oswaldo $\mathrm{Cruz}^{53}$, sobre o perfil dos médicos brasileiros, demonstrou que $80 \%$ deles consideram a atividade médica desgastante, sendo os principais fatores: excesso de trabalho/multiemprego, baixa remuneração, más condições de trabalho, responsabilidade profissional, área de atuação/especialidade, relação médico-paciente, conflito/cobrança da população e perda da autonomia. Neste quadro, dificilmente esse profissional teria condições, principalmente que se refere ao fator tempo, de conseguir atualizar-se através de longos cursos acadêmicos, como demandam o mestrado, doutorado e a livre-docência.

A seguir a caracterização dos pacientes, para que se possa entender como são esses receptores e emissores no processo de comunicação ora analisado.

\footnotetext{
${ }^{53}$ MACHADO, M.H, op. cit.
} 


\section{Características dos pacientes}

\section{Quadro no 3}

Perfil dos pacientes

\begin{tabular}{|c|c|}
\hline Total de pacientes entrevistados: & 152 \\
\hline \multirow{2}{*}{ Sexo: } & Feminino $(65,79 \%)$ \\
\hline & Masculino (34,21\%) \\
\hline Idade média: & 51 anos e 10 meses \\
\hline \multirow{5}{*}{ Estado civil: } & Casado (62,50\%) \\
\hline & Solteiro $(17,11 \%)$ \\
\hline & Viúvo $(13,16 \%)$ \\
\hline & Divorciado $(5,92 \%)$ \\
\hline & Outros $(1,32 \%)$ \\
\hline \multirow{2}{*}{ Natural de (cidade): } & São Paulo (capital): 36,84\% \\
\hline & Demais cidades: $63,16 \%$ \\
\hline \multirow{6}{*}{ Onde reside: } & Zona sul $(29,61 \%)$ \\
\hline & Outros $(29,61 \%)$ \\
\hline & Zona leste $(21,71 \%)$ \\
\hline & Zona norte $(9,21 \%)$ \\
\hline & Zona oeste $(8,55 \%)$ \\
\hline & Centro $(1,32 \%)$ \\
\hline \multirow{6}{*}{ Escolaridade: } & Primário $(32,24 \%)$ \\
\hline & Colegial $(25,66 \%)$ \\
\hline & Superior $(23,68 \%)$ \\
\hline & Segundo grau $(11,84 \%)$ \\
\hline & Superior incompleto $(3,29 \%)$ \\
\hline & Não alfabetizado (1,97\%) \\
\hline
\end{tabular}

Foi também traçado o seu perfil quanto às suas atividades profissionais: 


\section{Quadro no 4}

Atividade profissional do paciente

\begin{tabular}{|c|c|}
\hline \multicolumn{2}{|c|}{ Funcionário: } \\
\hline Ativo & $45,39 \%$ \\
\hline Dependente & $40,79 \%$ \\
\hline Aposentado Órgão em que trabalha: \\
\hline \multicolumn{2}{|c|}{$13,16 \%$} \\
\hline Secretaria da Educação & $33,55 \%$ \\
\hline Outros & $66,45 \%$ \\
\hline \multicolumn{1}{|c|}{ Função: } \\
\hline Professor(a) & $25,00 \%$ \\
\hline Outros & $75,00 \%$ \\
\hline Tempo médio de serviço: 13 anos e 6 meses \\
\hline Média de tempo que usa os serviços médicos do Hospital: 10 anos e 3 meses \\
\hline Nem outro plano de saúde: \\
\hline Sim & $87,50 \%$ \\
\hline
\end{tabular}

\section{Perfil do paciente do Hospital do Servidor Público Estadual}

Dos 152 pacientes entrevistados, $65,79 \%$ são do sexo feminino e $34,21 \%$ masculino, comprovando assim a afirmativa dos médicos quanto ao gênero dos seus pacientes no Hospital. A idade média é de 51 anos e 10 meses, são casados (62,50\%) e apenas $36,84 \%$ são naturais da capital, sendo $63,16 \%$ de outras cidades. Apenas $29,61 \%$ residem na zona sul.

A escolaridade tem maior expressividade no primário com 32,24\%; $25,66 \%$ têm o colegial; e 23,68\%, curso superior. Esse último dado, referente ao curso superior, surpreendeu, pois, segundo os médicos, a escolaridade dos seus pacientes é baixa.

Percebe-se, no estudo, que a maioria dos pacientes já ultrapassou os 50 anos, idade na qual o paciente requer maiores cuidados, principalmente os do sexo feminino, pois é nessa idade que aparecem problemas ligados à menopausa, osteoporose etc. 
45,39\% são funcionários ativos, 40,79\% são dependentes e 13,16\% aposentados; sendo 33,55\% da Secretaria da Educação e 66,45\% de outros órgãos públicos. $25,00 \%$ são professores e $75,00 \%$ têm outras atividades. O tempo médio de serviço dos pesquisados está em 13 anos e 6 meses.

Diferentemente dos dados das pesquisas realizadas pelo Departamento de Convênios e Assistência Médica Ambulatorial - DECAM ${ }^{54}$, do IAMSPE, no qual a idade da maioria dos usuários é de 60 anos, o estudo apontou para uma idade menor, mas houve uma confirmação quanto ao gênero feminino, o órgão de trabalho e a profissão.

Dos 152 pacientes, 87,50\% não têm outro plano de saúde; apenas 12,50\% disseram que sim; utilizam os serviços do Hospital há 10 anos e 3 meses, tempo médio.

O serviço de saúde pública paulista, apesar de atravessar uma fase difícil na área econômica e institucional, tem recebido um número crescente de usuários que, por várias questões, não tem condições de pagar um serviço de saúde privado.

$\mathrm{Na}$ impossibilidade de se pesquisar os 43 serviços existentes no Hospital do Servidor Estadual "Francisco Morato de Oliveira" foram elegidos 8 desses serviços.

\section{Serviços pesquisados, tanto para os médicos quanto para os pacientes}

Cardiologia, cirurgia geral, cirurgia vascular, clínica médica, fisiatria, ginecologia, gastrocirurgia e ortopedia. É importante que se faça um breve relato sobre a representatividade desses serviços, para que se entenda o porquê dessa escolha.

\section{Representatividade desses serviços:}

\section{* Cardiologia}

Serviço com grande demanda, visto a alta faixa etária dos pacientes atendidos no Hospital, representada principalmente pelos aposentados e pelos ascendentes dos funcionários.

\footnotetext{
${ }^{54}$ JORNAL DO IAMSPE, op. cit.
} 


\section{* Cirurgia geral}

Responsável por todas as urgências cirúrgicas do Pronto Socorro e do Hospital (enfermarias). Sua atuação é ampliada por socorrer também a maioria dos pacientes com necessidade de pequenas cirurgias.

\section{- Cirurgia vascular}

Alta demanda pelo grande número de pacientes com patologia de varizes e arteriais dos membros inferiores (idosos e diabéticos).

\section{* Clínica médica}

É o serviço de maior demanda, pois é a primeira procura do paciente no Hospital e, além disso, engloba todos os problemas de resolução rápida (gripes, etc.). Atende a demanda reprimida de todos os outros serviços.

\section{Fisiatria}

Tem grande importância por atender ao enorme número de pacientes com seqüelas de AVSs (derrames) e a recuperações de casos ortopédicos.

\section{- Ginecologia}

Alta demanda em vista do grande índice de adultos e funcionárias atendidas no Hospital e também dos seus dependentes - esposas, mães, filhas - com direito à assistência.

\section{* Gastrocirurgia}

Responsável pelo maior número de patologias cirúrgicas (abdômen - trato digestivo) de rotina. Atende a poucos pacientes de urgência devido ao atendimento da cirurgia geral.

\section{* Ortopedia}

Extremamente importante por ser responsável pelo atendimento de pacientes que sofreram acidentes ou quedas com fraturas. Responde também pela maioria das doenças profissionais de afastamento de trabalho. 


\section{A pesquisa de campo (médicos)}

A seguir detalhes de como foram realizados os trabalhos de campo, tanto dos médicos quanto dos pacientes.

As pesquisas com os médicos foram realizadas nos ambulatórios e enfermarias. Consideramos que o ambiente onde o médico atende ao paciente é um aspecto relevante, pois todas as causas que interferem no atendimento estarão presentes na sua memória, assim como os efeitos e, portanto, suas respostas estarão contaminadas por todos os estímulos que ali se apresentam. Isso, por exemplo, evitou que houvesse a manipulação de variáveis controláveis, como o barulho rotineiro e muitos pacientes para atender. Procuramos evitar a ocorrência de viéses advindos destas e outras causas.

As listas dos serviços pesquisadas, fornecidas pela Diretoria do Centro de Recursos Humanos do Hospital "Francisco Morato de Oliveira", foram, de uma forma geral, todas elas esgotadas.

Pode-se perceber, pelas tabelas abaixo, os resultados numéricos e percentuais dos médicos e serviços pesquisados.

\section{Quadro no 5}

Médicos entrevistados

\begin{tabular}{|c|c|}
\hline Total de médicos do Hospital & 784 \\
\hline Total de médicos entrevistados & $88(11,77 \%)$ \\
\hline Total de serviços do Hospital & 43 \\
\hline Total de serviços pesquisados & $8(18,61 \%)$ \\
\hline
\end{tabular}




\section{Quadro no 6}

Serviços pesquisados

\begin{tabular}{|c|c|c|c|c|}
\hline Serviços & Total de médicos & $\begin{array}{c}\text { Médicos } \\
\text { entrevistados }\end{array}$ & \% quanto aos 88 & $\begin{array}{c}\text { \% quanto ao } \\
\text { serviço }\end{array}$ \\
\hline Cardiologia & 26 & 17 & 19,32 & 65,36 \\
\hline Cirurgia Geral & 20 & 14 & 15,91 & 56,00 \\
\hline Ortopedia & 22 & 14 & 15,91 & 63,64 \\
\hline Clínica Médica & 23 & 12 & 13,64 & 52,17 \\
\hline Ginecologia & 43 & 12 & 13,64 & 27,91 \\
\hline Gastrocirurgia & 21 & 8 & 9,10 & 39,10 \\
\hline Cirurgia Vascular & 17 & 7 & 7,96 & 41,18 \\
\hline Fisiatria & 6 & 4 & 4,55 & 66,67 \\
\hline
\end{tabular}

\section{Tipo de amostragem}

Para a escolha do processo de amostragem, foi preciso levar em conta o tipo de pesquisa, a acessibilidade da população, a disponibilidade ou não de se terem listados os elementos da população, a representatividade desejada ou necessária, a disponibilidade de tempo, dos recursos financeiros e humanos etc. Cumprida essa etapa, optou-se por uma amostra não probabilística e por quota.

A meta era uma amostra de médicos e serviços que representasse a totalidade da categoria do Hospital do Servidor Público "Francisco Morato de Oliveira". É conveniente que se citem as restrições encontradas.

- Não foi possível o acesso ao número de médicos das demais 35 especialidades.

- A lista disponibilizada pela Diretoria do Centro de Recursos Humanos do Hospital continha discrepância entre os horários reais e os oficias de trabalho desses profissionais.

- O período de realização do estudo (pesquisa de campo) foi estipulado em 90 dias pela Diretoria do Hospital. Após esse período, os entrevistadores não teriam mais autorização de acesso aos ambulatórios e enfermarias.

- Elevado custo para desenvolvimento da pesquisa. 
A maioria da amostra foi composta por médicos, com apenas dois casos de residentes. As pesquisas foram realizadas nos períodos da manhã e da tarde, em horário compreendido entre às $7.30 \mathrm{~h}$ e $17.00 \mathrm{~h}$, de segunda às sextas-feiras, de 15 de julho a 15 de outubro.

\section{A pesquisa de campo (pacientes)}

Naturalmente não havia uma lista de nomes de pacientes, como no caso dos médicos. Havia aqui uma variável diferente das do médico: o paciente podia achar que sua privacidade estava sendo invadida e a abordagem precisou ser cuidadosa para que os resultados fossem adequados.

Pesquisou-se os mesmos serviços onde estavam sendo entrevistados os médicos.

A amostragem, como no caso dos médicos, foi não probabilística e por quotas. Procurou-se obter uma amostra de pacientes que representasse a totalidade de pacientes do Hospital do Servidor Público "Francisco Morato de Oliveira".

O procedimento para abordar o paciente seguiu esses passos: era feita a contagem de 1 a 3 , e o terceiro paciente a sair do ambulatório de uma das especialidades citadas acima era interpelado pelo pesquisador. Se o paciente tivesse condições para responder ao questionário e quisesse fazê-lo, o pesquisador dava seqüência ao seu trabalho. Caso contrário recomeçava a contagem do 1 (um) novamente.

Foram trabalhadas cada uma das especialidades por vez, tentando-se obter as quotas propostas. Esse critério foi estabelecido porque as especialidades elegidas ficam em andares diferentes do Hospital, num total de 15, e havia um único entrevistador. Deixou-se estabelecer a tendência e, quando verificávamos que alguma especialidade ainda não estava representada, aquele serviço era procurado para preencher todas as quotas.

As pesquisas foram realizadas nos ambulatórios, no ambiente de atendimento do respondente. Considerou-se esse contexto relevante, pois todos os fatores que interferem no atendimento estariam influindo nos seus procedimentos e emoções. 
Isso evitou que houvesse a manipulação de variáveis controláveis como, por exemplo, a espera decorrente de muitos pacientes para um único médico atender. Evitou-se a ocorrência de viéses advindo desta e de outras causas.

Foram realizadas 152 entrevistas assim distribuídas:

\section{Quadro no 7}

Número de pacientes entrevistados por serviço

\begin{tabular}{|c|c|c|}
\hline Serviços & Pacientes entrevistados & \% quanto aos 152 \\
\hline Cardiologia & 20 & 13,16 \\
\hline Cirurgia Geral & 20 & 13,16 \\
\hline Ortopedia & 20 & 13,16 \\
\hline Fisiatria & 19 & 12,50 \\
\hline Ginecologia & 19 & 12,50 \\
\hline Gastrocirurgia & 19 & 12,50 \\
\hline Cirurgia Vascular & 18 & 11,84 \\
\hline Clínica Médica & 17 & 11,18 \\
\hline
\end{tabular}

\section{Critério para escolha dos pacientes}

A condição para que o paciente fosse entrevistado era que tivesse sido atendido em um dos seguintes serviços: cardiologia, cirurgia geral, cirurgia vascular, clínica médica, fisiatria, ginecologia, gastrocirurgia e ortopedia.

\section{Trajetória da pesquisa}

O primeiro passo foi definir como objeto de estudo o processo comunicativo que ocorre entre o médico e o paciente, no momento da consulta, numa instituição pública. Optou-se pelo Hospital do Servidor Público "Francisco Morato de Oliveira", tanto pela probabilidade de autorização para realizar a pesquisa de campo quanto pela viabilidade que se poderia ter na obtenção de dados. Havia o conhecimento que eram necessárias facilidades técnicas e burocráticas para realizar esse estudo. 
Em um segundo momento, era preciso selecionar quais instrumentos seriam mais adequados para identificar essa comunicação, levando-se em consideração as particularidades daquela instituição e também a disponibilidade de tempo, de recursos humanos e financeiros, e o quanto seria necessário.

Em uma terceira etapa, fez-se o levantamento bibliográfico, buscando os fundamentos teóricos, os trabalhos e as pesquisas que tivessem como foco a comunicação médico \& paciente. Constatou-se que os profissionais da psiquiatria e psicologia são o que se destacam no estudo e pesquisa sobre essa temática, com uma contribuição significativa sobre o assunto.

A quarta etapa, que foi concomitante com a terceira, ocorreu no Hospital. Foi feito o levantamento de experiências com o corpo clínico, para descobrir qual seria a melhor metodologia para pesquisar a comunicação que ocorria quando estavam em consulta naquela Instituição. Muitos médicos acumulam experiências e conhecimentos sobre o tema e suas informações foram extremamente pertinentes para o estudo. Usou-se a técnica da entrevista individual. Foram entrevistados 8 médicos, as respostas foram devidamente anotadas e depois foi feita uma análise das mesmas, buscando-se as similaridades e diferenças de opiniões.

Colheu-se também, em uma quinta etapa, depoimentos de amigos/pacientes, que tinham sido atendidos em hospitais públicos paulistas, com o intuito de buscar nesse público experiências que pudessem auxiliar nas respostas às indagações de como seria a comunicação dos pacientes com os médicos. Aqui também foi utilizada a técnica da entrevista individual e anotadas as respostas. Foram entrevistados 15 pacientes.

Posteriormente, foram consultados professores de Estatística, do Instituto de Matemática e Estatística - IME - da Universidade de São Paulo, onde foi confirmada a opinião de que o questionário seria o instrumento mais adequado para o estudo de caso, tanto pela facilidade de aplicação e rapidez de se obter os dados necessários, como também por ser o de custo mais acessível.

Foi então feito o levantamento dos dados para caracterização da população alvo assim como a determinação da amostra a ser analisada, segundo critérios de estatística sugeridos pelo IME. O pré-teste foi feito pelo supervisor e mais dois 
pesquisadores, nos serviços de cardiologia, cirurgia geral, cirurgia vascular, clínica médica, fisiatria, ginecologia, gastrocirurgia e ortopedia.

Após esse procedimento, os questionários dos médicos e dos pacientes foram ajustados para corrigir as falhas detectadas e então foi iniciada a aplicação dos mesmos nos serviços citados.

Na tabela abaixo, temos os serviços pesquisados, o total numérico de médicos entrevistados de cada serviço e o percentual de cada especialidade com relação à amostra total de médicos.

\section{Amostragem dos médicos}

\section{Quadro no 8}

Número de médicos entrevistados por serviço

\begin{tabular}{|c|c|c|}
\hline Serviços & Médicos entrevistados & \% quanto aos 88 \\
\hline Cardiologia & 17 & 19,32 \\
\hline Cirurgia Geral & 14 & 15,91 \\
\hline Ortopedia & 14 & 15,91 \\
\hline Clínica Médica & 12 & 13,64 \\
\hline Ginecologia & 12 & 13,64 \\
\hline Gastrocirurgia & 8 & 9,10 \\
\hline Cirurgia Vascular & 7 & 7,96 \\
\hline Fisiatria & 4 & 4,55 \\
\hline
\end{tabular}

Estão delineadas a seguir quais foram as etapas para se atingir essa amostragem:

A partir de uma lista de nomes de médicos das especialidades já referidas, fornecida pela Diretoria do Centro dos Recursos Humanos do Hospital, foram contatados os Diretores dos respectivos serviços, que autorizaram as pesquisas. 
Isso foi necessário, já que seria considerado politicamente incorreto os médicos serem abordados sem o consentimento do Diretor ao qual se reportam.

$>$ O critério estabelecido foi de que seriam abordados os médicos que estivessem disponíveis para responder ao questionário, no período da realização do trabalho, em um horário compreendido entre as $7.30 \mathrm{~h}$ às $17.00 \mathrm{~h}$, e que as pesquisas fossem realizadas no Hospital. Todas as listas foram esgotadas para se atingir a amostra pesquisada.

As 88 entrevistas, dentro das especialidades citadas, foram feitas por um único entrevistador, sob supervisão.

\section{Amostragem dos pacientes}

Foram feitas 152 entrevistas, dentro das oito especialidades mencionadas, por um único entrevistador, sob supervisão.

\section{Coleta de Dados}

O instrumento utilizado na coleta de dados, tanto para os médicos como para os pacientes, foi o questionário, dos quais constaram questões abertas, fechadas e semiabertas. (Vide anexos no 2 e 3)

As variáveis de segmentação procuraram mostrar o perfil do médico e do paciente do Hospital "Francisco Morato de Oliveira" e como se desenvolve o processo comunicativo na interação entre esses dois agentes.

\section{Os médicos:}

a) Quanto à identificação: sexo, idade, estado civil, natural de, conclusão da graduação, especialização, mestrado e doutorado. Tempo de serviço no IAMSPE;

b) Quanto à caracterização do serviço: quantos dias trabalha no Hospital, horário de trabalho, como é o atendimento dentro do consultório, quantas pessoas atende por dia, tempo da consulta. 


\section{Os pacientes:}

a) Quanto à identificação: sexo, idade, estado civil, natural de, zona onde reside, escolaridade, se é funcionário ativo, função;

b) Quanto ao atendimento no Hospital: há quanto tempo usa esse serviço, tempo de espera, tempo de consulta.

\section{Temática dos questionários}

As perguntas foram esquematizadas de modo a facilitar a análise subseqüente, porque se pretendia extrair as informações diretamente dos questionários. Isso se refere tanto para os dados quantitativos quanto qualitativos.

Explorou-se aspectos da comunicação que ocorre entre o médico e o paciente, dentro do consultório, tentando definir:

a) o que o médico entendia como uma boa comunicação e atendimento;

b) o que poderia ser feito para melhorar essa comunicação;

c) o que o paciente representava para o médico e o que o mesmo esperava dele;

d) explorou-se também a tensão e as expectativas do paciente nesses momentos.

Os aspectos abordados foram os da comunicação que ocorre entre o paciente e o médico, dentro do ambulatório, tentando definir:

a) o que o paciente entendia como uma boa comunicação e atendimento;

b) o que poderia ser feito para melhorar essa comunicação;

c) o que o médico representava para ele e o que o paciente achava que representava para o médico.

Em 15 de julho de 1998 foi iniciado o pré-teste nos serviços de cardiologia, cirurgia geral, cirurgia vascular, clínica médica, fisiatria, ginecologia, gastrocirurgia e ortopedia. Começava aqui o contato físico com o Hospital e com tudo que é inerente a uma Instituição de saúde pública: os seus diversos públicos e as situações decorrentes de uma política de pouco investimento nesse setor e as implicações dessa postura, que têm sido mostrada quase que diariamente pela mídia: excesso de pacientes e poucos médicos para atendê-los. 


\section{Abordagem ao médico}

Era explicado ao respondente que se tratava de um estudo de caso no Hospital do Servidor Público "Francisco Morato de Oliveira", para se verificar como era a comunicação do médico \& paciente, dentro do consultório. Procurou-se isenção em relação ao objetivo da pesquisa. O entrevistador identificava-se como sendo da Universidade de São Paulo e indagava se o médico tinha tempo e vontade para responder ao questionário, o que demorava em média 10 minutos. O questionário era preenchido pelo pesquisador.

\section{Abordagem ao paciente}

Era explicado ao respondente que se tratava de um estudo de caso no Hospital do Servidor Público "Francisco Morato de Oliveira", para se verificar como era a comunicação do paciente \& médico, dentro do consultório. Procurou-se isenção ou relação com o objetivo da pesquisa. $O$ entrevistador identificava-se como sendo da Universidade de São Paulo e indagava se o paciente tinha tempo e vontade para responder ao questionário, o que demorava em média 10 minutos. Como o nível de escolaridade era diversificado, usou-se uma linguagem compatível ao do respondente. O questionário era preenchido pelo pesquisador.

\section{A equipe}

A equipe de entrevistadores contou com um supervisor e dois pesquisadores, ambos graduandos da Universidade de São Paulo. Foi feito o treinamento dos mesmos, visando conseguir uniformidade na forma de aplicação dos questionários. 


\section{Metodologia da análise dos dados do instrumento}

Checagem dos dados (acompanhamento da aplicação dos questionários)

A checagem dos dados fornecidos pelos médicos foi feita pelo supervisor, usando a seguinte sistemática: a título de agradecimento por responder ao questionário, telefonava para 0 médico, abordava então algumas respostas confirmando os dados que pudessem ou não ter dúbias interpretações.

A checagem dos dados fornecidos pelos pacientes foi feita pelo supervisor in loco, periodicamente e em intervalos não programados.

\section{Crítica aos questionários}

A verificação do instrumento aplicado no campo se preocupou em apurar se o questionário estava completo, legível e compreensível, consistente e preciso. $A$ verificação foi sistemática.

Completo: verificou-se se todas as questões foram respondidas;

Legível e compreensível: para que o dado fosse posteriormente codificado, era preciso que tivesse sido claramente registrado no instrumento e que as palavras utilizadas fossem compreensíveis. Caso o registro estivesse ilegível ou incompreensível, poderia ser corrigido através de contato com o entrevistador responsável;

Consistente: a consistência diz respeito à existência de coerência entre as respostas das diferentes questões do questionário. Não era consistente o instrumento que, por exemplo, apresentasse hábitos socioculturais incompatíveis com o nível educacional do respondente. Caso isso acontecesse, o supervisor solicitava esclarecimentos ao entrevistador e, se estes não fossem satisfatórios, eliminava as questões sem consistência.

Preciso: o supervisor esteve atento para descobrir possíveis imprecisões nos dados. Essas imprecisões poderiam estar relacionadas a viéses introduzidos pelos entrevistadores ao conduzir de forma errônea a entrevista e aos originários da falta de colaboração dos respondentes. 
Sistemática: procedimento para complementar dados que porventura faltassem. Foi feito logo após as entrevistas.

\section{Codificação}

A codificação é o procedimento técnico pelo qual os dados são categorizados. Através da codificação, os dados brutos foram transformados em símbolos necessariamente numéricos porque foi utilizado o processamento eletrônico - que foram contados e tabulados. Os procedimentos para codificação foram diferentes para respostas a serem codificadas, dependia se eram questões abertas ou fechadas.

As bases para codificação do instrumento muitas vezes se apoiaram em informação conseguida durante o pré-teste e incluíram as principais alternativas de respostas relevantes para os objetivos da pesquisa.

A disposição das perguntas do questionário permitiu que a codificação fosse feita com certa facilidade pelo entrevistador.

\section{A relevância das questões abertas}

As perguntas abertas, também conhecidas como "de resposta livre", envolvem uma resposta de mais do que algumas palavras.

Estabelecia-se o assunto para o respondente - no caso a comunicação médico \& paciente - que estruturou a resposta que achou melhor. $O$ respondente teve grande liberdade para formular a resposta, que pode ser de grande extensão e com muitos detalhes, com suas próprias palavras. Esperou-se que o entrevistador registrasse palavra por palavra do que estava sendo respondido.

Existiu o risco do entrevistador introduzir um viés pelo registro inexato do que ouviu. Deliberadamente ou não, o entrevistador pode anotar apenas parte da resposta, e este registro seletivo talvez não represente adequadamente a resposta completa. 
Quase sempre é difícil comprimir as respostas dadas livremente em um número limitado de códigos; esta dificuldade pode ser reduzida pela experiência ganha durante o pré-teste, que facilitou a redação das principais classificações de respostas.

\section{A codificação das respostas abertas}

\section{Essa fase do trabalho foi realizada em conjunto com a equipe da Fundação Instituto de Administração - FIA USP.}

Foi feita a digitação integral das respostas abertas, com identificação dos questionários, numerados de 1 a 88 , no caso dos médicos, e de 1 a 152, no caso dos pacientes.

Havia uma preocupação tanto com a extensão quanto com a diversidade de respostas. Algumas mais extensas e com vários significados trouxeram alguns problemas. Mantendo-se as diversas respostas, não haveria concentração alguma. Já, se "forçasse" uma concentração, perder-se-iam muitos detalhes.

Assim, para esses casos, como foi com as questões em que se pediam 3 atributos ou fatores, foi utilizada uma metodologia que, apesar de trabalhosa, daria: a concentração necessária, a possibilidade de análise e o detalhamento dos códigos.

Primeiramente foram consideradas todas as diferentes respostas. Agrupou-se então as que tinham similaridade de conteúdo. Foi feita a escolha de uma palavrachave que caracterizasse esses agrupamentos. Atribuíram-se códigos secundários para cada palavra-chave. Em seguida, agruparam-se esses diferentes códigos secundários em grupos maiores, ou seja, em códigos primários. Esse método funciona regressivamente, pois parte-se de um universo de opiniões diversificadas, que, no primeiro momento são agrupadas por similaridades, recebendo cada grupo uma palavra-chave como título. Essa palavra tem um significado que "traduz" todas as respostas daquele grupo. Numa segunda etapa, dá-se um código numérico para a palavra-chave. Esse código é denominado código secundário. Em uma terceira etapa, agrupam-se os códigos secundários que são afins e dá-se um código primário. 
A partir dessa etapa, tem-se um número bem menor de códigos, pois os primários abrigam vários secundários.

Ao utilizar códigos primários, que são em menor número, e secundários que demandam maior quantidade de códigos numéricos, consegue-se o objetivo de preservar os detalhes e permitir a análise estatística.

Dessa maneira, obtêm-se, tanto a freqüência dos códigos primários, quanto à possibilidade de, a qualquer momento, se abrir esses códigos para se verificar a composição e freqüência dos códigos secundários. As respostas da questão 22 , do questionário do médico, ilustram bem a metodologia utilizada.

Exemplo:

\section{Quadro n 9}

Atributos para um bom atendimento ao paciente - respostas com respectivos códigos

\begin{tabular}{|c|l|c|c|c|}
\hline \multicolumn{4}{|c|}{ Questão 22 - Cite 3 atributos para um bom atendimento ao paciente } \\
\hline $\begin{array}{c}\text { No do } \\
\text { Questionário }\end{array}$ & \multicolumn{2}{|c|}{ Códigos } \\
\hline 51 & $\begin{array}{l}\text { Melhor atendimento que o paciente tem, que o médico saiba } \\
\text { informar o que ele tem, confiabilidade }\end{array}$ & 10 & 40 & 24 \\
\hline 32 & Boa anamnese, exame, encaminhamento & 11 & 13 & 14 \\
\hline 62 & Boa história, bom exame físico, empatia & 11 & 13 & 28 \\
\hline 69 & $\begin{array}{l}\text { Boa conversa (anamnese), bom relacionamento } \\
\text { médico/paciente, respeito mútuo }\end{array}$ & 11 & 21 & 27 \\
\hline 82 & $\begin{array}{l}\text { Realização de anamnese completa, esclarecimento dos } \\
\text { aspectos para o doente e proposição de um tratamento mais } \\
\text { eficaz }\end{array}$ & 12 & 42 & \\
\hline 18 & Avaliação completa do paciente, condições de trabalho & 12 & 50 & \\
\hline 67 & $\begin{array}{l}\text { Conseguir realizar o que o paciente espera fazer bom } \\
\text { diagnóstico e boa conduta }\end{array}$ & 14 & 12 & 14 \\
\hline 85 & Queixa seja bem identificada, diagnóstico e conduta precisa & 14 & 12 & 14 \\
\hline 70 & $\begin{array}{l}\text { Não esperar para ser atendido, ser examinado e retornos } \\
\text { freqüentes }\end{array}$ & 14 & 13 & 14 \\
\hline 59 & $\begin{array}{l}\text { Satisfação do paciente, compreensão dele, atendimento dentro } \\
\text { do horário }\end{array}$ & 14 & 22 & 10 \\
\hline 30 & Pontualidade, respeito, desburocratização & 14 & 27 & 50 \\
\hline 10 & $\begin{array}{l}\text { Prontuário, o paciente precisa esclarecer o que ele tem, sem } \\
\text { pressão no atendimento }\end{array}$ & 14 & 42 & 80 \\
\hline
\end{tabular}




\begin{tabular}{|c|c|c|c|c|}
\hline 03 & $\begin{array}{l}\text { Atenção ao paciente, bom exame clínico e explicações } \\
\text { inteligíveis }\end{array}$ & 20 & 13 & 42 \\
\hline 14 & Atenção, paciência, orientação & 20 & 26 & 42 \\
\hline 72 & Atenção, conhecimento, dedicação & 20 & 31 & 25 \\
\hline 78 & Atenção, delicadeza e compreensão & 20 & 295 & 22 \\
\hline 76 & Atenção, carinho e dedicação & 20 & 295 & 25 \\
\hline 26 & Boa relação médico-paciente, atenção, bom diagnóstico & 21 & 20 & 12 \\
\hline 66 & Bom relacionamento, conhecimento, auxílio do HSPE & 21 & 31 & 50 \\
\hline 77 & Boa vontade, simpatia, dedicação, amor & 22 & 28 & 25 \\
\hline 41 & Educação, atenção e possível solução & 23 & 20 & 70 \\
\hline 38 & Educação, paciência humildade & 23 & 26 & 295 \\
\hline 02 & Boa educação, explicação correta, tempo para ouvir o paciente & 23 & 42 & 80 \\
\hline 33 & $\begin{array}{l}\text { Se apresentar ao paciente, tratá-lo pelo nome, ouvir bem o que } \\
\text { ele tem a dizer, explicar e orientar adequadamente sobre a } \\
\text { doença }\end{array}$ & 23 & 43 & 42 \\
\hline 22 & $\begin{array}{l}\text { Segurança, realização de exames, garantia de solução para o } \\
\text { problema }\end{array}$ & 24 & 13 & 70 \\
\hline 17 & $\begin{array}{l}\text { Confiança no médico, compreensão, exame adequado, } \\
\text { satisfação do paciente }\end{array}$ & 24 & 22 & 14 \\
\hline 46 & Confiança, transparência dos dois lados & 24 & 29 & \\
\hline 71 & Confiança, esclarecer o diagnóstico e tratamento & 24 & 42 & 14 \\
\hline 74 & Paciência, competência, fazer cara de anjo & 26 & 30 & 295 \\
\hline 13 & $\begin{array}{l}\text { Empatia, a atenção do médico, poder de comunicação do } \\
\text { médico }\end{array}$ & 28 & 20 & 40 \\
\hline 11 & Simpatia, confiança e conhecimento & 28 & 24 & 31 \\
\hline 60 & $\begin{array}{l}\text { Sinceridade do paciente, paciência e disponibilidade para ouvir, } \\
\text { vontade de resolver o problema do paciente }\end{array}$ & 29 & 26 & 70 \\
\hline 47 & $\begin{array}{l}\text { Honestidade do médico no exercício profissional, competência } \\
\text { técnica, interesse do médico pelo paciente ao atendê-lo, com } \\
\text { vista a solucionar os problemas dele, diagnosticar com precisão } \\
\text { os seus problemas e buscar a melhor terapêutica possível }\end{array}$ & 29 & 30 & 25 \\
\hline 48 & Honestidade, competência e efetividade & 29 & 30 & 70 \\
\hline 86 & Conhecimento, boa vontade, atenção ao paciente & 31 & 22 & 20 \\
\hline 83 & Conhecimento da especialidade, experiência e bom senso & 31 & 295 & \\
\hline 43 & Precisão, caloroso, eficiente & 31 & 295 & 70 \\
\hline 87 & Falar no nível do paciente, fazer bom exame físico & 40 & 13 & \\
\hline 54 & $\begin{array}{l}\text { Ter comunicação franca e simpática, ser competente e saber } \\
\text { orientar o doente }\end{array}$ & 40 & 30 & \\
\hline 39 & Comunicação, diálogo, respeito, diagnóstico certo & 40 & 41 & 27 \\
\hline
\end{tabular}




\begin{tabular}{|c|c|c|c|c|}
\hline 84 & Saber se expressar, ambiente, tempo & 40 & 60 & 80 \\
\hline 36 & $\begin{array}{l}\text { Diálogo, bom exame físico, adequar o medicamento às } \\
\text { condições do paciente }\end{array}$ & 41 & 13 & 14 \\
\hline 08 & Conversar, bom exame clínico, boa solução & 41 & 13 & 70 \\
\hline 53 & Ouvir e examinar bem o paciente & 43 & 13 & \\
\hline 12 & $\begin{array}{l}\text { Saber ouvir, saber examinar e diagnosticar, saber fazer a } \\
\text { devolução }\end{array}$ & 43 & 13 & 14 \\
\hline 19 & Ouvir bem, examiná-lo bem, explicação, confiança & 43 & 13 & 24 \\
\hline 79 & $\begin{array}{l}\text { Ouvi-lo com atenção, examiná-lo com tranqüilidade, conversar, } \\
\text { esclarecendo-o sobre o problema }\end{array}$ & 43 & 13 & 41 \\
\hline 07 & Ouvir queixas clínicas, fazer bom exame, explicar direito & 43 & 13 & 42 \\
\hline 25 & Saber ouvir, calma, competência & 43 & 26 & 30 \\
\hline 06 & Saber ouvir, ter conhecimento técnico, boa vontade & 43 & 31 & 22 \\
\hline 29 & Ouvir bem, troca de informações & 43 & 40 & \\
\hline 04 & Ouvir bem a queixa, saber interpretar e diagnosticar certo & 43 & 40 & 12 \\
\hline 73 & $\begin{array}{l}\text { Escutar o que o doente tem a dizer, usar linguagem leiga, } \\
\text { escrever legível }\end{array}$ & 43 & 40 & 40 \\
\hline 34 & Ouvir o paciente, responder as dúvidas, tirar a ansiedade & 43 & 44 & 295 \\
\hline 57 & $\begin{array}{l}\text { Escutar as queixas, saber seus medos, bom diagnóstico, boa } \\
\text { orientação }\end{array}$ & 43 & 295 & 12 \\
\hline 75 & $\begin{array}{l}\text { Entendimento pelo paciente do tratamento, do que está } \\
\text { acontecendo e do que deve ser feito }\end{array}$ & 44 & & \\
\hline 15 & $\begin{array}{l}\text { Recursos materiais, dependência adequada e pessoal } \\
\text { especializado }\end{array}$ & 50 & 50 & 31 \\
\hline 05 & Estrutura hospitalar, atendimento médico, boa consulta & 51 & 10 & 11 \\
\hline 44 & $\begin{array}{l}\text { Condições físicas do local (estruturais) paciente ser atendido } \\
\text { pela especialidade médica }\end{array}$ & 51 & 31 & \\
\hline 28 & $\begin{array}{l}\text { Boas condições de trabalho, equipamentos satisfatórios, } \\
\text { capacidade técnica }\end{array}$ & 51 & 51 & 30 \\
\hline 01 & $\begin{array}{l}\text { Silêncio, consulta pelo menos de } 20 \text { minutos, apoio paramédica } \\
\text { adequada }\end{array}$ & 60 & 10 & 50 \\
\hline 49 & $\begin{array}{l}\text { Ambiente agradável, calmo, tempo, diálogo, o paciente precisa } \\
\text { de atenção }\end{array}$ & 60 & 26 & 80 \\
\hline 58 & $\begin{array}{l}\text { Ambiente silencioso, sala adequada e raio } \mathrm{X} \text { grande com } \\
\text { equipamentos }\end{array}$ & 60 & 51 & \\
\hline 65 & Local adequado, material adequado, pontualidade & 60 & 51 & 14 \\
\hline 52 & $\begin{array}{l}\text { Local com explicações, local ideal para aguardar, bom } \\
\text { atendimento de consultório e após }\end{array}$ & 60 & 60 & \\
\hline 80 & Local e tempo adequado, saber ouvir e falar & 60 & 80 & 40 \\
\hline 68 & Local adequado (silêncio, conforto), tempo para fazer bom & 60 & 80 & 70 \\
\hline
\end{tabular}




\begin{tabular}{|c|c|c|c|c|}
\hline & exame, histórico e resolver o problema & & & \\
\hline 24 & Lugar adequado, tempo, disponibilidade & 60 & 80 & 80 \\
\hline 37 & $\begin{array}{l}\text { Eficácia do sistema, atendimento de paramédicos eficiente, bom } \\
\text { relacionamento com o médico }\end{array}$ & 70 & 10 & 21 \\
\hline 56 & Eficiente, rápido, atender a necessidade dele & 70 & 80 & 10 \\
\hline 16 & Resolutividade e clima amistoso & 70 & 295 & \\
\hline 35 & Maior tempo de consulta & 80 & & \\
\hline 31 & Tempo, mais vezes (freqüência) & 80 & 14 & \\
\hline 81 & $\begin{array}{l}\text { Tempo, acesso rápido aos exames, retornos sempre com o } \\
\text { mesmo médico }\end{array}$ & 80 & 14 & \\
\hline 21 & Tempo, boa relação médico-paciente, recurso & 80 & 21 & 51 \\
\hline 42 & $\begin{array}{l}\text { Tempo para ouvir, dedicação, conhecimento técnico, } \\
\text { consideração pelo paciente }\end{array}$ & 80 & 25 & 31 \\
\hline 09 & $\begin{array}{l}\text { Tempo de consulta, interesse do paciente, organização da } \\
\text { instituição }\end{array}$ & 80 & 25 & 50 \\
\hline 63 & Sem pressa (é fundamental), ter capacidade de ouvir, paciência & 80 & 43 & 26 \\
\hline 50 & $\begin{array}{l}\text { Que o paciente tenha tempo para dizer o que sente, que o } \\
\text { médico ouça o que ele diz e que faça o melhor para o paciente }\end{array}$ & 80 & 43 & 31 \\
\hline 45 & $\begin{array}{l}\text { Tempo suficiente (isso é fundamental), condições adequadas, } \\
\text { instalações adequadas, maior conforto para o paciente, exames } \\
\text { subsidiários }\end{array}$ & 80 & 50 & 51 \\
\hline 40 & Tempo, estrutura, boa formação & 80 & 51 & 30 \\
\hline 61 & Tempo, local adequado & 80 & 60 & \\
\hline 20 & Tempo, lugar adequado, instrumentos de suporte & 80 & 60 & 51 \\
\hline 88 & Tempo, local adequado, disponibilidade & 80 & 60 & 80 \\
\hline 64 & Maior tempo de espera, maior tempo para ouvi-lo & 80 & 80 & \\
\hline 23 & $\begin{array}{l}\text { Bastante tempo, poucos doentes por dia, infra-estrutura } \\
\text { adequada }\end{array}$ & 80 & 80 & 51 \\
\hline 55 & Isso é besteira, não preciso responder & 90 & & \\
\hline 27 & Desambição, atenção ao paciente, ambiente descontraído & 295 & 20 & 60 \\
\hline
\end{tabular}

\section{Quadro no 10}

Atributos para um bom atendimento ao paciente, com a concentração de códigos

\begin{tabular}{|c|l|c|}
\hline \multicolumn{2}{|c|}{ Questão 22 - Cite 3 atributos para um bom atendimento ao paciente } \\
\hline $\begin{array}{c}\text { № do } \\
\text { Questionário }\end{array}$ & Códigos \\
\hline 05 & Atendimento médico & 10 \\
\hline 37 & Atendimento de paramédicos eficiente & 10 \\
\hline
\end{tabular}




\begin{tabular}{|c|c|c|}
\hline 51 & Melhor atendimento que o paciente tem & 10 \\
\hline 52 & Bom atendimento de consultório e após & 10 \\
\hline 56 & Atender a necessidade dele & 10 \\
\hline 59 & Atendimento dentro do horário & 10 \\
\hline 05 & Boa consulta & 11 \\
\hline 32 & Boa anamnesia & 11 \\
\hline 62 & Boa história & 11 \\
\hline 69 & Boa conversa (anamnese) & 11 \\
\hline 04 & Diagnosticar certo & 12 \\
\hline 12 & Saber diagnosticar & 12 \\
\hline 18 & Avaliação completa do paciente & 12 \\
\hline 26 & Bom diagnóstico & 12 \\
\hline 39 & Diagnóstico certo & 12 \\
\hline 47 & $\begin{array}{l}\text { Diagnosticar com precisão os seus problemas e buscar a melhor } \\
\text { terapêutica possível }\end{array}$ & 12 \\
\hline 57 & Bom diagnóstico & 12 \\
\hline 67 & Fazer bom diagnóstico & 12 \\
\hline 82 & Realização de anamnese completa & 12 \\
\hline 85 & Diagnóstico & 12 \\
\hline 03 & Bom exame clínico & 13 \\
\hline 07 & Fazer bom exame & 13 \\
\hline 08 & Bom exame clínico & 13 \\
\hline 12 & Saber examinar & 13 \\
\hline 17 & Exame adequado & 13 \\
\hline 19 & Examiná-lo bem & 13 \\
\hline 22 & Realização de exames & 13 \\
\hline 32 & Exame & 13 \\
\hline 36 & Bom exame físico & 13 \\
\hline 45 & Exames subsidiários & 13 \\
\hline 53 & Examinar bem o paciente & 13 \\
\hline 62 & Bom exame físico & 13 \\
\hline 70 & Ser examinado & 13 \\
\hline 79 & Examiná-lo com tranqüilidade & 13 \\
\hline 87 & Fazer bom exame físico & 13 \\
\hline 01 & Consulta pelo menos de 20 minutos & 14 \\
\hline 10 & Prontuário & 14 \\
\hline
\end{tabular}




\begin{tabular}{|c|c|c|}
\hline 12 & Saber fazer a devolução & 14 \\
\hline 17 & Satisfação do paciente & 14 \\
\hline 30 & Pontualidade & 14 \\
\hline 31 & Mais vezes (freqüência) & 14 \\
\hline 32 & Encaminhamento & 14 \\
\hline 36 & Adequar o medicamento às condições do paciente & 14 \\
\hline 45 & Maior conforto para o paciente & 14 \\
\hline 59 & Satisfação do paciente & 14 \\
\hline 65 & Pontualidade & 14 \\
\hline 67 & Boa conduta & 14 \\
\hline 67 & Conseguir realizar o que o paciente espera & 14 \\
\hline 70 & Retornos freqüentes & 14 \\
\hline 70 & Não esperar para ser atendido & 14 \\
\hline 71 & Tratamento & 14 \\
\hline 81 & Retornos sempre com o mesmo médico & 14 \\
\hline 85 & Conduta precisa & 14 \\
\hline 85 & Queixa seja bem identificada & 14 \\
\hline 03 & Atenção ao paciente & 20 \\
\hline 13 & Atenção do médico & 20 \\
\hline 14 & Atenção & 20 \\
\hline 26 & Atenção & 20 \\
\hline 27 & Atenção ao paciente & 20 \\
\hline 41 & Atenção & 20 \\
\hline 49 & O paciente precisa de atenção & 20 \\
\hline 72 & Atenção & 20 \\
\hline 76 & Atenção & 20 \\
\hline 78 & Atenção & 20 \\
\hline 86 & Atenção ao paciente & 20 \\
\hline 21 & Boa relação médico-paciente & 21 \\
\hline 26 & Boa relação médico-paciente & 21 \\
\hline 37 & Bom relacionamento com o médico & 21 \\
\hline 66 & Bom relacionamento & 21 \\
\hline 69 & Bom relacionamento médico/paciente & 21 \\
\hline 06 & Boa vontade & 22 \\
\hline 17 & Compreensão & 22 \\
\hline
\end{tabular}




\begin{tabular}{|c|c|c|}
\hline 42 & Consideração pelo paciente & 22 \\
\hline 59 & Compreensão dele & 22 \\
\hline 77 & Boa vontade & 22 \\
\hline 78 & Compreensão & 22 \\
\hline 86 & Boa vontade & 22 \\
\hline 02 & Boa educação & 23 \\
\hline 33 & Tratá-lo pelo nome & 23 \\
\hline 33 & Se apresentar ao paciente & 23 \\
\hline 38 & Educação & 23 \\
\hline 41 & Educação & 23 \\
\hline 11 & Confiança & 24 \\
\hline 17 & Confiança no médico & 24 \\
\hline 19 & Confiança & 24 \\
\hline 22 & Segurança & 24 \\
\hline 46 & Confiança & 24 \\
\hline 51 & Confiabilidade & 24 \\
\hline 71 & Confiança & 24 \\
\hline 09 & Interesse do paciente & 25 \\
\hline 42 & Dedicação & 25 \\
\hline 47 & $\begin{array}{l}\text { Interesse do médico pelo paciente ao atendê-lo com vista a } \\
\text { solucionar os problemas dele }\end{array}$ & 25 \\
\hline 72 & Dedicação & 25 \\
\hline 76 & Dedicação & 25 \\
\hline 77 & Dedicação & 25 \\
\hline 14 & Paciência & 26 \\
\hline 25 & Calma & 26 \\
\hline 38 & Paciência & 26 \\
\hline 49 & Calmo & 26 \\
\hline 60 & Paciência e disponibilidade para ouvir & 26 \\
\hline 63 & Paciência & 26 \\
\hline 74 & Paciência & 26 \\
\hline 30 & Respeito & 27 \\
\hline 39 & Respeito & 27 \\
\hline 69 & Respeito mútuo & 27 \\
\hline 11 & Simpatia & 28 \\
\hline 13 & Empatia & 28 \\
\hline
\end{tabular}




\begin{tabular}{|c|c|c|}
\hline 62 & Empatia & 28 \\
\hline 77 & Simpatia & 28 \\
\hline 46 & Transparência dos dois lados & 29 \\
\hline 47 & Honestidade do médico no exercício profissional & 29 \\
\hline 48 & Honestidade & 29 \\
\hline 60 & Sinceridade do paciente & 29 \\
\hline 25 & Competência & 30 \\
\hline 28 & Capacidade técnica & 30 \\
\hline 40 & Boa formação & 30 \\
\hline 47 & Competência técnica & 30 \\
\hline 48 & Competência & 30 \\
\hline 54 & Ser competente & 30 \\
\hline 74 & Competência & 30 \\
\hline 06 & Ter conhecimento técnico & 31 \\
\hline 11 & Conhecimento & 31 \\
\hline 15 & Pessoal especializado & 31 \\
\hline 42 & Conhecimento técnico & 31 \\
\hline 43 & Precisão & 31 \\
\hline 44 & Paciente ser atendido pela especialidade médica & 31 \\
\hline 50 & Que o médico faça o melhor para o paciente & 31 \\
\hline 66 & Conhecimento & 31 \\
\hline 72 & Conhecimento & 31 \\
\hline 83 & Conhecimento da especialidade & 31 \\
\hline 83 & Experiência & 31 \\
\hline 86 & Conhecimento & 31 \\
\hline 13 & Poder de comunicação do médico & 40 \\
\hline 39 & Comunicação & 40 \\
\hline 51 & Que o médico saiba informar o que ele tem & 40 \\
\hline 73 & Usar linguagem leiga & 40 \\
\hline 73 & Escrever legível & 40 \\
\hline 80 & Saber falar & 40 \\
\hline 87 & Falar no nível do paciente & 40 \\
\hline 290 & Troca de informações & 40 \\
\hline 08 & Conversar & 41 \\
\hline 36 & Diálogo & 41 \\
\hline
\end{tabular}




\begin{tabular}{|c|c|c|}
\hline 39 & Diálogo & 41 \\
\hline 49 & Diálogo & 41 \\
\hline 79 & Conversar & 41 \\
\hline 02 & Explicação correta & 42 \\
\hline 03 & Explicações inteligível & 42 \\
\hline 07 & Explicar direito & 42 \\
\hline 10 & O paciente precisa esclarecer o que ele tem & 42 \\
\hline 14 & Orientação & 42 \\
\hline 19 & Explicação & 42 \\
\hline 33 & Explicar e orientar adequadamente sobre a doença & 42 \\
\hline 57 & Boa orientação & 42 \\
\hline 71 & Esclarecer o diagnóstico & 42 \\
\hline 79 & Esclarecendo-o sobre o problema & 42 \\
\hline 82 & Esclarecimento dos aspectos para o doente & 42 \\
\hline 04 & Ouvir bem a queixa & 43 \\
\hline 06 & Saber ouvir & 43 \\
\hline 07 & Ouvir queixas clínicas & 43 \\
\hline 12 & Saber ouvir & 43 \\
\hline 19 & Ouvir bem & 43 \\
\hline 25 & Saber ouvir & 43 \\
\hline 29 & Ouvir bem & 43 \\
\hline 33 & Ouvir bem o que ele tem a dizer & 43 \\
\hline 34 & Ouvir o paciente & 43 \\
\hline 50 & Que o médico ouça o que ele diz & 43 \\
\hline 53 & Ouvir & 43 \\
\hline 57 & Escutar as queixas & 43 \\
\hline 63 & Ter capacidade de ouvir & 43 \\
\hline 73 & Escutar o que o doente tem a dizer & 43 \\
\hline 79 & Ouvi-lo com atenção & 43 \\
\hline 80 & Saber ouvir & 43 \\
\hline 34 & Responder as dúvidas & 44 \\
\hline 75 & Entendimento pelo paciente do tratamento & 44 \\
\hline \multirow[t]{2}{*}{75} & Entendimento do que está acontecendo e do que deve ser feito & 44 \\
\hline & Infra-estrutura & 50 \\
\hline 01 & Apoio paramédica adequada & 50 \\
\hline
\end{tabular}




\begin{tabular}{|c|c|c|}
\hline 09 & Organização da instituição & 50 \\
\hline 15 & Dependência adequada & 50 \\
\hline 18 & Condições de trabalho & 50 \\
\hline 28 & Boas condições de trabalho & 50 \\
\hline 30 & Desburocratizarão & 50 \\
\hline 45 & Condições adequadas & 50 \\
\hline 66 & Auxílio do HSPE & 50 \\
\hline 05 & Estrutura hospitalar & 51 \\
\hline 15 & Recursos materiais & 51 \\
\hline 20 & Instrumentos de suporte & 51 \\
\hline 21 & Recurso & 51 \\
\hline 23 & Infra-estrutura adequada & 51 \\
\hline 28 & Equipamentos satisfatórios & 51 \\
\hline 40 & Estrutura & 51 \\
\hline 44 & Condições físicas do local (estruturais) & 51 \\
\hline 45 & Instalações adequadas & 51 \\
\hline 58 & Sala adequada e raio $x$ grande com equipamentos & 51 \\
\hline \multirow[t]{2}{*}{65} & Material adequado & 51 \\
\hline & Local & 60 \\
\hline 01 & Silêncio & 60 \\
\hline 20 & Lugar adequado & 60 \\
\hline 24 & Lugar adequado & 60 \\
\hline 27 & Ambiente descontraído & 60 \\
\hline 49 & Ambiente agradável & 60 \\
\hline 52 & Local com explicações & 60 \\
\hline 52 & Local ideal para aguardar & 60 \\
\hline 58 & Ambiente silencioso & 60 \\
\hline 61 & Local adequado & 60 \\
\hline 65 & Local adequado & 60 \\
\hline 68 & Local adequado (silêncio, conforto) & 60 \\
\hline 80 & Local & 60 \\
\hline 84 & Ambiente & 60 \\
\hline \multirow[t]{2}{*}{88} & Local adequado & 60 \\
\hline & Resolubilidade & 70 \\
\hline 08 & Boa solução & 70 \\
\hline
\end{tabular}




\begin{tabular}{|c|c|c|}
\hline 16 & Resolubilidade & 70 \\
\hline 22 & Garantia de solução para o problema & 70 \\
\hline 37 & Eficácia do sistema & 70 \\
\hline 41 & Possível solução & 70 \\
\hline 43 & Eficiente & 70 \\
\hline 48 & Efetividade & 70 \\
\hline 56 & Eficiente & 70 \\
\hline 60 & Vontade de resolver o problema do paciente & 70 \\
\hline 68 & Resolver o problema & 70 \\
\hline 82 & Proposição de um tratamento mais eficaz & 70 \\
\hline & Tempo & 80 \\
\hline 02 & Tempo para ouvir o paciente & 80 \\
\hline 09 & Tempo de consulta & 80 \\
\hline 10 & Sem pressão no atendimento & 80 \\
\hline 20 & Tempo & 80 \\
\hline 21 & Tempo & 80 \\
\hline 23 & Bastante tempo & 80 \\
\hline 23 & Poucos doentes por dia & 80 \\
\hline 24 & Tempo & 80 \\
\hline 24 & Disponibilidade & 80 \\
\hline 31 & Tempo & 80 \\
\hline 35 & Maior tempo de consulta & 80 \\
\hline 40 & Tempo & 80 \\
\hline 42 & Tempo para ouvir & 80 \\
\hline 45 & Tempo suficiente (isso é fundamental) & 80 \\
\hline 49 & Tempo & 80 \\
\hline 50 & Que o paciente tenha tempo para dizer o que sente & 80 \\
\hline 56 & Rápido & 80 \\
\hline 61 & Tempo & 80 \\
\hline 63 & Sem pressa (é fundamental) & 80 \\
\hline 64 & Maior tempo para ouvi-lo & 80 \\
\hline 64 & Maior tempo de espera & 80 \\
\hline 68 & Tempo para fazer bom exame & 80 \\
\hline 80 & Tempo adequado & 80 \\
\hline 81 & Tempo & 80 \\
\hline
\end{tabular}




\begin{tabular}{|l|l|c|}
\hline 81 & Acesso rápido aos exames & 80 \\
\hline 84 & Tempo & 80 \\
\hline 88 & Tempo & 80 \\
\hline 88 & Disponibilidade & 80 \\
\hline & Não respondeu & 90 \\
\hline 55 & Não preciso responder & 90 \\
\hline 55 & Isso é besteira & 90 \\
\hline 16 & Clima amistoso & 295 \\
\hline 27 & Desambição & 295 \\
\hline 34 & Tirar a ansiedade & 295 \\
\hline 38 & Humildade & 295 \\
\hline 43 & Caloroso & 295 \\
\hline 57 & Saber seus medos & 295 \\
\hline 74 & Fazer cara de anjo & 295 \\
\hline 76 & Carinho & 295 \\
\hline 77 & Amor & 295 \\
\hline 78 & Delicadeza & 295 \\
\hline 83 & Bom senso & 295 \\
\hline
\end{tabular}

\section{A relevância das perguntas fechadas}

As perguntas fechadas requeriam respostas que fossem estritamente limitadas. O respondente teve uma escolha de alternativas das quais pode selecionar a resposta que correspondia à sua opinião particular sobre um determinado assunto.

\section{A codificação das questões fechadas}

Para questões fechadas a codificação pode ser estabelecida antes que o trabalho de campo fosse iniciado. Sua impressão no instrumento facilitou o trabalho, pois evitou que, antes que o instrumento passasse para a digitação, tivesse que passar por uma fase de registro de código. Exemplo:

Questionário dos médicos (questão 1) 
Sexo?

Masculino

Feminino

[ 2 ]

Foi feita a atribuição direta de códigos para cada opção assinalada, mantendose uma padronização, na medida do possível. Exemplo: Todo sim teve código 1 e todo não código 2.

\section{Codificação das questões semi-abertas:}

O tratamento dado foi o equivalente às duas categorias anteriores.

\section{Banco de dados}

a) Foi desenvolvido em Access versão 7.0 (digitação);

b) Foi processado através do software SPSS versão 7.2 e gerou tabelas de freqüências e de cruzamentos;

c) Foi feita uma consistência e verificação dos dados digitados;

d) Tabelas finais e gráficos foram feitos no Excel 7.0;

e) Texto de análise foi redigido em Word 97. 


\section{Capítulo IV}

Resultados e conclusões

"A medicina é a mais humana das ciências e a mais científica das humanidades"

Edmund Pellegrino

\section{Observações diárias de campo}

Considerou-se indispensável revelar essas observações do supervisor e dos pesquisadores de campo, já que elas complementam os dados e as informações obtidos através do instrumento da pesquisa, que foi o questionário.

Aqui estão alguns depoimentos espontâneos feitos pelos pacientes durante o estudo e que foram anotadas integralmente pelo pesquisador, no seu relatório diário. Eles são um retrato anônimo/coletivo do que acontece diariamente no Hospital do Servidor Público Estadual ${ }^{55}$.

\section{Entrevistando pacientes}

"Boa receptividade. Apenas um paciente da Fisiatria não quis responder o questionário, com a argumentação de que" "só tinha que falar bem de quem Ihe atendia".

A paciente da Clínica Médica disse que "estas perguntas são mais para as pessoas que se consultam sempre com o mesmo médico".

"A opinião sobre os médicos em geral é favorável. As únicas reservas são quanto à clareza de diagnósticos e prescrições e ao tempo que os médicos têm para as consultas. A demora no atendimento é citada em muitas respostas."

"Uma pessoa no ambulatório de Clínica Médica não quis responder, mais uma vez com a argumentação de que só tinha a falar bem do hospital."

\footnotetext{
${ }^{55}$ Os depoimentos dos pacientes e dos médicos estão grafados em negrito e itálico, os dos pesquisadores em itálico e os do supervisor em caracteres normais.
} 
Os entrevistados tiveram poucas queixas dos médicos. Entretanto, no que diz respeito ao atendimento dispensado pelos funcionários dos guichês, a marcação de consultas e a espera pelo atendimento, as reclamações foram comuns.

"Alguns pacientes perguntam se a pesquisa será capaz de realizar mudanças no cenário do atendimento médico. Uma queixa comum sobre alguns médicos é a pouca atenção que é dada aos pacientes durante a consulta. São comuns frases como "tem médico que nem olha para você" e "alguns doutores estão sempre malhumorados"'. Normalmente os entrevistados demoraram para citar os três fatores para haver uma boa comunicação com o paciente. Não foi o caso de uma professora de 31 anos, paciente da Fisiatria. Sem hesitar, ela respondeu: "Amor, Carinho e Respeito". E ainda confidenciou que, na opinião dela, “os pacientes com menos instrução são mal-educados com os médicos".

A Cardiologia e a Ginecologia, num hospital sempre cheio, foram os dois ambulatórios mais cheios, e que forneceram a melhor amostragem. Os de Fisiatria e Cirurgia Geral, dependendo do dia, podiam ter poucos pacientes. O ambulatório de Fisiatria é o mais pontual de todo o Hospital. O fato de os pacientes da Clínica Médica dividirem o mesmo espaço com os de Endocrinologia tornou a pesquisa na especialidade um pouco mais demorada.

Uma professora, paciente da Cardiologia, afirmou que "as pessoas mais humildes certamente vão ter respostas diferentes das minhas". Esta relação entre o nível de escolaridade (e até mesmo social) e as respostas dadas pelo entrevistado, em especial quando se pergunta sobre o nível de expectativa que o usuário tem do hospital, é um fator que pode ser levado em conta no momento da análise dos dados da pesquisa de campo.

As questões sobre os tempos de exame e diagnóstico dentro da consulta estão entre as que os entrevistados tiveram mais dificuldade para responder, principalmente porque a maioria dos pacientes não atenta para estes aspectos. Isto quando não surgem respostas do gênero: “O médico nem examina a gente, ele vai logo passando receita".

Foram entrevistadas pacientes, na Ginecologia, na Cardiologia, na Clínica Médica, na Cirurgia Geral e na Cirurgia Vascular, no período da manhã. O pouco 
tempo que os médicos têm para atender os pacientes foi mencionado com freqüência pelos entrevistados.

Um homem de 78 anos, paciente da Clínica Médica, relatou: “Eu passei num clínico aqui que me atendeu muito bem. Só que eu me chamo José Jacinto e ele colocou 'Orlando' na receita, apesar de ter meu cartão em mãos”.

Caminhando pelos corredores do hospital, foi sempre possível encontrar alguém discutindo com os funcionários dos guichês de marcação de consultas.

Uma dependente de funcionário, paciente da Cirurgia Vascular, disse que "não entende os diagnósticos, mas pede para um médico seu conhecido para Ihe explicar." Outra dependente, na Cirurgia Geral, falou que "só fica nervosa quando demora para ser atendida pelo médico".

Uma paciente da Cardiologia, viúva de funcionário, relatou que sua idade, 77 anos, apareceu como 75 numa ficha. Ela afirmou também que, "após três dias de espera para marcar consulta, Ihe indicaram o segundo andar como sendo o da Cardiologia (é o terceiro)". Ainda assim, disse que o "atendimento é bom, inclusive o das atendentes de guichê".

"Uma mulher de quarenta anos, paciente da Ginecologia, disse que encontrou num refeitório o ortopedista com quem tinha passado há mais de um ano. O médico a reconheceu e pediu para que marcasse consulta. Ela citou este caso como exemplo da consideração que os médicos, para ela, devem ter com seus pacientes. Em geral, são poucos os pacientes que citam nominalmente os médicos pelos quais passaram, quase sempre com elogios."

A maioria dos pacientes cita menos de três fatores na questão 29, que pedia para citar três fatores importantes para haver uma boa comunicação com o médico. Para muitos, a boa comunicação é decorrência de um único fator: que o médico fale na sua linguagem.

Durante a tarde, um paciente da Cardiologia afirmou que "costuma entender os diagnósticos, mas só quando a esposa o acompanha. Certa vez uma médica me receitou um remédio - Eupressin - mas nem o farmacêutico entendeu a letra. Tive de voltar para ela escrever uma nova receita", afirmou. 
"Um paciente disse que ouviu de um médico que trabalha nos Estados Unidos que os médicos naquele país não conversam entre si. Perguntei se ele achava que no Brasil acontecia a mesma coisa. A resposta foi negativa."

Uma mulher na Cirurgia Geral afirmou que teve de explicar três vezes ao médico que a "microcirurgia aqui", a qual se referia, não era por ser no Servidor, mas por ter sido feita na boca dela.

Um agente penitenciário, na Cirurgia Vascular, lembrou o fato de que a tolerância de atrasos dos pacientes é de 40 minutos. "Se você chega cinco minutos depois, mesmo que o médico não esteja, você perde a vaga", disse. Também afirmou que "os exames do Servidor não são aceitos pela Perícia Médica, na rua Maria Paula, no Centro. Por essa falta de sintonia, não consigo me aposentar por invalidez".

Disse um paciente da Cirurgia Geral: "Não faço plano de saúde particular porque quando você mais precisa, você não é atendido. É só para os muito ricos. Não passam de uma arapuca, prefiro ser atendido aqui".

Uma professora na Clínica Médica afirmou que pergunta tudo o que precisa saber ao médico, mesmo que ele não seja receptivo. "Afinal sempre descontam uma parte do salário para o IAMSPE". Na Gastrocirurgia, um aposentado falou algo parecido: "uma pessoa me disse que não viria aqui se não descontassem do salário".

"Na Ortopedia, enquanto eram feitas perguntas a uma mulher de 58 anos (que considerou o fato de um paciente se consultar várias vezes com o médico um sinal de confiança), um médico, ao chamar os pacientes, mostrou a uma funcionária que tinha duas fichas de uma mesma paciente com nomes diferentes. "Ela se chama Nádia e aqui está escrito Dinorah. É brincadeira???", afirmou."

Um paciente da Clínica Médica se recusou a responder, por se considerar "uma vítima do atendimento do hospital e ter críticas demais a respeito".

"Uma professora na Cirurgia Vascular afirmou: "Tive a sorte de nunca ter passado por um médico 'cavalo', mas no Pronto-Socorro fui muito mal atendida". Ao mesmo tempo, uma paciente de primeira consulta observou o crachá do 
pesquisador e, insatisfeita com a demora no atendimento, perguntou onde poderia fazer uma reclamação".

Na Gastrocirurgia, uma professora citou como exemplo da indiferença de alguns médicos o fato de que um especialista ignorou um problema hereditário que apresentava. E disse um dependente: "Saí do plano de saúde particular porque ele não cobria o que eu precisava e era caro".

"Na Cirurgia Vascular, uma paciente começou a responder o questionário. Chamada, quando saiu não quis mais responder. Ao mesmo tempo, diante da insistência com que uma funcionária chamava certa paciente, esta afirmou: "As pessoas chegam aqui às sete da manhã e, na hora que o médico chega, vão tomar leite".

Quanto ao que poderia ser feito para melhorar a comunicação entre médico e paciente, as respostas se dividiram em três grandes correntes. A primeira defendeu que o "diálogo já é bom e não precisa melhorar" (em geral, falam com a experiência pessoal em mente). A segunda argumentou que a melhora "depende das atitudes pessoais do médico e do paciente". O terceiro grupo condiciona o progresso a "mudanças na estrutura do hospital, inclusive o aumento da remuneração dos médicos".

Um funcionário da Secretaria da Agricultura, paciente da Gastrocirurgia, afirmou que percebeu melhoras no atendimento, mas acha que o IAMSPE deveria fazer mais convênios. "Para quem mora longe, como eu, que sou de Francisco Morato, fica difícil vir aqui".

O mesmo procedimento feito no estudo dos pacientes, onde o pesquisador anotava suas observações e os comentários do entrevistado, foi adotado com os médicos.

É impossível ignorar a insatisfação dos médicos quanto à política administrativa do Hospital, pois elas permearam seus relatos. As reclamações foram a respeito do tempo que eles têm para atender cada paciente; falta de apoio estrutural; ausência de comunicação entre eles e seus superiores para avaliar os problemas gerais que os atingem; e da massificação da medicina, que se refere à quantidade de Faculdades desqualificadas. 


\section{Entrevistando médicos}

No primeiro dia, as pesquisas foram realizadas nas Enfermarias dos Departamentos da Ginecologia e Obstetrícia e Cirurgia Geral e no Ambulatório da Clínica Médica. Nas demais Enfermarias e Ambulatórios não foi possível devido ao grande número de pacientes para cada médico. Foi possível observar a incompatibilidade entre os horários de trabalho previstos pelo Hospital e os cumpridos pelos médicos.

Entre as dificuldades, a abordagem tem merecido atenção. Relata uma pesquisadora: "Ao me identificar como pesquisadora alguns encerram a conversa com negativas sem se interessarem pelo tema."

Dos seis médicos procurados nos Ambulatórios, dois se recusaram a responder, um pediu para ser procurado outro dia, um afirmou que não teria tempo para responder (independente do dia, horário e local), e dois responderam (ambos estavam fora de horário de trabalho; um deles inclusive atendeu um representante de laboratório enquanto eram feitas as perguntas).

Nas observações sobre o questionário, houve o primeiro obstáculo nas questões onde se pediu para definir o tempo. Os entrevistados tiveram dificuldade de quantificar os tempos pedidos e afirmaram que "o diagnóstico é instantâneo, não leva tempo para fazer isso". Ao contrário disso, afirmam que "2 a 5 minutos para se explicar o uso de remédios é um tempo muito grande, se comparado ao tempo total de atendimento".

Na terceira parte do questionário, ao responderem a questão 23, que perguntava sobre o que poderia ser feito para melhorar a comunicação com o paciente consideraram respondida também a questão 25 , que questiona o que faltava ao médico para que o atendimento melhore, do ponto de vista da comunicação, ou seja, não fizeram distinção entre bom atendimento e boa comunicação.

As respostas das questões 26 e 27, sobre o entendimento e esclarecimento do diagnóstico, mostraram o descontentamento com a política administrativa do Hospital. Os entrevistados consideraram que as falhas de comunicação com o paciente se dão, em sua maioria, porque os médicos não trabalham em condições satisfatórias. As principais reclamações foram a respeito do tempo que eles têm para atender cada 
paciente; falta de apoio estrutural (inclusive esclarecimento ao paciente fora da sala de consulta); hierarquização excessiva que permite a desigualdade de salários/horas de trabalho entre médicos que dedicam tempo integral ao hospital e os que possuem consultório. Um dos médicos citou que não há comunicação entre eles e seus superiores para avaliar os problemas gerais que os atingem, assim alguns desses problemas são transferidos diretamente para o paciente (o exemplo aqui também foi o excesso de pacientes).

* № de pesquisas realizadas: 8 (2 Ginecologia e Obstetrícia, 1 Clínica Médica, 5 Cardiologia)

Todas as pesquisas foram realizadas na Enfermaria. Houve uma disponibilidade maior dos médicos da Cardiologia devido à visita geral que seria feita aos pacientes no período da manhã. Dos três médicos abordados nos Ambulatórios, nenhum estava disponível e somente um cogitou a possibilidade de realizá-la em outro dia.

Nas questões sobre tempo de consulta no ambulatório do hospital, foi comum que os médicos que possuem consultórios fizessem uma comparação entre o atendimento que é dado nos dois lugares. Complementaram dizendo que "o paciente do HSPE muitas vezes não colabora na consulta, porque já esperou muito tempo para ser atendido, não escolheu o médico e não terá muito tempo ali dentro".

"Os problemas administrativos continuam a ser citados, bem como a sobrecarga de trabalho, que seria uma conseqüência da má administração. Vale mencionar algumas frases como" "o médico aqui é simplesmente um operário de branco" (visto assim tanto pelos superiores como pelos pacientes); "eles pensam que nós somos máquinas de fazer consultas, o hospital quer produção e não qualidade, nós somos escravos da administração" (a respeito do aumento do número de pacientes nas consultas diárias).

$\mathrm{Na}$ questão 33, que fala da interferência da relação assimétrica, vale observar que somente duas pessoas responderam NÃO (uma delas com o sentido pretendido pela pergunta, a outra entendeu que, como médico, se há uma consciência de fragilidade do paciente, pode-se alterar a situação para que ela não influencie a comunicação durante o atendimento). 
A última questão (40) perguntava ao médico se o paciente esperava um atendimento que o HSPE não tem condições de oferecer. A grande maioria dos entrevistados respondeu que SIM, porque achou que o paciente tem "expectativas muito altas", "quer ser atendido na hora", "acha que seu problema é sempre pior do que o dos outros", entre outras coisas. Apesar disso, acreditaram que recurso material o Hospital tem. Os médicos que responderam NÃO afirmam "que o HSPE possui estrutura e recursos materiais para atender bem, desde que haja uma boa administração e conscientização da capacidade de atendimento". Concluiu-se então que o sentido é o mesmo nas duas respostas.

* № de pesquisas realizadas: 3 (1 Clínica Médica, 2 Cirurgia Geral).

Novamente as entrevistas foram feitas nas enfermarias em horário de visita. $O$ desencontro de informações (de horários e locais de trabalho dos médicos) dificultou a realização das entrevistas.

"A principal observação que pode ser feita no dia a respeito das pesquisas é que há uma grande diferença entre o atendimento dos médicos da Cirurgia Geral e os demais. O tempo de atendimento é muito relativo porque em alguns marca-se a cirurgia (rápido), em outros ocorre a realização da cirurgia (o tempo varia de acordo com a necessidade). Outro fator que ocorre é que o diagnóstico já vem pronto, portanto não há o procedimento normal de se ouvir as queixas do paciente, examiná-lo, explicar tratamento e uso de medicamentos. Geralmente isso já foi feito antes por outro médico.

Também pela situação de tensão na qual se encontra o paciente (durante a cirurgia), alguns médicos costumam falar sobre assuntos cotidianos para que o paciente se sinta mais à vontade".

* № de pesquisas realizadas: 1 (Cirurgia Geral)

"As dificuldades encontradas na semana passada para a realização das entrevistas se repetiram no dia de hoje. Foi elaborado um planejamento de trabalho, de acordo com a planilha fornecida pela Diretoria de Recursos Humanos do HSPE, no entanto não pode ser utilizado porque não era compatível com a prática. Como exemplo podemos citar um departamento que deveria contar com 13 médicos, no período da manhã das segundas-feiras, e apenas um se apresentou, duas horas mais tarde que o previsto." 
* № de pesquisas realizadas: 3 (Cardiologia)

Novamente todos os Ambulatórios foram visitados sem sucesso. A colaboração por parte dos médicos e funcionários desse setor foi sempre dificultada pelo número excessivo de pacientes desde cedo.

Houve também uma maior dificuldade para se conseguir falar com as médicas, visto que o número destas é muito reduzido.

* № de pesquisas realizadas: 12 (4 Cirurgia Geral, 2 Ginecologia e Obstetrícia, 2 Clínica Médica, 4 Cardiologia)

"As dificuldades de cada setor têm se mostrado um pouco mais específicas. Na Clínica Médica, por exemplo, há grande resistência por parte dos médicos em responder a pesquisa. Na Ginecologia e Obstetrícia o problema tem sido a localização dos médicos, pois a maioria atende nos ambulatórios e passam no máximo uma vez por semana nas enfermarias. Os médicos entrevistados nesse departamento, embora atendam também nos ambulatórios, cuidam somente de casos mais graves, como gravidez de alto risco, tumores e outras doenças especificas. Na Cirurgia Geral há a questão de horários divergentes e pouca pontualidade dos médicos, sempre atrasados. A Enfermaria da Cardiologia continua sendo o melhor departamento para a aplicação das pesquisas, no entanto, como há necessidade de se seguir a listagem, temos pouca opção"

"No dia de hoje foi possível incluir no relatório uma Carta Aberta ao público do IAMSPE $E^{56}$, na qual as reclamações e reivindicações são muito semelhantes às feitas pelos médicos durante a realização das pesquisas".

* № de pesquisas realizadas: 6 (4 Cirurgia Geral, 2 Clínica Médica)

Não foram realizadas observações.

№ de pesquisas realizadas: 5 (2 Cirurgia Geral, 3 Clínica Médica)

Após quase duas semanas de pesquisa, tendo um maior número de amostras, foi possível verificar que a maioria das médicas entrevistadas tem grande preocupação

\footnotetext{
${ }^{56}$ ASSOCIAÇÃO médica, dos médicos residentes e dos funcionários do IAMSPE, dos enfermeiros do HSPE. Carta Aberta à Comunidade do Iamspe.
} 
em ouvir o paciente. Esse "ouvir", segundo elas, "significa ir além das queixas físicas, é saber dos problemas cotidianos e das carências do doente". Uma das entrevistadas citou que "muitas vezes o paciente se sente tão feliz de 'desabafar' sua insatisfação com o atendimento do HSPE ou com sua vida pessoal, que só o fato de lhe dar um pouco de atenção faz com que ele 'esqueça' momentaneamente a doença.

"Outra entrevistada afirma que "a paciência, afeto e atenção deveriam ser requisitos básicos para que um médico pudesse atender pessoas que estão carentes em muitos sentidos". "No entanto, ela aponta também as dificuldades do médico de agir dessa forma, já que muitos estão sob tensão devido aos problemas de excesso de trabalho, burocratização e ineficácia da administração". "O ideal seria uma compreensão de ambas as partes, sobre as expectativas do paciente e as reais possibilidades do médico".

Sobre o questionário, houve uma nova observação: a questão 16, que pede o tempo utilizado para se dar o diagnóstico. De acordo com os médicos, "o diagnóstico vai sendo elaborado durante a anamnese e exame físico, portanto, dizê-lo é uma ação instantânea. Já, a explicação do diagnóstico é bastante variada, porque depende da necessidade do caso e do nível de entendimento do paciente. Assim, deve-se considerar a resposta como tempo médio de explicação do diagnóstico".

A questão 18, que pede o tempo esperado pelo paciente para ser atendido pelo médico, também foi contestada pelos entrevistados. A justificativa para não respondê-la foi sempre muito parecida; nos casos de "consultas do dia" (que não foram marcadas com antecedência) o doente precisou chegar muito cedo para garantir sua vaga sem saber o horário em que seria atendido. Se ele foi o primeiro da fila, não precisou esperar, mas se foi o último esperou até $3 \mathrm{~h}$. Nos casos de consulta marcada, o paciente também habitualmente chegou antes do previsto porque muitas vezes vêm de outra cidade.

Houve uma observação positiva sobre as questões 22 e 25. Ao responder a questão 22, sobre três atributos de um bom atendimento ao paciente, os entrevistados avaliavam como os problemas estruturais do HSPE influenciavam a relação médico/paciente; na questão 25 ele respondeu por uma possível falha médica (pessoal ou coletiva), ou seja, ele precisou pensar em assumir um erro. Alguns demoraram para 
responder, outros disseram que não há falha médica, mas existiram ainda os que respondem de imediato que faltava boa vontade e paciência.

* № de pesquisas realizadas: 5 (1 Ginecologia e Obstetrícia, 4 Cardiologia)

"Nas questões 23 e 25, que perguntam: o que poderia ser feito para melhorar a comunicação entre médico e paciente, e o que falta ao médico para que o atendimento melhore do ponto de vista da comunicação, tivemos hoje, outras observações além das já exaustivamente mencionadas": "falta de tempo e melhores condições de trabalho".

Um dos médicos entrevistados citou, referindo-se a questão 23, que "existe um desrespeito à imagem do médico, o paciente se tornou desconfiado, houve uma banalização da profissão". Para ele, "o HSPE precisaria realizar algum trabalho no sentido de esclarecer as pessoas sobre o que é e o que não é possível de ser feito pelo médico".

"No caso de um segundo médico entrevistado, notei um distanciamento entre as perguntas feitas e as respostas dadas. Todas as questões foram relativizadas, e as respostas não pareceram estar de acordo o que foi visto até agora".

* № de pesquisas realizadas: 4 (Fisiatria)

Início da pesquisa na Medicina Física. Não foi possível falar com a chefe de serviço devido aos problemas de horário. Apesar disso, os demais médicos desse departamento foram muito receptivos e atenciosos, o que facilitou a realização do número das entrevistas necessárias nesta clínica em um único período. A espera para a realização das quatro entrevistas não foi longa. Enquanto aguardava junto aos pacientes, pode-se comprovar que o tempo de espera deles também não é tão prolongado como em outros serviços.

$\mathrm{Na}$ Fisiatria, nota-se certa familiaridade entre médico e pacientes. Os médicos afirmaram que existe uma necessidade de conversar e dar atenção ao paciente, pois o tratamento clínico nessa especialidade é longo, abrange todo o cotidiano do doente, o que pede o envolvimento dos familiares ou pessoas próximas, já que muitas vezes o paciente é invalidado pela enfermidade. Assim, é essencial que se saiba o que se passa no seu dia-a-dia. “Alguns são meus pacientes há anos! Já sei tudo da vida 
deles, não tem como não perguntar sobre a família, os filhos, o cachorro...”. “É importante conquistar a confiança do paciente e garantir a participação da família porque muitos problemas não são $100 \%$ tratáveis, e se o paciente não vê resultados em pouco tempo, tende a ignorar nossas recomendações”.

A sensação que se teve após conversar com os médicos e observar o funcionamento da Fisiatria, é de que este é o melhor atendimento oferecido pelo Hospital. Mas, obviamente, essas observações devem ser confirmadas pelas entrevistas feitas aos pacientes.

* № de pesquisas realizadas: 6 (2 Gastrocirurgia, 2 Cirurgia Vascular, 2 Ortopedia)

Hoje foram iniciadas a pesquisa em outros três departamentos: Gastrocirurgia, Cirurgia Vascular e Ortopedia, por motivo da insuficiência de nomes nas demais clínicas. Como tem acontecido nos demais serviços, a maioria das entrevistas continuou a ser realizadas nas Enfermarias, no entanto isso não aconteceu com a Ortopedia, pois nessa Enfermaria permanecem os residentes, que cuidam geralmente de casos cirúrgicos ou traumatológicos. Portanto, as entrevistas desta clínica foram realizadas no ambulatório.

O primeiro problema apresentado, por um médico do Ambulatório da Ortopedia, foi a estrutura oferecida ao profissional do HSPE para o trabalho. Entre as reivindicações estava a necessidade de material e local adequado de trabalho. Nos Ambulatórios, por exemplo, houve sempre muito tumulto e barulho. Os funcionários entravam e saiam das salas de consulta interrompendo, muitas vezes, o atendimento. Para agravar a situação existiam alto-falantes transmitindo músicas em volume desagradável (isso pode ser comprovado durante a entrevista). De acordo com outros médicos, esse problema se repete em algumas Enfermarias, onde deveria haver silêncio absoluto.

* № de pesquisas realizadas: 4 (3 Ortopedia, 1 Ginecologia e Obstetrícia)

Os serviços trabalhados no dia de hoje foram Ortopedia e Ginecologia e Obstetrícia. Nos demais (Gastrocirurgia e Cirurgia Vascular) havia somente residentes. 
"Na Ginecologia, o médico entrevistado fez uma importante observação quanto à existência de diversos serviços dentro desse departamento: o Centro Obstétrico, o Ambulatório e a Enfermaria, sendo que no Ambulatório existem atendimentos diferenciados conforme a necessidade do caso. Um exemplo disso é o atendimento à gravidez de risco, pré-natal e câncer ginecológico. A diferenciação é importante porque, de acordo com o próprio médico, "esses serviços exigem uma relação mais "fechada" entre médico e paciente, são situações que envolvem uma carga emocional muito grande"."

"Nesses casos, vemos que a questão da assimetria da relação entre médico e paciente atua de uma forma bem específica: a mulher, além de estar sensivel, tende a desconfiar do que o médico diz, porque acha que seu problema é único e grave - algumas vezes realmente é - e que talvez não saiba resolver. Uma possível solução para esse problema seria colocar informação na mídia (como a prevenção do câncer de mama), já que muitas das mulheres que procuram ou são encaminhadas ao serviço são razoavelmente esclarecidas, têm nível escolar médio".

* № de pesquisas realizadas: 4 (2 Gastrocirurgia, 1 Cirurgia Vascular, 1 Ginecologia e Obstetrícia)

As dificuldades que têm sido apresentadas desde o início deste trabalho voltaram a se repetir. Apesar disso, foi possível falar em três Clínicas e detectar outro fator apontado pelos médicos como causa dos problemas de comunicação. O termo utilizado, "massificação da medicina", se refere à quantidade de Faculdades desqualificadas que estão "jogando" no mercado profissionais mal preparados". A hipótese citada pelos médicos seria de que essas faculdades podem até ensinar a técnica médica, no entanto não se preocupam com a "humanização do atendimento". O novo médico chega para trabalhar sem ter aprendido a "lidar com os problemas sociais que acompanham e fazem parte da doença do paciente". A situação é agravada quando o novato entra em um hospital com as características do IAMSPE e não em um "hospital particular bonitinho", pois muitos estudantes fazem medicina por status, e isso hoje em dia deixou de ser regra para ser exceção". 
* № de pesquisas realizadas: 6 (4 Ortopedia, 2 Cirurgia Vascular)

Novamente se falou dos aspectos sociais que "acompanham" o doente e da necessidade de conscientizar o profissional de medicina sobre a sua responsabilidade "não-técnica". A observação, que foi feita pelos médicos mais velhos (mais de 50 anos) e com mais tempo de casa, não se referiu necessariamente aos residentes que trabalham no IAMSPE, mas sim aos médicos mais jovens (entre 30 e 40 anos), contratados pelo Hospital. Alguns Residentes também falaram sobre isso, fazendo a mesma crítica.

"Sobre outros problemas que interferem na comunicação durante o atendimento, se falou em "questões sociais que independem dos médicos e do Hospital". Na verdade o que ocorre é que em algumas clínicas (como Cirurgia Vascular, Clínica Médica e Cardiologia) há um maior número de pacientes de baixa escolaridade, com maior dificuldade de entendimento. Para alguns médicos, esse é um grave problema que deve ser resolvido na esfera social. Talvez essa seja também uma justificativa para que os médicos se isentem da responsabilidade e da culpa por um atendimento inadequado".

* № de pesquisas realizadas: 7 (2 Gastrocirurgia, 1 Cirurgia Vascular, 1 Ortopedia, 3 Ginecologia e Obstetrícia)

"Nesses últimos dias de pesquisa, notamos uma prática importante, que embora não tivesse sido citada anteriormente, se repetiu algumas vezes durante esta semana. A observação é a seguinte": alguns médicos mencionaram "a existência de "falsos doentes". Esses "falsos doentes" seriam pessoas que marcam consulta numa tentativa de obter atestado médico ou licença de trabalho". De acordo com os médicos isso é muito comum, e traz problemas "desconfortáveis". O que geralmente acontece é que o paciente "cria" uma doença e quer que o médico confirme a existência dela. Mesmo sabendo que não existe nada de errado ali, alguns médicos até pedem exames para provar ao paciente que ele está são. No entanto, esses pacientes são insistentes, querem fazer seu próprio diagnóstico e são os responsáveis pela maioria das reclamações sobre o atendimento. Existe ainda o "paciente rebelde" que não aceita o tratamento e portanto não pode ser curado. Essa "rebeldia" tem diversas causas, que vão desde doenças muito graves que afetam o estado psicológico do paciente e influência de familiares até o não entendimento do 
tratamento. "Alguns pacientes não entendem nunca. Explico uma, duas, três vezes e aí ele finge que entendeu. Isso é um problema social que não dá para o Hospital resolver".

A ineficiência do pré-atendimento ambulatorial, ou seja, do serviço paramédico, foi o alvo geral de críticas. O atendimento paramédico consiste em orientar o paciente antes e depois das consultas. De acordo com os médicos, as falhas estão tanto no serviço burocrático (agendamento de consultas, exames e cirurgias) quanto nos procedimentos técnicos de auxílio ao médico. A triagem mal feita estaria adiando consultas de emergência. Se o paciente tivesse uma orientação sobre a especialidade médica correta que deveria procurar para o seu problema, antes de marcar a consulta, isso evitaria todo o processo de encaminhamento para outro setor, poupando médico, paciente e funcionário, além de liberar vagas para quem realmente precisa do serviço procurado.

Foi possível observar uma contradição no conceito dos médicos sobre o nível cultural dos pacientes. Enquanto muitos deles afirmam que os pacientes possuem um nível cultural (escolar) baixo (e portanto este seria o principal problema da possível ineficácia da comunicação entre médico e paciente), outros contestam dizendo que lidam com pacientes diferenciados de bom nível de entendimento, o que os tornariam também exigentes. A explicação encontrada para essa distinção foi que os serviços que atendem mais pessoas idosas (como Cirurgia Vascular e Cardiologia) e aqueles cujas especialidades são muito procuradas (como Clínica Médica e Ortopedia), provavelmente atendem pessoas com pouca escolaridade. Um exemplo são os vários encaminhamentos feitos pela Clínica Médica para outras especialidades (triagem inadequada). Uma pessoa esclarecida que identifique um problema em seu estômago, por exemplo, terá maior chance de procurar a Gastrocirurgia do que uma outra que não conheça a especialidade desta clínica.

Quanto à exigência, ela não seria exclusiva de uma parcela dos pacientes, e sim generalizada. Isso ocorreria porque o paciente teria consciência do seu direito, como servidor público ou dependente, de usufruir do HSPE. Ele não quer esperar, quer escolher o médico, ter atendimento personalizado, como em hospitais particulares. Se ele precisa esperar seis meses para fazer uma cirurgia, obviamente ele reclamará. No entanto, a diferença no atendimento que ele teve no Ambulatório e o que terá na 
Enfermaria poderá melhorar a imagem que ele tem do hospital. Isso foi dito por vários médicos de Ambulatórios e Enfermarias. "Lá embaixo (Ambulatório) o paciente está num Hospital Público, mas aqui (Enfermaria) é como num hospital particular".

Esses relatos voluntários dos médicos, do supervisor e dos entrevistadores e que, muitas vezes, foram um desabafo daqueles profissionais de saúde, mostram situações reais do cotidiano do Hospital do Servidor Público Estadual. É interessante entrever esse conjunto para então introduzir-se no que é a consulta nessa Instituição.

\section{Análise dos dados e das informações}

\section{A importância da consulta}

Devido à impossibilidade total de se verificar como ocorre a consulta, tanto nos ambulatórios quanto nas enfermarias, pois esse momento é sigiloso, (Artigo 11, do Código de Ética Médica) não foram analisados os relatos dos agentes que fazem parte da interação - o médico e o paciente -, mas sim como cada um deles interpreta e analisa essa comunicação, inerente à interação, qualificando-a de acordo com a sua história pessoal, nível intelectual e cultural, estado afetivo, status social e papéis psicossociais.

A relação médico-paciente estabelece-se, de início, no instante em que o paciente entra no consultório e passa a expor as suas queixas clínicas entremeadas de problemas pessoais. O médico ouve e compreende, orienta clinicamente e prescreve terapêuticas, e também apoia o paciente, visando maior êxito do tratamento. Tudo o que o paciente referiu, incluindo histórias paralelas à sua história clínica, deve ser para o médico uma manifestação psicoterápica: a liberação do material inconsciente. O que o paciente conta é de extrema importância (mesmo que não o pareça), pois, do contrário, ele não o teria referido naquele exíguo momento da consulta.

\section{A percepção dos médicos sobre a consulta e o paciente}

Constatou-se, no estudo, que a consulta dentro do ambulatório, obedece a um padrão para todas as especialidades pesquisadas, como pode ser percebido pelas 
respostas obtidas: $46,6 \%$ dos médicos têm o mesmo procedimento na consulta, da qual consta a anamnese, exames, diagnóstico e a prescrição. 38,6\% não diferem muito, alegando que fazem abordagem sobre as queixas, conversando, ouvindo e perguntando. 9,1\% dizem fazer um atendimento normal. Veja o quadro oㅜ $\mathbf{1 1}$.

O atendimento dentro do ambulatório

\begin{tabular}{|l|c|c|c|c|c|}
\hline \multicolumn{6}{|c|}{ Descreva como é feito o atendimento dentro do consultório. } \\
\hline & Códigos & Freqüências & Percentual & $\begin{array}{c}\text { Percentual } \\
\text { Válido }\end{array}$ & $\begin{array}{c}\text { Percentual } \\
\text { Acumulado }\end{array}$ \\
\hline $\begin{array}{l}\text { 4. Entrevista/histórico/anamnese, } \\
\text { exames, diagnóstico, prescrição }\end{array}$ & 4 & 41 & 46,6 & 46,6 & 46,6 \\
\hline 1. Abordagem sobre queixas & 1 & 19 & 21,6 & 21,6 & 68,2 \\
\hline 3. Conversa/ouvir/perguntar & 3 & 15 & 17 & 17 & 85,2 \\
\hline 2. Atendimento normal & 2 & 8 & 9,1 & 9,1 & 94,3 \\
\hline 6. Outros & 6 & 4 & 4,5 & 4,5 & 98,8 \\
\hline 5. Não respondeu & 5 & 1 & 1,1 & 1,1 & 100 \\
\hline & Total & 88 & 100 & 100 & \\
\hline \multicolumn{1}{|c|}{ Casos válidos } & 88 & Perdidos & 0 & & \\
\hline
\end{tabular}

Quanto ao número de pessoas atendidas pelo médico do HSPE, a média diária é de 12,8 pessoas. O CRM considera normal o atendimento de 16 pacientes em 4 horas de jornada médica na saúde pública, resultando em uma média de 15 minutos por paciente. A Consulta № 6.252/91, Ref.: Exercício Profissional, fl. 2, do qual consta o parecer do Conselho Regional de Medicina, ilustra essa posição. ${ }^{57}$

No que se refere ao tempo de consulta, o estudo mostrou que é variável e que $46,15 \%$ dos médicos gasta acima de 7 minutos para ouvir a queixa do paciente, enquanto 44,87\% utiliza de 3 a 6 minutos; o exame clínico demora de 3 a 6 minutos para $57,15 \%$ e para $33,77 \%$ acima de 7 minutos. O diagnóstico para $47,95 \%$ dos médicos leva de 1 a 4 minutos, e para $27,40 \%$ de 5 a 6 minutos. A explicação sobre como utilizar a medicação para $39,07 \%$ leva de 3 a 6 minutos, e para $34,38 \%$ de 1 a 2 minutos.

\footnotetext{
${ }^{57}$ CONSELHO FEDERAL DE MEDICINA. Consulta $n^{o}$ 6252/91. São Paulo, Conselho Federal de Medicina, 1991.
} 
Pode-se dizer que 7 minutos é um bom índice de tempo para a anamnese, já que é uma das fases mais importantes da consulta, e nota-se que a maioria dos médicos pesquisados está utilizando esse tempo; o exame clínico, que complementa a anamnese, é feito em 3 a 6 minutos, um tempo razoável, dependendo da doença, e esse índice é respeitado pela maioria dos médicos. Segundo os médicos, o diagnóstico é uma fase que demanda pouco tempo, pois é a verbalização, para o paciente, do nome da doença ou a suspeita da mesma. Em vista disso, o tempo de 1 a 4 minutos é bom. A utilização de 3 a 6 minutos para explicar os procedimentos sobre o tratamento é razoável, mas o mesmo não pode se dizer dos 34,38\% de médicos que gastam apenas de 1 a 2 minutos para fazê-lo.

Considerando que a maioria dos médicos do Hospital do Servidor Público Estadual trabalha 4 horas por dia (54,55\%) e que atendem uma média de 12,8 pacientes por dia, verifica-se que são 18 minutos e 45 segundos por paciente, estando essa Instituição dentro dos padrões previstos pelo CRM. O parecer do Conselho, feito à Consulta n 24.358/97, dá esclarecimentos quanto ao tempo de consulta ${ }^{58}$. Os folhetos são utilizados como material de apoio por $39,29 \%$ dos médicos e $46,43 \%$ fazem uso de outros materiais, $10,71 \%$ de fotos e apenas $3,57 \%$ de slides.

Quanto ao tempo de espera para o paciente ser atendido, a média é de 1 hora, 18 minutos e 9 segundos, na visão do médico.

Verificadas as condições temporais da consulta, buscou-se então o perfil do paciente do Hospital do Servidor Público Estadual na percepção do médico: a idade está na média em 46 anos e 5 meses, sendo $81,58 \%$ do sexo feminino e 18,42\% masculino; $49,28 \%$ com $2^{\circ}$ grau completo, $21,74 \%$ com primário, $11,59 \%$ com $1^{\circ}$ grau e 13,04\% consideraram variável. Apenas 4,35\% com nível universitário. Destes 41,03\% são professoras, 30,77\% são funcionários públicos, 12,82\% aposentados e 5,13\% são do lar.

Traçado o perfil do paciente, era necessário verificar a opinião do médico quanto à qualidade da comunicação, um dos principais fatores da interação entre ele e o paciente na consulta.

\footnotetext{
${ }^{58}$ JORNAL DO CREMESP. Ambulatório não é linha de montagem, julho/98, ano XVII, nº 130, p. 15.
} 
À solicitação para que citasse 3 atributos de uma boa comunicação, levou o profissional a imaginar um diálogo eficiente durante a consulta, ainda que isso não fosse pedido pelo entrevistador. As respostas obtidas, num total de 237 diferentes respostas, revelam em que contexto os médicos pensaram: a relação médico-paciente foi, juntamente com transmitir bem a informação, os primeiros e segundos atributos mais importantes com $19,41 \%$ cada um. O terceiro foi escutar o que o doente tem a dizer com 13,08\%, enquanto clareza aparece com $6,33 \%$ e concisão e objetividade com $5,06 \%$.

Os dois primeiros não são atributos inerentes à comunicação em si, mas ao processo de interação médico-paciente. Os atributos como clareza, concisão e objetividade, qualidades próprias da comunicação, aparecem com menor importância. Dentro da relação médico paciente, aparecem como fatores importantes: ambiente, atenção, boa vontade, bom diagnóstico, cordialidade e empatia. Transmitir bem a informação engloba clareza no que se fala, estar no nível do interlocutor, concisão, objetividade, didática, linguagem leiga, passar uma boa informação. Já, escutar o doente diz respeito a capacidade de ouvir, a disponibilidade e paciência para escutar o paciente.

A percepção do paciente feita pelo médico levou-o a imaginar novos papéis para si. Foram dadas 97 diferentes respostas. $O$ fato é que o médico se vê, em um primeiro momento, como alguém que quer ajudar o paciente, um orientador, um amigo (23,71\%); depois como uma solução para os seus problemas $(22,68 \%)$ e no último papel como médico, prestador de serviço técnico (13,40\%).

Coerente com sua afirmação anterior, onde se vê como um orientador, o médico verbalizou, também em 97 diferentes respostas, que primeiramente o paciente espera que ele solucione os seus problemas (44,33\%), depois espera a cura da doença $(17,53 \%)$ e depois quer atenção $(16,49 \%)$.

A comunicação aparece como a principal mediadora do bom atendimento, depois a própria relação médico-paciente e finalmente o atendimento em si. Nas suas 249 diferentes respostas, os médicos apontaram quais seriam os fatores preponderantes e imprescindíveis na relação médico-paciente: transparência dos dois lados, confiabilidade, honestidade, respeito mútuo, clima amistoso, educação e 
paciência, e no atendimento: anamnesia completa e consulta (exame e diagnóstico adequados, proposição de tratamento eficaz).

O profissional do Hospital do Servidor Público Estadual acha que essa comunicação com o paciente pode melhorar e, em 104 diferentes respostas, disse que será necessário mais tempo para atendê-lo 23,08\%, a redução do número de pacientes atendidos 18,27\% e melhoria da infra-estrutura 16,35\% (condições de trabalho no ambulatório/enfermaria, aparelhagem, paramédicos etc.).

Os médicos reconhecem que a cooperação deles seria necessária para melhorar o atendimento, do ponto de vista da comunicação, pois, se a deficiência existe, os fatores estariam ligados a eles mesmos (33,01\%). Depois viria a questão do tempo reduzido para atender o paciente $(27,18 \%)$, e no final da escala a infra-estrutura $(17,48 \%)$. A questão monetária aparece com uma expressão mínima de (6,80\%).

Além da busca da importância da comunicação na relação médico-paciente, era necessário checar ainda como o médico identificava uma comunicação clara. Para eles seria falar ou explicar em linguagem leiga, a do paciente (38,14\%), ou explicação com clareza (37,11\%), em terceiro lugar tem-se o fator compreensão e o mútuo entendimento do médico e paciente $(9,28 \%)$.

Mais uma vez o médico contextualizou a comunicação no momento da consulta, ainda que isso não fosse pedido pelo entrevistador.

O primeiro contato do médico com o paciente ocorre, na maioria dos casos, quando este está sob o efeito de uma crise aguda. Não é incomum, portanto, que o paciente esteja nervoso quando vai à consulta. Os médicos dizem que 45,88\% às vezes costumam ficar, $22,35 \%$ ficam nervosos e um percentual significativo de $31,76 \%$ não apresentam esse estado emocional.

Talvez por esse motivo, nas consultas, o paciente fale de assuntos que não se referem à doença especificamente. Segundo os médicos, 52,87\% dos pacientes costumam fazê-lo em todas as consultas; 6,90\% a partir da segunda consulta; 3,45\% na primeira; e igual percentual nunca o fazem. E qual é a posição do médico nessa situação? 54,65\% dos médicos afirmam que ouvem o paciente; $31,40 \%$ dizem que procuram entender o teor da conversa; apenas $2,33 \%$ dizem que procuram mudar de assunto. 


\section{A compreensão do paciente na percepção do médico}

Os médicos têm uma visão otimista do resultado das consultas, pois afirmam que $41,86 \%$ dos pacientes às vezes entendem o diagnóstico; 37,31\% costumam entendê-lo prontamente; e 20,93\% não o compreendem. Assim, 68,97\% pedem esclarecimentos sobre o mesmo $27,59 \%$ às vezes solicitam explicações; e 3,45\% não pedem informações.

Quanto ao tratamento, 47,67\% dos pacientes às vezes entendem o que precisam fazer quanto à medicação; 41,86\% sabem o que fazer; e 10,47\% não têm esse conhecimento. Desta maneira, 61,63\% pedem informações sobre os procedimentos; $26,74 \%$ às vezes pedem; e 11,63\% não o fazem.

Dos médicos entrevistados, 95,45\% acham que uma comunicação clara sobre os procedimentos ajudariam o paciente a um melhor desempenho; 2,27\% acham que não; e 2,27\% acham que às vezes ajudaria.

Os médicos detectam situações de crise, atribuídas a problemas de comunicação com o paciente com uma frequência de 2 vezes por semana $(21,84 \%)$; uma vez por semana (18,39\%); 16,09\% nunca têm problemas decorrentes de uma comunicação deficiente; $17,24 \%$ disseram que raramente isso acontece; e apenas $11,50 \%$ têm crises de 3 a 4 vezes por semana.

Quanto às condições de atendimento do Hospital do Servidor Público Estadual, 39,53\% dos médicos acham que os pacientes esperam um atendimento que a Instituição não tem condições de oferecer, enquanto $30,23 \%$ às vezes o fazem e igual percentual não o faz. Não foram questionadas quais seriam essas condições.

\section{A assimetria da relação médico-paciente}

Muito se tem discutido a respeito da assimetria nas relações de interação nos diversos grupos sociais, sejam elas na família, no trabalho, na escola e também na consulta médica. Nesta última, onde o médico tem o poder do conhecimento e da cura e o paciente está fragilizado pela doença, as conseqüências da assimetria podem ser mais perniciosas. 
Segundo Grunig ${ }^{59}$ pode-se dizer que é um modelo “Assimétrico de Duas Vias": desempenha uma função bastante parecida com o de assessoria de imprensa, (onde os praticantes disseminam a fé da organização envolvida, geralmente com informação incompleta, distorcida ou meia-verdade, através de uma comunicação monológica, de mão-única), embora seu propósito possa ser melhor descrito como uma persuasão científica. Seus adeptos utilizam a teoria da ciência social e das pesquisas sobre atitudes e comportamentos, a fim de persuadir os públicos a aceitarem o ponto de vista da organização e fazê-los se comportar de maneira que apóiem a organização.

Os médicos reconhecem a existência da assimetria. Para 14,8\% dos profissionais esse tipo de relação leva o paciente a uma situação de submissão, passividade e inferioridade; $13,6 \%$ acham que diminui a capacidade de entendimento $e$ atrapalha a comunicação; 11,4\% acreditam que o paciente fica assustado e inseguro; $6,8 \%$ crêem que o paciente fica ansioso pela solução do problema; e 5,7\% que o paciente tem medo de dizer que não entende. Só 3,4\% dos médicos afirmam que a assimetria é um fator positivo nessa relação.

Para Franklin ${ }^{60}$, a assimetria é devida a duas razões, entre outras: a primeira diz respeito à natural fragilidade do paciente. Não se deve entender essa fragilidade apenas sob o aspecto psicológico, variável conforme as diferenças de personalidade. Fragilidade significa aqui algo mais geral, que pode ser definido como a situação em que alguém se coloca sob o cuidado do outro. O que normalmente caracteriza a independência individual é poder cuidar de si mesmo. Espera-se do adulto maduro que ele possa fazê-lo e que seja fruto de uma decisão pessoal a entrega do cuidado de si a outro. Não é o que acontece na doença, quando a procura do médico já implica, de alguma forma, numa transferência de responsabilidade ao outro do ato de cuidar-se.

A outra razão é a autoridade proveniente do saber. Ao se colocar sob o cuidado do outro, o paciente o faz confiando em um saber diferenciado que o médico possui, e cujo exercício é vital para a recuperação da sua própria integridade física, psíquica e moral. Não há como fugir dessa situação. Mesmo que o paciente se mostre avesso, hesitante ou rebelde em relação ao médico, isto é, ao seu saber, nunca poderá relacionar-se em igualdade de condições, a não ser que ele mesmo seja médico e da

\footnotetext{
${ }^{59}$ GRUNIG, J. \& HUNT, T., op. cit.

${ }^{60}$ LEOPOLDO e SILVA, Franklin. Virtude de fazer o bem. São Paulo, Conselho Federal de Medicina, 1997, p. 8.
} 
mesma especialidade. Nas ocasiões em que o paciente procura ouvir outras opiniões médicas, para melhorar a aceitação do diagnóstico e dos procedimentos, a assimetria da relação persiste. O cotejo tem muito mais o propósito de avaliar o que pensa um número maior de profissionais, e nunca o que cada um diz, a partir do que cada um sabe.

A impossibilidade de poder cuidar-se sozinho, sentindo então a sua independência ameaçada, e de saber que depende do conhecimento médico para recuperar a saúde plena constituem dois fatores que colocam o paciente numa posição afastada do cuidado de si e do saber de si, isto é, numa impotência que configura a fragilidade.

Franklin considera que:

"Uma das questões fundamentais que se coloca sobre a assimetria concerne ao modo pelo qual o médico entende e vivência esta relação. É nesse ponto que os problemas éticos aparecem, por vezes de forma muito sutil. $A$ assimetria da relação leva o médico, muitas vezes, a não ver qualquer tipo de reciprocidade. Ele detém o saber e a responsabilidade sobre este saber. O paciente está sob os seus cuidados, e não pode ser considerado como alguém com quem o médico possa ou deva dividir as suas preocupações. $O$ médico assume, então, a fragilidade do paciente como condição inevitável e incontrolável, e isto pode ser levado a tal ponto que o paciente é anulado como pessoa. Nesta situação-limite, fica-se diante de um paradoxo da beneficência: o cuidado anula a pessoa que é o objeto do cuidado. Anula-o como indivíduo, como personalidade singular.

Talvez seja interessante assinalar aqui o limite entre a beneficência e o paternalismo, num entendimento e numa vivência eticamente inadequada de uma situação configurada pela fragilidade de um e pela autoridade derivada pelo saber do outro. E este limite se torna mais compreensível quando se nota que a sua transgressão provém de uma passagem, muitas vezes insensível e despercebida, do saber ao poder. É inegável que o saber médico confere àquele que o possui um poder, toda competência profissional que se traduz numa 
prática social inclui um poder. Este poder gera relações de subordinação, de perfis variáveis".

\section{O paciente e sua percepção da consulta e do médico}

A grande maioria dos 152 pacientes entrevistados havia sido atendida pela primeira vez nos serviços pesquisados $(97,37 \%)$ e os demais pelo menos pela segunda vez $(2,63 \%)$.

Procurou-se entrevistar o mesmo número de pacientes dos serviços elegidos, já que não houve disponibilidade do número total de pessoas atendidas, diariamente, em cada um deles. O quadro no 12 demonstra o número de entrevistados e o percentual correspondente.

\section{Quadro no 12}

Número de pacientes entrevistados por serviço

\begin{tabular}{|c|c|c|c|c|}
\hline \multicolumn{5}{|c|}{ O paciente estava no Serviço de: } \\
\hline & Serviços & Frequência & Percentual & Percentual Válido \\
\hline Válidos & Cardiologia & 20 & 13,16 & 13,16 \\
\hline & Cirurgia geral & 20 & 13,16 & 13,16 \\
\hline & Ortopedia & 20 & 13,16 & 13,16 \\
\hline & Fisiatria & 19 & 12,50 & 12,50 \\
\hline & Ginecologia & 19 & 12,50 & 12,50 \\
\hline & Gastrocirurgia & 19 & 12,50 & 12,50 \\
\hline & Cirurgia vascular & 18 & 11,84 & 11,84 \\
\hline & Clínica médica & 17 & 11,18 & 11,18 \\
\hline & Total & 152 & 100,00 & 100,00 \\
\hline
\end{tabular}

Foram entrevistados pela manhã $71,71 \%$, quando a demanda de marcação de consultas é maior e os demais a tarde $28,29 \%$. 
Quanto ao tempo de uso do serviços do Hospital, a maior frequência fica de 0 a 5 anos, com 47,37\%; depois de 6 a 10 anos (19,08\%); e de 11 a 15 anos tem-se um percentual de 6,58 .

\section{Quadro no 13}

Tempo de uso dos serviços do HSPE pelo paciente

\begin{tabular}{|c|c|c|c|c|}
\hline \multicolumn{5}{|c|}{ Há quanto tempo você usa o Hospital do Servidor Público? } \\
\hline \multirow{2}{*}{ Válidos } & 0 a 5 & Frequência & Percentual & Percentual Válido \\
\hline & 6 a 10 & 72 & 47,37 & 47,37 \\
\hline & 11 a 15 & 29 & 19,08 & 19,08 \\
\hline & 16 a 20 & 10 & 6,58 & 6,58 \\
\hline & 21 a 25 & 13 & 8,55 & 8,55 \\
\hline & 26 a 30 & 9 & 5,92 & 5,92 \\
\hline & 31 a 38 & 9 & 5,92 & 5,92 \\
\hline Total & Total & 10 & 6,58 & 6,58 \\
\hline
\end{tabular}

Dos 152 entrevistados, 87,50\% não tinham outro plano de saúde, apenas $12,50 \%$ tinham esse benefício.

A espera pelo atendimento médico está em torno de 31 a 60 minutos (32,89\%); 26,17\% dizem ter uma espera de 91 a 120 minutos; e para 16,78\% é de 0 a 30 minutos. 


\section{Quadro no 14}

Tempo de espera para o paciente ser atendido pelo médico

\begin{tabular}{|c|c|c|c|c|}
\hline \multicolumn{5}{|c|}{ Você costuma esperar em média quanto tempo para ser atendido pelo médico? } \\
\hline & & Frequência & Percentual & Percentual Válido \\
\hline Válidos & 0 a 30 & 25 & 16,45 & 16,78 \\
\hline & 31 a 60 & 49 & 32,24 & 32,89 \\
\hline & 61 a 90 & 14 & 9,21 & 9,40 \\
\hline & 91 a 120 & 39 & 25,66 & 26,17 \\
\hline & 121 a 180 & 16 & 10,53 & 10,74 \\
\hline & 181 a 240 & 4 & 2,63 & 2,69 \\
\hline & 241 a 300 & 1 & 0,66 & 0,67 \\
\hline & 301 a 360 & 1 & 0,66 & 0,67 \\
\hline & Total & 149 & 98,04 & 100,01 \\
\hline Perdidos & Perdidos pelo Sistema & 3 & 1,97 & \\
\hline & Total & 3 & 1,97 & \\
\hline Total & & 152 & 100,01 & \\
\hline
\end{tabular}

O paciente considera importante a anamnese, por isso demora mais de 7 minutos para relatar os seus sintomas (35,53\%); outros de 5 a 6 minutos $(34,21 \%)$; e $17,11 \%$ de 1 a 2 minutos, sendo que $13,16 \%$ o fazem de 3 a 4 minutos.

Para eles, $43,42 \%$ dos médicos demora mais de 7 minutos para examiná-los; outros (30,00\%) de 5 a 6 minutos; $15,33 \%$ de 3 a 4 minutos; e $10,67 \%$ de 1 a 2 minutos.

O diagnóstico é feito por 32,21\% dos médicos acima de 7 minutos; de 5 a 6 minutos para $30,20 \%$; de 1 a 2 minutos para $20,13 \%$; e de 3 a 4 minutos para $17,45 \%$ dos médicos.

A explicação sobre o tratamento demora de 5 a 6 minutos para $31,76 \%$ dos médicos; de 3 a 4 minutos para 23,65\%; para igual percentual acima de 7 minutos; e de 1 a 2 minutos para $20,95 \%$.

Pode-se considerar bom o tempo de 5 a 7 minutos para o paciente relatar os seus sintomas, já é ruim que o paciente utilize apenas de 1 a 2 minutos para fazê-lo, 
considerando que é praticamente impossível se fazer uma anamnese nesse tempo. De 3 a 4 minutos seria um tempo razoável.

Quanto ao exame clínico, a demora de 5 a 7 minutos para executá-lo é boa; de 3 a 4 minutos é razoável; de 1 a 2 minutos é ruim.

O diagnóstico é feito pela maioria dos médicos de 5 a 7 minutos, tempo considerado bom; alguns gastam apenas de 1 a 2 minutos, o que é ruim; o tempo de 3 a 4 minutos utilizado por alguns médicos é razoável. Muitos dos profissionais disseram que o diagnóstico é uma fase rápida da consulta, porque é apenas a verbalização do nome da doença ou a suspeita da mesma

O paciente tem uma visão positiva a respeito do seu entendimento durante a consulta. A maioria diz que entende o diagnóstico dado pelo médico (65,79\%); 24,34\% revela que às vezes compreende; e apenas 9,87\% diz que não. Quando não entende o diagnóstico; $71,71 \%$ dos pacientes pede para esclarecê-los; enquanto $14,47 \%$ não 0 faz e $13,82 \%$ só às vezes.

Dos pacientes entrevistados; 86,09\% entendem como devem fazer o tratamento; $7,95 \%$ revelaram que às vezes sim; apenas 5,96\% disseram que não. 63,82\% pedem esclarecimentos de como devem proceder; $26,32 \%$ não o fazem; e 9,87 às vezes o fazem.

A espera pelo atendimento médico está em torno de 31 a 60 minutos (32,89\%); 26,17\% dizem ter uma espera de 91 a 120 minutos; e 16,78\% de 0 a 30 minutos.

Apesar de a literatura médica abordar como possível a tensão do paciente na consulta, 70,39\% dos pacientes disseram não ficar nervosos quando vão falar com o médico; $15,13 \%$ às vezes ficam; e apenas $14,47 \%$ disseram que sempre ficam. 0 motivo, segundo eles, está ligado às atitudes dos próprios pacientes (50,00\%), 16,67\% alegaram que é porque os médicos não explicam direito, e igual percentual a outras causas como situações difíceis de se colocar para o médico, pela espera ou quando está preocupado com algum exame físico. 


\section{Quadro no 15}

O nervosimo do paciente

\begin{tabular}{|c|c|c|c|c|}
\hline \multicolumn{5}{|c|}{ Você fica nervoso quando vai falar com o médico? } \\
\hline & & Frequência & Percentual & Percentual Válido \\
\hline \multirow[t]{4}{*}{ Válidos } & Sim & 22 & 14,47 & 14,47 \\
\hline & Não & 107 & 70,39 & 70,39 \\
\hline & Às vezes & 23 & 15,13 & 15,13 \\
\hline & Total & 152 & 100,00 & 100,00 \\
\hline Total & & 152 & 100,00 & \\
\hline \multicolumn{5}{|l|}{ Por que? } \\
\hline \multirow[t]{7}{*}{ Válidos } & Sua própria atitude & 21 & 13,82 & 50,00 \\
\hline & Não explicam direito & 7 & 4,61 & 16,67 \\
\hline & Outras causas & 7 & 4,61 & 16,67 \\
\hline & Tratamento & 3 & 1,97 & 7,14 \\
\hline & Outros atributos & 2 & 1,32 & 4,76 \\
\hline & Não sabe & 2 & 1,32 & 4,76 \\
\hline & Total & 42 & 27,63 & 100,00 \\
\hline \multirow[t]{2}{*}{ Perdidos } & Perdidos pelo Sistema & 110 & 72,37 & \\
\hline & Total & 110 & 72,37 & \\
\hline Total & & 152 & 100,00 & \\
\hline \multicolumn{5}{|c|}{ Por que? (2) } \\
\hline \multirow[t]{4}{*}{ Válidos } & Motivados pelos pacientes & 21 & 13,82 & 50,00 \\
\hline & Outras causas & 12 & 7,89 & 28,57 \\
\hline & Motivado pelo médico & 9 & 5,92 & 21,43 \\
\hline & Total & 42 & 27,63 & 100,00 \\
\hline \multirow[t]{2}{*}{ Perdidos } & Perdidos pelo Sistema & 110 & 72,37 & \\
\hline & Total & 110 & 72,37 & \\
\hline Total & & 152 & 100,00 & \\
\hline
\end{tabular}

O usuário de serviços públicos de saúde, sofre os efeitos de um atendimento precário, como um grande número de pacientes para poucos médicos, o pouco tempo para a consulta e também o completo desconhecimento do seu interlocutor, já que nem 
sempre pode escolher o médico para a sua consulta. Talvez por isso ache inadequado iniciar conversas paralelas às suas queixas. 62,50\% disseram que nunca falam de assunto não-médico com o profissional que o atende; $10,53 \%$ o fazem em quase todas as consultas; e 23,03\% deram outras respostas: $6,58 \%$ às vezes/de vez em quando; 6,58\% depende do médico/depende muito do médico/ só quando o médico é conhecido/só com o clínico, há dez anos estou com eles/ quando eles são legais/faço, mas não aqui/outras.

Nestas situações, segundo os pacientes, a maioria dos médicos ouve o paciente falar do assunto $(57,14 \%) ; 25 \%$ tenta entender se o teor da conversa está ligado ao sintoma; 10,71\% tenta mudar de assunto; e 3,57\% ignora essa conversa.

O paciente percebe o seu interlocutor de uma maneira racional e lógica. 0 médico para o paciente é o profissional que cuida da saúde das pessoas (25\%); para igual percentual, uma pessoa muito importante para a saúde e também para os pacientes para 11,18\% um amigo. Para um pequeno percentual, é tido como: abaixo de Deus só o médico (7,89\%); um especialista que merece confiança (6,58\%); igual percentual como alguém importante, que cura as pessoas e que dá atenção; 4,61\% um orientador; 1,32\% um ser humano igual ao paciente.

É coerente também quando diz que o médico o vê como uma pessoa que precisa de ajuda, um ser humano (29,38\%); como um doente/paciente (12,5\%); para $11,88 \%$ depende do médico; para 8,75\% uma pessoa que precisa ser atendida; para $5,63 \%$ mais um paciente; para 3,75\% um amigo; para 1,88\% um estorvo; para igual percentual um cliente/consumidor.

Os pacientes estão satisfeitos com a comunicação entre o médico e o paciente, durante a consulta, pois $46,54 \%$ a consideram boa ou ótima; $12,58 \%$ importante; $8,81 \%$ disseram que depende da especialidade; apenas 6,92\% consideram difícil, devido ao pouco tempo; e 6,29\% ruim, muito ruim.

Quanto à comunicação clara sobre os procedimentos, $82,89 \%$ dos pacientes consideram que ajuda a melhorá-los e apenas $17,11 \%$ consideram que não. Os motivos, dados em 135 diferentes respostas, seriam por considerarem que um bom diálogo com uma boa explicação ajudariam a melhorar os procedimentos do paciente $(16,30 \%)$; o paciente vai saber o que tem que fazer, entenderá o que o médico diz 
$(15,56 \%)$; o paciente ganha confiança, fica mais seguro e se sente mais a vontade (14,82\%); o paciente bem orientado tem mais vontade para se tratar $(11,85 \%)$.

A qualidade da comunicação era um aspecto fundamental do estudo, bem como o paciente a avaliava. Havia necessidade de se comparar suas respostas com as do médico, perceber as diferenças ou semelhanças na sua doação de atributos e na importância dada a mesma no momento da consulta. Para essa questão os pacientes verbalizaram 342 diferentes respostas, apontando os três atributos que consideram mais importantes para uma boa comunicação entre o médico e o paciente: para $37,43 \%$ é a relação médico-paciente, depois a comunicação $(19,01 \%)$; e finalmente a atenção do médico 10,82\%.

No atributo relação médico-paciente, estão inseridos disposição, respeito, simpatia, sinceridade, e educação tanto do médico quanto do paciente, e também a dedicação, o interesse, a boa vontade, a afetividade, a confiança e a humanidade do médico. Da comunicação, fazem parte linguagem acessível, diálogo, clareza, entendimento, esclarecimento, e explicação mútua e médico ouvir com atenção. Da atenção, médico e paciente atenciosos.

O paciente parece ter baixas expectativas quanto ao momento da consulta, no que se refere à comunicação. 35,58\% consideram que a comunicação entre o médico e o paciente está boa e não precisa mudar. Enquanto 7,98\% acham que precisam de mais atenção do médico; 6,14\% acreditam que seria necessário mais diálogo e explicação do profissional e igual percentual de mais tempo de consulta.

A maioria dos pacientes entende que a relação assimétrica influencia na comunicação com o médico durante a consulta (73,68\%); 26,32\% consideram que não. É interessante ressaltar que o paciente vê que a diferença de conhecimento entre ele e o médico resulta em um ganho para si. Apesar dele considerar que é preciso haver entendimento mútuo e diálogo $(22,07 \%) ; 17,24 \%$ acham que o paciente fica mais a vontade, com mais confiança; $10,34 \%$ consideram que a boa relação ajuda na segurança e no tratamento; 9,66\% acham que o médico é um profissional que sabe o que fazer porque possui estudo.

Aqui também nota-se uma baixa expectativa dos pacientes, pois $50,40 \%$ consideram que o Hospital tem condições de oferecer o atendimento que dele se 
espera, enquanto $29,60 \%$ acham que às vezes não e $20,00 \%$ consideram que não tem condições.

\section{Comparando a percepção do médico com a do paciente}

Médicos e pacientes têm uma visão semelhante quanto às fases da consulta Ambos dizem que a anamnese demora mais de 7 minutos; o exame clínico na visão do paciente demora de 5 a 7 minutos, na do médico de 3 a 6 . Pode-se dizer, pela sua noção do tempo despendido, que o paciente está satisfeito. Quanto ao diagnóstico, à maioria dos médicos o faz de 1 a 4 minutos e para os pacientes demora de 5 a 7 . Como já foi dito anteriormente, o diagnóstico representa a verbalização do nome da doença ou de suspeita da mesma, portanto é possível fazê-lo no tempo mínimo de 1 minuto, ainda que não seja considerado um tempo ideal. O prognóstico leva, para os médicos, de 3 a 6 minutos e, para os pacientes, de 5 a 6 . Não existe uma diferença significativa do tempo gasto.

Ao se verificar o tempo da consulta, a intenção foi a de se constatar se elas são feitas ou não em um tempo condizente com os padrões do Conselho Regional de Medicina. Pode-se concluir que, tanto na visão do médico, quanto na do paciente, elas estão dentro daqueles padrões, ainda que considerados os tempos mínimos indicados por esses dois agentes.

Para o paciente, a média do tempo esperado é de 59 minutos e 28 segundos. $\mathrm{Na}$ visão do médico, a média é de 1 hora, 18 minutos e 9 segundos. Conclui-se que não existe uma diferença significativa do tempo esperado, na visão de ambos.

Médicos e pacientes têm opiniões diferentes sobre o entendimento do diagnóstico. Para os primeiros, a maioria dos doentes só às vezes o entende. Já, o paciente, na sua maioria, diz que o entende prontamente. Mas, 71,71\% dos pacientes disseram que pedem explicações quando não compreendem. Os médicos afirmaram que 68,97\% o fazem. Observa-se que o percentual de pacientes que pedem explicações é alto e talvez o diagnóstico só seja entendido depois de solicitada uma segunda explicação do mesmo. 
No entendimento do tratamento apresenta-se também uma discordância. Para os médicos menos da metade dos pacientes entende o tratamento. Já, para os pacientes, é quase maioria absoluta os que entendem. Entretanto, tanto para os médicos quanto para os pacientes, mais da metade desses últimos pedem informações sobre ele.

As questões sobre o entendimento, tanto do diagnóstico quanto do tratamento, tiveram a finalidade de se obter a confirmação de uma comunicação eficiente ou não entre o médico e o paciente.

Nas consultas onde surgem assuntos que não se referem à doença especificamente, temos uma visão diferenciada desses dois agentes. Apesar dos médicos afirmarem que a maioria dos pacientes o faz em todas as consultas, estes dizem, em sua maioria, que nunca o fazem. Cerca de um quarto dos entrevistados disseram que só de vez em quando.

A maioria dos médicos e dos pacientes afirma que quando isso acontece os médicos ouvem ao paciente. Há também coincidência no segundo índice de resposta: onde o médico tenta entender o teor da conversa.

A percepção desses dois agentes sobre a consulta, por vezes diferenciada, pode estar relacionada à intenção de se dar respostas consideradas corretas e também ao receio dos pacientes em parecerem educacionalmente despreparados em relação aos médicos.

Apesar dos médicos dizerem que é comum os pacientes estarem nervosos nas consultas, a grande maioria deles afirmou não estarem nesse estado emocional quando vão conversar com o médico. Entretanto, quando isso ocorre, não são os médicos os responsáveis. Os pacientes acham que o motivo está ligado as suas próprias atitudes. O médico interfere apenas quando não explica direito o diagnóstico e os procedimentos.

A percepção do médico de como o paciente 0 entende difere da realidade. $O$ médico se vê, em um primeiro momento, como alguém que quer ajudar o paciente, um orientador, um amigo, depois como uma solução para os seus problemas e só em um último papel como médico, prestador de serviço técnico. 
Para o paciente o médico é, em uma ordem decrescente, o profissional que cuida da saúde das pessoas, uma pessoa muito importante para a saúde e também para os pacientes, um amigo. Alguns disseram que abaixo de Deus só o médico. Outros, que é um especialista que merece confiança, que é alguém importante, que cura as pessoas e que dá atenção; um orientador; um ser humano igual ao paciente.

Em uma ordem de importância, o papel de orientador - que é aquele que indica o rumo - que é o de maior valor para o médico, aparece como de menor influência para o paciente, que o vê como o médico, já que é o profissional que cuida da saúde das pessoas. Não existe um ponto em comum na percepção de ambos quanto ao papel de amigo. O médico acha que é muito mais amigo do paciente do que na visão dos mesmos. Nenhum dos médicos se viu como uma divindade, entretanto um pequeno percentual dos pacientes o vê assim.

Na verdade, indicar o rumo tem coerência com a profissão médica, pois é esse profissional que vai dizer qual é o caminho para o restabelecimento da saúde. Entretanto considerar-se amigo do paciente não é um papel comum desempenhado por esses profissionais, principalmente na área da saúde pública, onde o paciente é quase um desconhecido e provavelmente não está ligado ao médico por laços de amizade e sim de competência técnica.

O paciente parece compreender e entender a relação médico-paciente, pois suas respostas são coerentes com o que seria o papel do médico, no senso comum. Ele acha que o médico o vê em primeiro lugar como uma pessoa que precisa de ajuda, um ser humano; depois como um doente/paciente; e, em seguida, como uma pessoa que precisa ser atendida; mais um paciente; um amigo; um estorvo; um cliente/consumidor. É também generosa sua percepção ao achar que o profissional tem consciência da sua fragilidade. Poucos se vêem como algo que atrapalha a vida do médico ou de uma maneira mercantilista.

O médico verbalizou que primeiramente o paciente espera que ele solucione os seus problemas, depois que cure a doença e finalmente que quer atenção. Essa solução dos problemas certamente deve estar ligada ao meio de superar uma dificuldade, que é a doença. A atenção, que o médico detecta como necessária, é um fator propulsionador das ações das pessoas com saúde, que se fortalecem com atos 
ou palavras que demonstrem consideração, amabilidade, urbanidade e cortesia do outro para com ela, portanto deve ser uma terapêutica para os doentes.

Para o médico, o bom relacionamento com o paciente dependeria em primeiro lugar da comunicação, depois da relação médico-paciente e do atendimento em si. A capacidade técnica aparece com baixo percentual. Nota-se que a comunicação é um fator de extrema importância nessa relação. Segundo Sanson e Maguire ${ }^{61}$ :

"Cerca de 50\% do tempo do médico, com pacientes, é gasto falando. Esta habilidade em comunicação tem um impacto significativo em obtenção de dados, adesão a regimes terapêuticos, satisfação do paciente, e respostas a procedimentos médicos e cirúrgicos potencialmente estressantes. A maneira de falar tem implicações, uma mesma pergunta com um mesmo significado pode ser expressa de maneiras diferentes. Um modo ameaçador: "O Sr. toma o seu remédio na hora certa como lhe foi dito, não?". Ou de uma maneira mais amistosa: "Muitas pessoas têm problemas para tomar remédio na hora certa ou se esquecem de tomá-los. O Sr. já teve estes problemas?". 62

Um pré-requisito para pacientes assimilarem os procedimentos terapêuticos é entendê-los e se lembrar das informações fornecidas. ${ }^{63,64}$

O médico do HSPE passa grande parte do seu dia do trabalho em contato constante com os pacientes, nas consultas, nos ambulatórios ou em visitas às enfermarias, talvez por isso ao ser solicitado que citasse 3 atributos de uma boa comunicação, imaginou um diálogo eficiente durante a consulta médica, ainda que isso não fosse pedido pelo entrevistador. As respostas obtidas, num total de 237 diferentes respostas, revelam esse contexto: a relação médico-paciente foi, juntamente com transmitir bem a informação, os primeiros e segundos atributos mais importantes com 19,41\% cada um. O terceiro foi escutar o que o doente tem a dizer, com 13,08\%, enquanto clareza aparece com $6,33 \%$ e concisão e objetividade com 5,06\%.

\footnotetext{
${ }^{61}$ SANSON-FISCHER, R.; MAGUIRE, P. Should skills in communicating with patients be taught in medical schools? Lancet, 1980, p. 523-6.

${ }^{62}$ BAILE, W.F.; GROSS, R.J. Hypertension, psycosomatic and behavioral aspects. Primary care, 1979, p. $267-82$.

${ }^{63}$ COLCHER, I.S.;BASS, J.W. Penicilin treatment of streptococal Pharingitis. JAMA, 1972, p. 657-9.

${ }^{64}$ SACKETT, D.L.;HAYNES, R.B. Randomized clinical trial of strategies for improving compliance in primary hipertensives. Lancet, 1975, p. 1205-07.
} 
Os dois primeiros não são atributos inerentes à comunicação em si, mas ao processo de interação médico-paciente. Os atributos como clareza, concisão e objetividade, que são qualidades próprias da comunicação, aparecem com menor importância. Dentro da relação médico-paciente, aparecem, como fatores importantes, ambiente, atenção, boa vontade, bom diagnóstico, cordialidade e empatia. Transmitir bem a informação engloba clareza no que se fala, estar no nível do interlocutor, concisão, objetividade, didática, linguagem leiga, passar uma boa informação. Já, escutar o doente diz respeito à capacidade de ouvir, que haja troca mútua de se ouvir, disponibilidade e paciência para escutar o paciente.

Coerentes com suas respostas sobre a boa comunicação, os médicos, em 342 respostas, consideraram que os três atributos mais importantes para uma comunicação entre o médico e o paciente deve ser: a relação médico-paciente (37,43\%); depois a comunicação 19,01\%; e finalmente a atenção do médico 10,82\%.

No atributo relação médico-paciente, estão inseridos disposição, respeito, simpatia, sinceridade, e educação, do médico e do paciente, e também a dedicação, o interesse, a boa vontade, a afetividade, a confiança e a humanidade do médico. Da comunicação, fazem parte linguagem acessível, diálogo, clareza, entendimento, esclarecimento, e explicação mútua e médico ouvir. Da atenção, é considerado inerente médico e paciente atenciosos.

O médico do Hospital do Servidor Público Estadual acredita que, para melhorar a comunicação com o paciente, seria necessário mais tempo para atendê-lo e também a redução do número de pacientes e a melhoria da infra-estrutura (condições de trabalho no ambulatório/enfermaria, aparelhagem, paramédicos etc.). Seria preciso que eles médicos cooperassem, pois supõe-se que, se a deficiência existe, os fatores estariam ligados a eles mesmos, depois viriam as questões do tempo reduzido para atender o paciente e a infra-estrutura.

Em contrapartida, a maioria dos pacientes considera boa ou ótima a comunicação que ocorre entre o médico e o paciente durante a consulta, que ela é importante, e alguns acham que depende da especialidade. Já, para alguns, ela é difícil, devido ao pouco tempo, e também ruim, muito ruim. 
Se não há um consenso quanto à qualidade da comunicação entre esses dois agentes, existe uma concordância na asserção que a qualidade piora/melhora na medida do menor/maior tempo gasto na consulta.

Uma comunicação clara para o médico seria falar ou explicar em linguagem leiga, igual a do paciente ou explicar com clareza, ou ainda compreensão e o mútuo entendimento do médico e paciente. Os pacientes consideram que uma comunicação clara sobre os procedimentos os ajuda a melhorá-lo; apenas um número reduzido considera que não.

As razões apresentadas são a de que: um bom diálogo com uma boa explicação ajudaria a melhorar os procedimentos do paciente; o doente saberia o que tem que fazer porque entenderia o médico. Com uma comunicação clara o paciente ganha confiança, fica mais seguro e se sente mais a vontade, que o doente bem orientado tem mais vontade para se tratar.

Foram abordados, ao longo do estudo, questões que interferem na comunicação: a linguagem, o tempo, a tensão, os meios, a personalidade dos interlocutores, nível intelectual e cultural dos agentes Essas intervenções podem trazer situações de crise para os médicos. No entanto, menos de um quarto deles detectam situações desse tipo com uma frequência de duas vezes por semana; um menor número, uma vez por semana ou raramente. Um baixo percentual nunca tem problemas decorrentes de uma comunicação deficiente; disseram que raramente isso acontece. Crises de três a quatro vezes por semana surgem apenas para um número reduzidíssimo.

Independente do índice, nota-se que a comunicação deficiente existe e traz conseqüências para o médico e para o paciente Esse fato não pode ser ignorado, já que se trata da integridade física e moral de seres humanos.

A maioria dos pacientes considera que o HSPE tem condições de oferecer 0 atendimento que dele se espera. Um percentual significativo de médicos discorda. Pode-se inferir que as expectativas dos pacientes são baixas quanto à qualidade e quantidade dos serviços públicos de saúde e os médicos têm maiores expectativas, talvez por terem conhecimento de novas terapêuticas e tecnologias de que o Hospital não dispõem. 


\section{Conclusões}

Ao se delimitar a área da pesquisa, fazendo o estudo de caso do Hospital do Servidor Público "Francisco Morato de Oliveira", houve a intenção primária de se oferecer à Instituição e à sociedade uma interpretação fiel de como médicos e pacientes avaliam a comunicação, dentro do ambulatório, compreendendo sua função mediadora da tensão existente entre as expectativas do paciente em relação ao atendimento idealizado e a realidade do serviço oferecido na área da saúde pública, tanto no que se refere ao médico quanto às condições oferecidas pela Instituição.

Este estudo impôs um grande aprendizado, motivado pelo convívio com os profissionais de saúde, no entendimento do seu contexto de trabalho, na observação acurada de suas rotinas laboriosas, na compreensão de toda uma terminologia médica e também foi perturbador e importante conhecer os caminhos, nem sempre fáceis, que percorrem os pacientes que buscam um serviço público de saúde em uma megalópole como é São Paulo.

É importante não se perder de vista que os dados e informações obtidos mostram uma realidade temporal que está permeada de significados, que foram interpretados pelo pesquisador de acordo com a sua percepção, ainda que se procurasse um distanciamento quanto ao objeto de estudo.

Neste trabalho se estudou a comunicação, segundo as duas perspectivas de Anzieu e Martin. A primeira foi a transferência de informação quantificável, onde o médico/emissor, conforme seu objetivo, encaminhou a mensagem para atingir o paciente/receptor. Nesse processo, podiam ocorrer problemas relativos ao emissor/médico, decorrentes da qualidade e pertinência de sua codificação; ao receptor/paciente, relativos à percepção correta dos sinais e à capacidade de decodificação; ao canal de comunicação, parasitas e desperdícios físicos que comprometem a quantidade e a qualidade de informação transmitida (ruídos); à retroalimentação, relativos à regulação quase automática do emissor mediante o controle de seus efeitos no receptor.

A segunda foram os aspectos psicossociológicos da comunicação, onde a comunicação foi vista como um contato entre o médico e o paciente, envolvidos numa mesma situação em que se debatem significações. Para tanto, foi importante 
considerar as personalidades: os comunicantes (médico e paciente), com sua história pessoal, sistema de motivações, estado afetivo, nível intelectual e cultural, marca de referência, status social e papéis psicossociais. Fatores que influem na emissão e recepção de mensagens. A comunicação proporcionando a ação do médico sobre o paciente e vice-versa, num contexto definido, caracterizando-se como um meio para transformar esse contexto.

Na consulta é que se inicia a interação e conseqüentemente a comunicação. A análise dos dados e informações do estudo levam à conclusão de que, com referência ao padrão de consulta, os médicos atendem às necessidades e expectativas do paciente e também estão nos limites de tempo e de número de consulta previstos pelo Conselho Regional de Medicina. Observa-se que as quatro fases da consulta são respeitadas pela maioria dos médicos.

Apesar de tanto médicos como pacientes terem levantado a questão do tempo assim como a do grande número de pacientes, os dados e as informações do estudo não apontam que haja interferências dessas duas variáveis no atendimento. Pode-se inferir que os médicos, pelo fato de terem mais de um emprego, estejam estressados não pelo ritmo de atendimento na Instituição, e sim pelo atendimento geral diário (Hospital mais outros empregos). Quanto aos pacientes, à demora temporal para ser atendida é considerada normal em uma instituição pública, e o médico respeita o tempo e as fases da consulta, como consta no próprio relato do paciente e também como mostrou o resultado do estudo: 16 pacientes em 4 horas de jornada médica, dando uma média de 15 minutos por paciente.

Levando-se em consideração que se interage, não com os indivíduos, mas com a imagem que se faz dele, conferindo identidade e significados aos mesmos, pode-se afirmar que o médico do HSPE pode não se perceber, mas suas ações o confirmam como um médico-humano. Trata-se de um profissional com as seguintes características:

a) têm grande experiência na profissão;

b) têm formação humanitária; 
c) são formados há pelos menos 20 anos, tempo em que os médicos davam mais atenção à anamnese e ao exame clínico, pois não contavam com os recursos terapêuticos e tecnológicos atuais; as consultas não eram cronometradas e médico e paciente tinham mais tempo para interagir, levando-os a uma relação até de amizade;

e) trabalham na Instituição há longo tempo, o que demonstra também uma relação afetiva com o local de trabalho.

Seguindo a perspectiva Grunig e $\mathrm{Hunt}^{65}$, na classificação de público, com referência à Instituição, pode-se dizer que o médico é um público consciente, porque reconhece os problemas existentes no HSPE e na relação médico-paciente e começa a se conscientizar deles e de suas causas; sendo também ativo porque tem se organizado para discutir os problemas e buscado propostas de solução para resolvêlos. Já, os pacientes são o público latente: aqueles que se sentem afetados por conseqüências da organização, porém não conseguem detectar claramente qual é o problema ou a causa. Essa classificação está sustentada pelos dados e informações do estudo e pelas observações de campo.

Quanto às condições de atendimento que o Hospital oferece, pode-se dizer, segundo o estudo, que o paciente está satisfeito com as mesmas, apresentando uma queixa ou outra sobre o atendimento paramédico. Talvez as questões como baixa escolaridade e nível social não lhe permitam ter a visão crítica necessária de como pode reivindicar e usufruir de melhores serviços públicos, assim o paciente não espera muito dessa instituição. Os médicos, ao contrário, estão insatisfeitos com as condições de trabalho e isso aparece com freqüência nos relatos espontâneos de campo e também quando pedem mais tempo para atender o paciente, menos pacientes agendados e melhoria na infra-estrutura. A questão financeira não aparece como uma preocupação maior.

Quanto ao processo comunicativo entre o médico e o paciente, verifica-se, pelo resultado do estudo, que deve partir do profissional a boa disposição para que este seja eficaz, embora o paciente tenha consciência de que precisa cooperar. O médico tem consciência de que a mensagem deve ser em linguagem leiga, acessível ao paciente, para que seja possível sua decodificação pelo paciente/receptor, de acordo

${ }^{65}$ GRUNIG, James E.; GRUNIG, Larissa A., op.cit. 
com o seu referencial, e também que os objetivos do médico/emissor sejam atingidos: maior índice de entendimento e obediência ao diagnóstico e tratamento, que beneficiará o paciente na cura ou o controle da doença. Havendo a cooperação recíproca, ocorre o feedback, que melhora a qualidade desse processo comunicativo, visto que médico e paciente têm seu comportamento condicionado um pelo outro. Há o entendimento mútuo, calcado na confiança, apesar da diversidade do universo simbólico e referencial do médico e do paciente.

Essa atitude evita o aparecimento de uma atmosfera hostil que pode causar erros de interpretação para o paciente e conseqüentemente ao tratamento terapêutico. Os interlocutores mantêm uma aproximação emocional e não se recusam a expor seus sentimentos. O médico vê a cura do paciente como um valor em si e não como um meio para outros valores, visto que a questão financeira aparece com pouca expressão.

Pode-se dizer, pelo resultado do estudo, que a interação comunicacional que ocorre entre o médico e o paciente é assimétrica e complementar (baseada na maximização da diferença), onde o comportamento de um completa o do outro. Apesar desse processo interativo ser complexo, se o ato comunicativo está em bom nível, e o resultado do estudo indica que sim, conclui-se que tanto o médico como o paciente compreendem que possuem diferentes interpretações da consulta e da doença. A assimetria e a complementaridade então não são fatores de impedimento de um contato produtivo, permitindo assim a comunicação mútua sobre a problemática do doente.

Os pacientes deixaram claro em seus relatos que a assimetria os beneficiava, os médicos têm opinião contrária, mas têm consciência do estado de submissão, passividade e inferioridade do paciente no momento da consulta e da conseqüente redução da sua capacidade de entendimento e comunicação. Certamente, procuram superar essas variáveis já que o ato comunicativo é considerado bom pelo paciente.

Quanto à percepção de si mesmo, o médico vê como seus papéis principais 0 de orientador e amigo, assim como o de oferecer solução aos problemas do paciente. O último papel é o de médico. No que se refere às expectativas do paciente quanto aos seus serviços, o profissional diz que o paciente espera primeiro que ele solucione seus problemas, depois a cura da doença e também quer atenção. Analisadas as 
repostas, deduz-se que orientar e solucionar problemas do doente estão ligados à cura ou controle da doença, portanto são solicitações técnicas inerentes à sua profissão, mas não estão desvinculadas do aspecto psicológico, caso contrário não teriam se referido às palavras: orientador, amigo e atenção.

Para o paciente, o médico é o profissional que cuida da saúde das pessoas, uma pessoa muito importante para a saúde e também para eles, é um amigo. A projeção que o paciente tem do médico é lógica e racional, pois esse é o papel principal do profissional. O médico tem consciência de um grau maior de amizade entre eles do que na percepção do paciente.

O paciente considera que o médico o percebe como uma pessoa que precisa de ajuda, um ser humano, um paciente, um amigo. Apenas um pequeno percentual adjetivaram negativamente essa percepção: um estorvo, um cliente/consumidor. Os resultados do estudo mostraram que os pacientes projetam nos médicos qualidades humanitárias por estarem satisfeitos com sua relação com eles.

De acordo com os resultados do estudo, a relação médico-paciente do HSPE é considerada boa tanto para o médico quanto para o paciente. Para este último, o profissional é muito importante para saúde deles; para o médico, o paciente é uma pessoa que precisa de ajuda. São posições afins e parecem ter como finalidade 0 bem estar do paciente. A comunicação aparece para o médico como o fator mais importante dessa relação, já que é com ela que vão se obter dados e informações, adesão a regimes terapêuticos e a satisfação de ambos agentes. A boa comunicação é para o médico: ambiente, atenção, boa vontade, bom diagnóstico, cordialidade, empatia, simpatia, respeito, sinceridade e educação dos dois agentes, a afetividade e a humanidade do médico - fatores que fazem parte da relação médicopaciente.

Os pacientes se mostram satisfeitos com a qualidade da comunicação e consideram-na importante. Para eles a comunicação clara é uma linguagem leiga, igual ao do paciente.

Pode-se concluir que o médico tem plena consciência dos fatores que interferem na comunicação e tem a disposição de buscar o entendimento e a confiança dos pacientes durante a consulta no Hospital do Servidor Público Estadual, já 
que os mesmos mostram-se contentes com o diálogo, têm compreensão das mensagens recebidas (diagnóstico e prescrição terapêutica) e sobretudo demonstraram que aquele profissional não é apenas um técnico e vêm utilizando sua competência humanitária na relação médico-paciente, compensando certamente as deficiências que por ventura surjam em um serviço público de saúde. Martin Burber define bem o requisito para um diálogo, diz ele ${ }^{66}$ :

"O principal requisito para o surgimento do diálogo genuíno é que cada um deve considerar seu parceiro tal como ele realmente é. Tome consciência dele, de suas diferenças em relação a mim, no modo definido e único que é peculiar a ele. E eu o aceito como vejo, para que possa me dirigir seriamente à sua própria pessoa. Talvez eu deva me opor a ele quanto ao assunto de nossa conversa. Mas eu aceito essa pessoa, em seu ser definido de onde se desenvolveu a convicção que carrega. Mesmo que eu deva mostrar, minuciosamente, o equívoco de sua posição, eu afirmo à pessoa que enfrento: Iuto com ele como parceiro, confirmo-o como criatura e criação. Eu confirmo a quem se me opõe como ele a mim. É verdade que agora depende do outro que o diálogo genuíno e o discurso mútuo se instalem entre nós. Mas se eu Ihe dar sua posição legítima como homem com o qual estou pronto a dialogar, então poderei confiar nele e supor que ele também estará apto para me considerar seu interlocutor."

Como conclusão final, infere-se que, apesar da saúde pública no Brasil atravessar há anos crises econômicas e sociais decorrentes da falta de vontade política dos governantes e dos administradores para resolvê-las, aumentando assim a desigualdade dos serviços médicos prestados e recebidos por quem pode pagar e aqueles que não podem, o Hospital do Servidor Público Estadual "Francisco Morato de Oliveira" abriga em seu quadro funcional médicos que, ainda que reclamem da situação insatisfatória de trabalho e talvez por sua formação humanitária, se preocupam com os resultados obtidos com as suas atividades e buscam superar

\footnotetext{
${ }^{66}$ BUBER, Martin. Elementos do inter-humano. In: MORTENSEN, C. David. Teoria da Comunicação. Wisconsin, Mosaico, 1980, p. 409.
} 
quaisquer deficiências materiais ou não para atender o paciente. Este último, sabedor das limitações dos serviços públicos de saúde, tanto pela própria experiência quanto pelas que são relatadas e mostradas pela mídia, mas sem recursos financeiros para outra opção, continua buscando, nos momentos mais crucias de sua vida, quando está doente, algo mais que a recuperação da saúde. Fatores como atenção, boa vontade, interesse, afetividade, respeito, confiança, sinceridade, cordialidade, empatia, educação, dedicação e humanidade fazem parte intrínseca dessa tentativa do paciente.

E é na junção desses dois agentes: o médico humanitário e o paciente conformado e esperançoso, que a comunicação vai ter a sua função maior. Não importa muito se o paciente compreende o que é comunicação clara, concisa e objetiva na relação médico-paciente, e sim se ela é fundamental para um diálogo eficiente. 0 que ele busca nessa relação terapêutica é que, ao transmitir as suas dores e aflições, o médico tenha a boa vontade e a paciência de ouvi-lo e compreendê-lo, e que sua resposta esteja no nível da sua compreensão, assim como todos os procedimentos necessários sejam apresentados de uma maneira didática. O paciente não espera e provavelmente não quer uma conversa com um técnico e sim com um ser humano com habilidade para ouvi-lo e ajudá-lo. 


\section{Anexo nํ 1}

\section{Código de Ética Médica}

Os médicos, no exercício da profissão, se utilizam dos conhecimentos técnicos e também dos seus valores morais. Como em outras profissões, esses profissionais têm um código de ética, dando-Ihes uma diretriz para os seus procedimentos.

Preâmbulo:

I - O presente Código contém as normas éticas que devem ser seguidas pelos médicos no exercício da profissão, independentemente da função ou cargo que ocupem.

II - As organizações de prestação de serviços médicos estão sujeitas às normas deste Código.

III - Para o exercício da Medicina, impõe-se a inscrição no Conselho Regional do respectivo Estado, Território ou Distrito Federal.

IV - A fim de garantir o acatamento e cabal execução deste Código, cabe ao médico comunicar ao Conselho Regional de Medicina, com discrição e fundamento, fatos que tenha conhecimento e que caracterizem possível infringência do presente Código e das Normas que regulam o exercício da Medicina.

V - A fiscalização do cumprimento das normas estabelecidas neste Código é atribuição dos Conselhos de Medicina, das Comissões de Ética, das autoridades da área da saúde e dos médicos em geral.

VI - Os infratores do presente Código sujeitar-se-ão às penas disciplinares previstas em lei.

\section{Capítulo I}

\section{Princípios Fundamentais}

Artigo 1 - A Medicina é uma profissão a serviço da saúde do ser humano e da coletividade e deve ser exercitada sem discriminação de qualquer natureza. 
Artigo 2 - O alvo de toda a atenção do médico é a saúde do ser humano, em benefício da qual deverá agir com o máximo de zelo e o melhor de sua capacidade profissional.

Artigo 3 - A fim de que possa exercer a Medicina com honra e dignidade, 0 médico deve ter boas condições de trabalho e ser remunerado de forma justa.

Artigo 4 - Ao médico cabe zelar e trabalhar pelo perfeito desempenho ético da Medicina e pelo prestígio e bom conceito da profissão.

Artigo 5 - O médico deve aprimorar continuamente seus conhecimentos e usar o melhor progresso científico em benefício do paciente.

Artigo 6 - O médico deve guardar absoluto respeito pela vida humana, atuando sempre em benefício do paciente. Jamais utilizará seus conhecimentos para gerar sofrimento físico ou moral, para o extermínio do ser humano ou para permitir e acobertar tentativa contra a sua dignidade e integridade.

Artigo 7 - O médico deve exercer a profissão com ampla autonomia, não sendo obrigado a prestar serviços profissionais que ele não deseje, salvo na ausência de outro médico, em casos de urgência, ou quando sua negativa possa trazer danos irreversíveis ao paciente.

Artigo 8 - O médico não pode, em qualquer circunstância ou sob qualquer pretexto, renunciar sua liberdade profissional, devendo evitar que quaisquer restrições ou imposições possam prejudicar a eficácia e correção de seu trabalho.

Artigo 9 - A medicina não pode, em qualquer circunstância ou de qualquer forma, ser exercida como comércio.

Artigo 10 - O trabalho do médico não pode ser explorado por terceiros com objetivo de lucro, finalidade política ou religiosa.

Artigo 11 - O médico deve manter sigilo quanto às informações confidenciais de que tiver conhecimento no desempenho de suas funções. O mesmo se aplica ao trabalho em empresas, exceto nos casos em que seu silêncio prejudique ou ponha em risco a saúde do trabalhador ou da comunidade. 
Artigo 12 - O médico deve buscar a melhor adequação do trabalho ao ser humano e a eliminação ou controle dos riscos inerentes ao trabalho.

Artigo 13 - O médico deve denunciar às autoridades competentes quaisquer formas de poluição ou deterioração do meio ambiente, prejudiciais à saúde e à vida.

Artigo 14 - O médico deve empenhar-se para melhorar as condições de saúde e os padrões dos serviços médicos e assumir sua parcela de responsabilidade em relação à saúde pública, educação sanitária e legislação referente à saúde.

Artigo 15 - Deve o médico ser solidário com os movimentos de defesa da dignidade profissional, seja por remuneração condigna, seja por condições de trabalho compatíveis com o exercício ético profissional da medicina e seu aprimoramento ético.

Artigo 16 - Nenhuma disposição estatuária ou regimental de hospital ou instituição pública ou privada poderá limitar a escolha, por parte do médico, dos meios a serem postos em prática para o estabelecimento do diagnóstico e para execução do tratamento, salvo quando em benefício do paciente.

Artigo 17 - O médico investido em função de direção tem o dever de assegurar as condições mínimas para o desempenho ético profissional da Medicina.

Artigo 18 - As relações do médico com os demais profissionais em exercício na área da saúde devem basear-se no respeito mútuo, na liberdade e independência profissional de cada um, buscando sempre o interesse e o bem-estar do paciente.

Artigo 19 - O médico deve ter, para com seus colegas, respeito, consideração, solidariedade, sem, todavia, eximir-se de denunciar atos que contrariem os postulados éticos à Comissão de Ética da instituição em que exerce seu trabalho profissional e, se necessário, ao Conselho Regional de Medicina.

\section{Capítulo II}

\section{Direitos do Médico}

É direito do médico: 
Artigo 20 - Exercer a medicina sem ser discriminado por questões de religião, raça, sexo, nacionalidade, cor, opção sexual, idade, condição social, opinião política ou de qualquer outra natureza.

Artigo 21 - Indicar o procedimento adequado ao paciente, observadas as práticas reconhecidamente aceitas e respeitando normas legais vigentes no país.

Artigo 22 - Apontar falhas nos regulamentos e normas das instituições em que trabalhe, quando as julgar indignas do exercício da profissão ou prejudiciais ao paciente, devendo dirigir-se, nesses casos, aos órgãos competentes e, obrigatoriamente, à Comissão de Ética e ao Conselho Regional de Medicina de sua jurisdição.

Artigo 23 - Recusar-se a exercer a profissão em instituição pública ou privada onde as condições de trabalho não sejam dignas ou possam prejudicar o paciente.

Artigo 24 - Suspender suas atividades, individual ou coletivamente, quando a instituição pública ou privada para a qual trabalhe não oferecer condições mínimas para o exercício profissional ou não o remunerar condignamente, ressalvadas as situações de urgência e emergência devendo comunicar imediatamente sua decisão ao Conselho Regional de Medicina.

Artigo 25 - Internar e assistir seus pacientes em hospitais privados com ou sem caráter filantrópico, ainda que não faça parte de seu corpo clínico, respeitadas as normas técnicas da instituição.

Artigo 26 - Requerer desagravo público ao Conselho Regional de Medicina quando atingido no exercício da profissão.

Artigo 27 - Dedicar ao paciente, quando trabalhar com relação de emprego, o tempo de experiência e capacidade profissional recomendarem para o desempenho de sua atividade, evitando que o acúmulo de encargos ou de consultas prejudique 0 paciente.

Artigo 28 - Recusar a realização de atos médicos que, embora permitidos por lei, sejam contrários ao ditames de sua consciência. 


\section{Capítulo III}

\section{Responsabilidade Profissional}

É vedado ao médico:

Artigo 29 - Praticar atos profissionais danosos ao paciente que possam ser caracterizados como imperícia, imprudência ou negligência.

Artigo 30 - Delegar a outros profissionais atos ou atribuições exclusivos da profissão médica.

Artigo 31 - Deixar de assumir responsabilidade sobre procedimento médico que indicou ou do qual participou, mesmo quando vários médicos tenham assistido ao paciente.

Artigo 32 - Isentar-se de responsabilidade de qualquer ato médico que tenha praticado ou indicado, ainda que este tenha sido solicitado ou consentido pelo paciente ou seu responsável legal.

Artigo 33 - Assumir responsabilidade por ato médico que não praticou ou do qual não participou efetivamente.

Artigo 34 - Atribuir seus insucessos a terceiros e a circunstâncias ocasionais, exceto nos casos em que isso possa ser devidamente comprovado.

Artigo 35 - Deixar de atender em setores de urgência e emergência, quando for de sua obrigação fazê-lo, colocando em risco a vida de pacientes, mesmo respaldado por decisão majoritária da categoria.

Artigo 36 - Afastar-se de suas atividades profissionais, mesmo temporariamente, sem deixar outro médico encarregado do atendimento de seus pacientes em estado grave.

Artigo 37 - Deixar de comparecer a plantão em horário preestabelecido ou abandoná-lo sem a presença de substituto, salvo por motivo de força maior.

Artigo 38 - Acumpliciar-se com os que exercem ilegalmente a Medicina, ou com profissionais ou instituições médicas que pratiquem atos ilícitos. 
Artigo 39 - Receitar ou atestar de forma secreta ou ilegível, assim como assinar em branco de receituários, laudos, atestados ou quaisquer outros documentos médicos.

Artigo 40 - Deixar de esclarecer o trabalhador sobre as condições de trabalho que ponham em risco sua saúde, devendo comunicar o fato aos responsáveis, às autoridades e ao Conselho Regional de Medicina.

Artigo 41 - Deixar de esclarecer o paciente sobre as determinações sociais, ambientais ou profissionais de sua doença.

Artigo 42 - Praticar ou indicar atos médicos desnecessários ou proibidos pela legislação do País.

Artigo 43 - Descumprir legislação específica nos casos de transplantes de órgão ou tecidos, esterilização, fecundação artificial e abortamento.

Artigo 44 - Deixar de colaborar com as autoridades sanitárias ou infringir a legislação pertinente.

Artigo 45 - Deixar de cumprir, sem justificativa, as normas emanadas dos Conselhos Federal e Regional de Medicina e de atender às suas requisições administrativas, intimações ou notificações, no prazo determinado.

\section{Capítulo IV}

\section{Direitos Humanos}

É vedado ao médico:

Artigo 46 - Efetuar qualquer procedimento médico sem o esclarecimento e o consentimento prévios do paciente ou de seu responsável legal, salvo a eminente perigo de vida.

Artigo 47 - Discriminar o ser humano de qualquer forma ou sob qualquer pretexto.

Artigo 48 - Exercer sua autoridade de maneira a limitar o direito do paciente de decidir livremente sobre a sua pessoa ou seu bem estar. 
Artigo 49 - Participar da prática de tortura ou outras formas de procedimento degradantes, desumanas ou cruéis, ser conveniente com tais práticas ou não as denunciar quando delas tiver conhecimento.

Artigo 50 - Fornecer meios, instrumentos, substâncias ou conhecimentos que facilitem a prática de tortura ou outras formas de procedimento degradantes, desumanas ou cruéis, em relação à pessoa.

Artigo 51 - Alimentar compulsoriamente qualquer pessoa em greve de fome que for considerada capaz, física e mentalmente, de fazer juízo perfeito das possíveis conseqüências de sua atitude. Em tais casos, deve o médico fazê-la ciente das prováveis complicações do jejum prolongado e, na hipótese de perigo de vida iminente, tratá-la.

Artigo 52 - Usar qualquer processo que possa alterar a personalidade ou a consciência da pessoa, com a finalidade de diminuir sua resistência física ou mental em investigação policial ou de qualquer outra natureza.

Artigo 53 - Desrespeitar o interesse e a integridade de paciente, ao exercer a profissão em qualquer instituição na qual o mesmo esteja recolhido independentemente da própria vontade.

Parágrafo único: Ocorrendo quaisquer atos lesivos à personalidade e à saúde física ou psíquica dos paciente a ele confiados, o médico está obrigado a denunciar o fato à autoridade competente e ao Conselho Regional de Medicina.

Artigo 54 - Fornecer meio, instrumento, substância, conhecimentos, ou participar, de qualquer maneira, na execução de pena de morte.

Artigo 55 - Usar da profissão para corromper os costumes, cometer ou favorecer crime.

\section{Capítulo V}

\section{Relação com Pacientes e Familiares}

É vedado ao médico: 
Artigo 56 - Desrespeitar o direito do paciente de decidir livremente sobre a execução de práticas diagnósticas ou terapêuticas, salvo em caso de iminente perigo de vida.

Artigo 57 - Deixar de utilizar todos os meios disponíveis de diagnóstico e tratamento a seu alcance em favor do paciente.

Artigo 58 - Deixar de atender paciente que procure seus cuidados profissionais em caso de urgência, quando não haja outro médico ou serviço médico em condições de fazê-lo.

Artigo 59 - Deixar de informar ao paciente o diagnóstico, o prognóstico, os riscos e objetivos do tratamento, salvo quando a comunicação direta ao mesmo possa provocar-lhe dano, devendo nesse caso, a comunicação ser feita ao seu responsável legal.

Artigo 60 - Exagerar a gravidade do diagnóstico ou prognóstico, complicar a terapêutica, ou exceder-se no número de visitas, consultas ou quaisquer outros procedimentos médicos.

Artigo 61 - Abandonar paciente sob seus cuidados.

Parágrafo 1으 - Ocorrendo fatos que, a seu critério, prejudiquem o bom relacionamento com o paciente ou pleno desempenho profissional, o médico tem o direito de renunciar ao atendimento, desde que comunique previamente ao paciente ou seu responsável legal, assegurando-se da continuidade dos cuidados e fornecendo todas as informações necessárias ao médico que lhe suceder.

Parágrafo $2^{\circ}$ - Salvo por causa justa, comunicada ao paciente ou a seus familiares, o médico não pode abandonar o paciente por ser portador de moléstia crônica ou incurável, mas deve continuar a assisti-lo, ainda que para mitigar o sofrimento físico ou psíquico.

Artigo 62 - Prescrever tratamento ou outros procedimentos sem exame direto do paciente, salvo em casos de urgência e impossibilidade comprovada de realizá-lo, devendo, nesse caso, fazê-lo imediatamente cessado o impedimento. 
Artigo 63 - Desrespeitar o pudor de qualquer pessoa sob seus cuidados profissionais.

Artigo 64 - Opor-se à realização de conferência médica solicitada pelo paciente ou seu responsável legal.

Artigo 65 - Aproveitar-se de situações decorrentes de relação médico-paciente para obter vantagem física, emocional, financeira ou política.

Artigo 66 - Utilizar, em qualquer caso, meios destinados a abreviar a vida do paciente, ainda que a pedido deste ou de seu responsável legal.

Artigo 67 - Desrespeitar o direito do paciente de decidir livremente sobre método contraceptivo ou conceptivo, devendo o médico sempre esclarecer sobre a indicação, a segurança, a reversibilidade e o risco de cada método.

Artigo 68 - Praticar fecundação artificial sem que os participantes estejam de inteiro acordo e devidamente esclarecidos sobre o procedimento.

Artigo 69 - Deixar de elaborar prontuário médico para cada paciente.

Artigo 70 - Negar ao paciente acesso a seu prontuário médico, ficha clínica ou similar, bem como deixar de dar explicações necessárias à sua compreensão, salvo quando ocasionar riscos para o paciente ou para terceiros.

Artigo 71 - Deixar de fornecer laudo médico ao paciente, quando do encaminhamento ou transferência para fins de continuidade do tratamento ou na alta, se solicitado.

\section{Capítulo VI}

\section{Doações e Transplante de Órgãos e Tecidos}

É vedado ao médico:

Artigo 72 - Participar do processo de diagnóstico da morte ou da decisão de suspensão dos meios artificiais do prolongamento da vida de possível doador, quando pertencentes à equipe de transplante. 
Artigo 73 - Deixar, em caso de transplante, de explicar ao doador ou seu responsável legal, e ao receptor, ou seu responsável legal, em termos compreensíveis, os riscos de exames, cirurgias ou outros procedimentos.

Artigo 74 - Retirar órgão de doador vivo quando interdito ou incapaz, mesmo com autorização de seu responsável legal.

Artigo 75 - Participar direta ou indiretamente da comercialização de órgãos ou tecidos humanos.

\section{Capítulo VII}

\section{Relações Entre Médicos}

É vedado ao médico:

Artigo 76 - Servir-se de sua posição hierárquica para impedir, por motivo econômico, político, ideológico, ou qualquer outro, que médico utilize as instalações e demais recursos da instituição sob sua direção, particularmente quando se trata da única existente na localidade.

Artigo 77 - Assumir emprego, cargo ou função, sucedendo a médico demitido ou afastado em represália a atitude de movimentos legítimos da categoria ou da aplicação deste Código.

Artigo 78 - Posicionar-se contrariamente a movimentos legítimos da categoria médica, com a finalidade de obter vantagens.

Artigo 79 - Acobertar erro ou conduta antiética de médico.

Artigo 80 - Praticar concorrência desleal com outro médico.

Artigo 81 - Alterar prescrição ou tratamento de paciente, determinado por outro médico, mesmo quando investido em função de chefia ou de auditoria, salvo em situação de indiscutível conveniência para o paciente, devendo comunicar imediatamente o fato ao médico responsável.

Artigo 82 - Deixar de encaminhar de volta ao médico assistente o paciente que Ihe foi enviado para procedimento especializado, devendo, na ocasião, fornecer-Ihe as 
devidas informações sobre o ocorrido no período em que se responsabilizou pelo paciente.

Artigo 83 - Deixar de fornecer a outro médico informações sobre o quadro clínico do paciente, desde que autorizado por este ou seu responsável legal.

Artigo 84 - Deixar de informar ao substituto o quadro clínico dos pacientes sob sua responsabilidade, ao ser substituído no final do turno de trabalho.

Artigo 85 - Utilizar-se de sua posição hierárquica para impedir que seus subordinados atuem dentro dos princípios éticos.

\section{Capítulo VIII}

\section{Remuneração Profissional}

É vedado ao médico:

Artigo 86 - Receber remuneração pela prestação de serviços profissionais a preços vis ou extorsivos, inclusive através de convênios.

Artigo 87 - Remunerar ou receber comissão ou vantagens por paciente encaminhado ou recebido, ou por serviços não efetivamente prestados.

Artigo 88 - Permitir a inclusão de nomes de profissionais que não participaram do ato médico, para efeito de cobrança de honorários.

Artigo 89 - Deixar de se conduzir com moderação na fixação de seus honorários, devendo considerar as limitações econômicas do paciente, as circunstâncias do atendimento e a prática local.

Artigo 90 - Deixar de ajustar previamente com o paciente o custo provável dos procedimentos, quando solicitado.

Artigo 91 - Firmar qualquer contrato de assistência médica que subordine os honorários ao resultado do tratamento ou à cura do paciente. 
Artigo 92 - Explorar o trabalho médico como proprietário, sócio ou dirigente de empresas ou instituições prestadoras de serviços médicos, bem como auferir lucro sobre o trabalho de outro médico, isoladamente ou em equipe.

Artigo 93 - Agenciar, aliciar ou desviar, por qualquer meio, para clínica particular ou instituições de qualquer natureza, paciente que tenha atendido em virtude de sua função em instituições públicas.

Artigo 94 - Utilizar-se de instituições públicas para execução de procedimentos médicos em pacientes de sua clínica privada, como forma de obter vantagens pessoais.

Artigo 95 - Cobrar honorários de paciente assistido em instituição que se destina à prestação de serviços públicos; ou receber remuneração de paciente como complemento de salário ou de honorários.

Artigo 96 - Reduzir, quando em função de direção ou chefia, a remuneração devida ao médico, utilizando-se de descontos a título de taxa de administração ou quaisquer outros artifícios.

Artigo 97 - Reter, a qualquer pretexto, remuneração de médicos e outros profissionais.

Artigo 98 - Exercer a profissão com intenção ou dependência de farmácia, laboratório farmacêutico, ótica ou qualquer organização destinada à fabricação, manipulação ou comercialização de produtos de prescrição médica de qualquer natureza, exceto quando se tratar de exercício da Medicina do Trabalho.

Artigo 99 - Exercer simultaneamente a Medicina e a Farmácia, bem como obter vantagem pela comercialização de medicamentos, órtoses ou próteses, cuja a compra decorra da influência direta em virtude da sua atividade profissional.

Artigo 100 - Deixar de apresentar, separadamente, seus honorários quando no atendimento ao paciente participarem outros profissionais.

Artigo 101 - Oferecer seus serviços profissionais como prêmio em concurso de qualquer natureza. 


\section{Capítulo IX}

\section{Segredo Médico}

É vedado ao médico:

Artigo 102 - Revelar fato de que tenha conhecimento em virtude do exercício de sua profissão, salvo por justa causa, dever legal ou autorização expressa do paciente.

Parágrafo único: Permanece essa proibição.

a) Mesmo que o fato seja de conhecimento público ou que o paciente tenha falecido.

b) Quando do depoimento como testemunha. Nessa hipótese o médico comparecerá perante a autoridade e declarará seu impedimento.

Artigo 103 - Revelar segredo profissional referente a paciente menor de idade, inclusive a seus pais ou responsáveis legais, desde que o menor tenha capacidade de avaliar seu problema e conduzir-se por seus próprios meios para solucioná-lo, salvo quando a não revelação possa acarretar danos ao paciente.

Artigo 104 - Fazer a referência a casos clínicos identificáveis, exibir pacientes ou seus retratos em anúncios profissionais ou na divulgação de assuntos médicos em programas de rádio, televisão ou cinema, e em artigos, entrevistas, ou reportagens em jornais, revistas ou outras publicações legais.

Artigo 105 - Revelar informações confidenciais obtidas quando do exame médico de trabalhadores, inclusive por exigência dos dirigentes de empresas ou instituições, salvo se o silêncio puser em risco a saúde dos empregados ou da comunidade.

Artigo 106 - Prestar às empresas seguradoras qualquer informação sobre as circunstâncias da morte de paciente seu, além daquelas contidas no próprio atestado de óbito, salvo por expressa autorização do responsável legal ou sucessor.

Artigo 107 - Deixar de orientar seus auxiliares e de zelar para que respeitem o segredo profissional a que estão obrigados por lei. 
Artigo 108 - Facilitar o manuseio e conhecimento de prontuários, papeletas e demais folhas de observações médicas sujeitas ao segredo profissional, por pessoas não obrigadas ao mesmo compromisso.

Artigo 109 - Deixar de guardar o segredo profissional na cobrança de honorários por meio judicial ou extrajudicial.

\section{Capítulo X}

\section{Atestado e Boletim Médico}

É vedado ao médico:

Artigo 110 - Fornecer atestado sem ter praticado 0 ato profissional que 0 justifique ou que não corresponda a verdade.

Artigo 111 - Utilizar-se do ato de atestar como forma de angariar clientela.

Artigo 112 - Deixar de atestar atos executados no exercício profissional, quando solicitado pelo paciente ou seu responsável legal.

Parágrafo único: $O$ atestado médico é parte integrante do ato ou tratamento médico, sendo o seu fornecimento direto inquestionável do paciente, não importando em qualquer majoração dos honorários.

Artigo 113 - Utilizar-se de formulários de instituições públicas para atestar fatos verificados em clínica privada.

Artigo 114 - Atestar óbito quando não o tenha verificado pessoalmente, ou quando não tenha prestado assistência ao paciente, salvo, no último caso, se o fizer como plantonista, médico substituto, ou em caso de necropsia e verificação médicolegal.

Artigo 115 - Deixar de atestar óbito de paciente ao qual vinha prestando, exceto quando houver indícios de morte violenta.

Artigo 116 - Expedir boletim médico falso ou tendencioso. 
Artigo 117 - Elaborar ou divulgar boletim médico que revele o diagnóstico, prognóstico ou terapêutica, sem expressa autorização do paciente ou de seu responsável legal.

\section{Capítulo XI}

\section{Perícia Médica}

É vedado ao médico:

Artigo 118 - Deixar de atuar com absoluta isenção quando designado para servir como perito ou auditor, assim como ultrapassar os limites das suas atribuições e competências.

Artigo 119 - Assinar laudos periciais ou de verificação médico-legal, quando não tenha realizado, ou participado pessoalmente do exame.

Artigo 120 - Ser perito de paciente seu, de pessoa de sua família ou de qualquer pessoa com a qual tenha relações capazes de influir em seu trabalho.

Artigo 121 - Intervir, quando em função de auditor ou perito, nos atos profissionais de outro médico, ou fazer qualquer apreciação em presença do examinado, reservando suas observações para o relatório.

\section{Capítulo XII}

\section{Pesquisa Médica}

É vedado ao médico:

Artigo 122 - Participar de qualquer tipo de experiência no ser humano com fins bélicos, políticos, raciais ou eugênicos.

Artigo 123 - Realizar pesquisa em ser humano, sem que este tenha dado consentimento por escrito, após devidamente esclarecido sobre a natureza e conseqüências da pesquisa. 
Parágrafo único: Caso o paciente não tenha condições de dar seu livre consentimento, a pesquisa somente poderá ser realizada, em seu próprio benefício, após expressa autorização de seu responsável legal.

Artigo 124 - Usar experimentalmente qualquer tipo de terapêutica ainda não liberada para uso no País, sem a devida autorização dos órgãos competentes e sem consentimento do paciente ou de seu responsável legal, devidamente informados da situação e das possíveis conseqüências.

Artigo 125 - Promover pesquisa médica na comunidade sem o conhecimento dessa coletividade e sem que o objetivo seja a proteção da saúde pública, respeitadas as características locais.

Artigo 126 - Obter vantagens pessoais, ter qualquer interesse comercial ou renunciar à sua independência profissional em relação a financiadores de pesquisa médica da qual participe.

Artigo 127 - Realizar pesquisa médica em ser humano sem submeter o protocolo a aprovação e acompanhamento de comissão isenta de qualquer dependência em relação ao pesquisador.

Artigo 128 - Realizar pesquisa médica em voluntários, sadios ou não, que tenham direta ou indiretamente dependência ou subordinação relativamente ao pesquisador.

Artigo 129 - Executar ou participar de pesquisa médica em que haja necessidade de suspender ou deixar de usar terapêutica consagrada e, com isso, prejudicar o paciente.

Artigo 130 - Realizar experiências com novos tratamentos clínicos ou cirúrgicos em pacientes com afecção incurável ou terminal sem que haja esperança razoável de utilidade para o mesmo, não the impondo sofrimentos adicionais.

\section{Capítulo XIII}

\section{Publicidade e Trabalhos Científicos}

É vedado ao médico: 
Artigo 131 - Permitir que sua participação na divulgação de assuntos médicos, em qualquer veículo de comunicação de massa, deixe de ter caráter exclusivamente de esclarecimento e educação da coletividade.

Artigo 132 - Divulgar informação sobre assunto médico de forma sensacionalista, promocional, ou de conteúdo inverídico.

Artigo 133 - Divulgar, fora do meio científico, processo de tratamento ou descoberta cujo valor ainda não esteja expressamente reconhecido por órgão competente.

Artigo 134 - Dar consulta, diagnóstico ou prescrição por intermédio de qualquer veículo de comunicação de massa.

Artigo 135 - Anunciar títulos científicos que não possa comprovar ou especialidade para a qual não esteja qualificado.

Artigo 136 - Participar de anúncios de empresas comerciais de qualquer natureza, valendo-se de sua profissão.

Artigo 137 - Publicar em seu nome trabalho científico do qual não tenha participado; atribuir-se autoria exclusiva de trabalho realizado por seus subordinados ou outros profissionais, mesmo quando executados sob sua orientação.

Artigo 138 - Utilizar-se, sem referência ao autor ou sem a sua autorização expressa, de dados, informações, ou opiniões ainda não publicados.

Artigo 139 - Apresentar como originais quaisquer idéias, descobertas ou ilustrações que na realidade não o sejam.

Artigo 140 - Falsear dados estatísticos ou deturpar sua interpretação científica.

\section{Capítulo XIV}

\section{Disposições Gerais}

Artigo 141 - O médico portador de doença incapacitante para o exercício da Medicina, apurada pelo Conselho Regional de Medicina em procedimento 
administrativo com perícia médica, terá seu registro suspenso enquanto perdurar sua incapacidade.

Artigo 142 - O médico está obrigado a acatar e respeitar os Acórdãos e Resoluções dos Conselhos Federal e Regionais de Medicina.

Artigo 143 - O Conselho Federal de Medicina, ouvidos os Conselhos Regionais de Medicina e a categoria médica, promoverá a revisão e a atualização do presente Código, quando necessárias.

Artigo 144 - As omissões deste Código serão sanadas pelo Conselho Federal de Medicina.

Artigo 145 - O presente Código entra em vigor na data de sua publicação e revoga o Código de Ética Médica (DOU 11/01/65), o Código Brasileiro de Deontologia Médica (Resolução CFM nº 1154 de 13/04/84) e demais disposições em contrário.

Publicado no D.O.U. de 26/01/88 - Págs. 1574/5/6/7. 


\section{Anexo no 2}

\section{Os direitos dos pacientes}

Promulgada pelo governador de São Paulo, Mário Covas, em 17 de março de 1999, a Lei número 10.241, que dispõe sobre os direitos dos usuários dos serviços e das ações de saúde no Estado, tramita novamente no Legislativo. A Assembléia ainda não tinha data definida para a votação que vai determinar a aprovação ou não dos vetos de Covas para o projeto do deputado Roberto Gouveia (PT), autor do texto que resultou na atual legislação. A nova lei estadual amplia os direitos dos pacientes, inclusive no que diz respeito a recusar tratamento, conforme previsto no Código de Ética Médica. "A legislação foi criada no sentido de incentivar a humanização do atendimento. $O$ paciente tem que ser encarado como o sujeito interessado, o maior participante do processo", defende Roberto Gouveia. Para o deputado, é importante que o médico divida com o paciente a responsabilidade do tratamento. "O profissional que tem uma boa formação não se sentirá lesado nem incomodado em dar informações, interagir com o paciente e encaminhar todas as explicações”, afirma.

\section{A Lei $\mathrm{n}$ ㅇ 10.241, na versão promulgada por Covas}

Dispõe sobre os direitos dos usuários dos serviços e das ações de saúde no Estado e dá outras providências.

\section{O governador do Estado de São Paulo:}

Faço saber que a Assembléia Legislativa decreta e eu promulgo a seguinte lei:

Artigo 1으 - A prestação dos serviços e ações de saúde aos usuários, de qualquer natureza ou condição, no âmbito do Estado de São Paulo, será universal e igualitária, nos termos do artigo 2으 da Lei complementar $\mathrm{n}$ 우 791, de 9 de março de 1995. 
Artigo 2o - São direitos dos usuários dos serviços de saúde no Estado de São Paulo:

I - ter um atendimento digno, atencioso e respeitoso;

II - ser identificado e tratado pelo seu nome ou sobrenome;

III - não ser identificado ou tratado por:

a) números;

b) códigos; ou

c) de modo genérico, desrespeitoso ou preconceituoso;

IV - ter resguardado o segredo sobre seus dados pessoais, através da manutenção do sigilo profissional, desde que não acarrete riscos a terceiros ou à saúde pública;

V - poder identificar a pessoas responsáveis direta e indiretamente por sua assistência, através de crachás visíveis, legíveis e que contenham:

a) nome completo;

b) função;

c) cargo; $\mathrm{e}$

d) nome da instituição;

VI - receber informações claras, objetivas e compreensíveis sobre:

a) hipóteses diagnósticas;

b) diagnósticos realizados;

c) exames solicitados;

d) ações terapêuticas;

e) riscos, benefícios e inconvenientes das medidas diagnósticas e terapêuticas propostas;

f) duração prevista do tratamento proposto;

g) no caso de procedimentos de diagnósticos e terapêuticos invasivos, a necessidade ou não de anestesia, o tipo de anestesia a ser aplicada, o instrumental a ser utilizado, as partes do corpo afetadas, os efeitos colaterais, os riscos e conseqüências indesejáveis e a duração esperada do procedimento; 
h) exames e condutas a que será submetido;

i) a finalidade dos materiais coletados para exame;

j) alternativas de diagnósticos e terapêuticas existentes, no serviço de atendimento ou em outros serviços; e

l) o que julgar necessário;

VII - consentir ou recusar, de forma livre, voluntária e esclarecida, com adequada informação, procedimentos diagnósticos ou terapêuticos a serem nele realizados;

VIII - acessar, a qualquer momento, o seu prontuário médico, nos termos do artigo 3으 da Lei Complementar ㄲo 791, de 9 de março de 1995.

IX - receber por escrito o diagnóstico e o tratamento indicado, com a identificação do nome do profissional e o seu número de registro no órgão de regulamentação e controle da profissão;

X - vetado;

$\mathbf{X I}$ - receber as receitas:

a) com o nome genérico das substâncias prescritas;

b) datilografadas ou em caligrafia legível;

c) sem a utilização de códigos ou abreviaturas;

d) com o nome profissional e seu número de registro no órgão de controle e regulamentação da profissão; e

e) com assinatura do profissional;

XII - conhecer a procedência do sangue e dos hemoderivados e poder verificar, antes de recebê-los, os carimbos que atestaram a origem, sorologias efetuadas e prazo de validade;

XIII - ter anotado em seu prontuário, principalmente se inconsciente durante o atendimento:

a) todas as medicações, com suas dosagens, utilizadas; e

b) registro da quantidade de sangue recebida e dos dados que permitam identificar a sua origem, sorologias efetuadas e prazo de validade;

XIV - ter assegurado, durante as consultas, internações, procedimentos diagnósticos e terapêuticos e na satisfação de suas necessidades fisiológicas: 

a) a sua integridade física;
b) a privacidade;
c) a individualidade;
d) o respeito aos seus valores éticos e culturais;
e) a confidencialidade de toda e qualquer informação pessoal; e
f) a segurança do procedimento;

XV - ser acompanhado, se assim o desejar, nas consultas e internações por pessoa por ele indicada;

XVI - ter a presença do pai nos exames pré-natais e nos momentos do parto.

XVII - vetado;

XVIII - receber do profissional adequado, presente no local, auxílio imediato e oportuno para a melhoria do conforto e bem estar;

XIX - ter um local digno e adequado para o atendimento;

XX - receber ou recusar assistência moral, psicológica, social ou religiosa;

XXI - ser prévia e expressamente informado quando o tratamento proposto for experimental ou fizer parte de pesquisa;

XXII - receber anestesia em todas as situações indicadas;

XXIII - recusar tratamentos dolorosos ou extraordinários para tentar prolongar a vida; e

XXIV - optar pelo local de morte.

\$10 - A criança, ao ser internada, terá em seu prontuário a relação das pessoas que poderão acompanhá-la integralmente durante o período de internação.

§20 - A internação psiquiátrica observará o disposto na Seção III do Capítulo IV do Título I da Segunda Parte da Lei Complementar no 791, de 9 de março de 1995.

Artigos $3 \stackrel{\underline{\underline{o}}}{4}$ 4으 e $5 \underline{\underline{o}}$ - vetados.

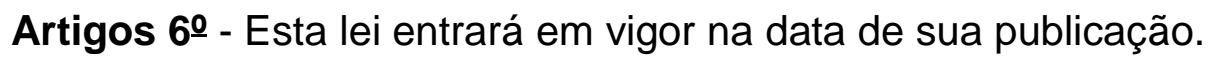

Palácio dos Bandeirantes, 17 de março de 1999 


\section{Anexo no 3}

\section{Questionário para os médicos}

\section{I - Identificação do respondente}

1. Idade [_] _ ] ] anos

2. Estado Civil

[ 1 ] solteiro [ 2 ] casado [ 3 ] divorciado [ 4 ] viúvo [5 ] outros:

identifique

3. Natural de

4. Reside na Zona Sul [1] Zona Norte [2]

Zona Leste [ 3 ] Zona Oeste [ 4 ]

Especifique Outros [ ]

5. Ano de conclusão da graduação

Título de especialista em Ano de conclusão 19

Mestrado Ano de conclusão 19

Doutorado Ano de conclusão 19

6. Tempo de Serviço do IAMSPE [__ _ _ ] anos. Obs. Se for menos que 1 ano coloque 0.

\section{II - Caracterização do Serviço}

7. Nome do Serviço

$\begin{array}{lll}1 \text { [ ] Cardiologia 2 [ ] Cirurgia Geral } & 3 \text { [ ] Clínica Médica } \\ 4[\text { ] Fisiatria } & \text { [ ] Ginecologia } & \text { 6[ ] Cirurgia Vascular } \\ 7[\text { ] Gastrocirurgia } & & \text { 8[ ] Ortopedia }\end{array}$

8. Quantos dias da semana trabalha no IAMSPE
[ ] 1 vez por semana [ ] 2 vezes por semana [ ] 3 vezes por semana
[ ] 7 vezes por semana

9. Horários em que trabalha

10. Descreva como é feito o atendimento dentro do consultório

11. Quantas pessoas em média atende por dia?

12. Quantos minutos você tem para atender cada paciente? [_] _ ] minutos

13. Quanto tempo em média você utiliza ouvindo o paciente?

a) 1 a 2 minutos [ ] b) 3 a 4 minutos [ ] c) 5 a 6 minutos [ ] d) 7 a 8 minutos [ ]

14. Quanto tempo em média você utiliza examinando o paciente?

a) 1 a 2 minutos [ ] b) 3 a 4 minutos [ ] c) 5 a 6 minutos [ ] d) 7 a 8 minutos [ ] 
15. Quanto tempo em média você utiliza dando o diagnóstico?
a) 1 a 2 minutos [ ] b) 3 a 4 minutos [ ] c) 5 a 6 minutos [ ] d) 7 a 8 minutos [ ]

16. Quanto tempo em média você utiliza para explicar ao paciente como deve tomar os remédios?
a) 1 a 2 minutos
] b) 3 a 4 minutos [ ]
c) 5 a 6 minutos [ ]
d) 7 a 8 minutos [ ]
17. O paciente costuma esperar em média quanto tempo para ser atendido pelo médico?
[_] ] minutos

\section{III - A Comunicação médico \& paciente}

18. Cite 3 atributos de uma boa comunicação.

19. O que você representa para o paciente?

20. O que o paciente espera de você?

21. Cite 3 atributos para um bom atendimento ao paciente.

22. O que poderia ser feito para melhorar a comunicação do médico com o paciente?

23. Você utiliza algum material de apoio?
[ ] slides
] folhetos explicativos
[ ] fotos
[ ] outros

24. O que falta ao médico para que o atendimento melhore, do ponto de vista da comunicação?

25. Os seus pacientes entendem prontamente qual é o diagnóstico que você deu? Sim [1] Não [2] Às vezes [3]

26. Os seus pacientes costumam pedir para você esclarecer o que eles têm, isto é, explicar o diagnóstico?

Sim [1] Não [2] Às vezes [3]

27. Os seus pacientes entendem prontamente qual é o tratamento que precisam fazer?

Sim [1] Não [2] Às vezes [3]

28. Os pacientes costumam pedir para você esclarecer como devem usar os medicamentos?

Sim [1] Não [2] Às vezes [3] 
29. Você considera que uma comunicação clara sobre os procedimentos que o paciente tem que fazer ajudaria a melhorar esses procedimentos?

Sim [1] Não [2] Às vezes [3]

30. O que você considera uma comunicação clara?

31. Com que freqüência você enfrenta situação de crise que possa ser atribuída a um problema de comunicação com o paciente?

[ ] Nunca [ ]1 vez por semana [ ] $2 \times$ por semana

[ ] $3 \times$ por semana[ ] $4 \times$ ou mais por semana

32. Para você a assimetria da relação médico \& paciente (onde o médico tem o poder do conhecimento e da cura e o paciente está fragilizado pela doença) influencia a comunicação durante $o$ atendimento?

Sim [ ] Não [ ]

Como?

\section{IV - A tensão do paciente}

33. Os pacientes costumam estar nervosos nas consultas?
[ 1 ] $\operatorname{Sim}$
[ 2 ] Não
[ 3 ] Às vezes

34. Com que freqüência o paciente fala de assunto não médico com você?

[ ] nunca [ ] na primeira consulta [ ] em quase todas as consultas

35. Como você reage nessa ocasião?

[ ] ouço [ ] procuro mudar de assunto [ ] procuro entender o teor da conversa está ligado ao sintoma [ ] ignoro [ ] outros.

Especifique

36. Você atende mais pessoas de que perfil?

Idade:

Sexo: $F[]$

Nível de escolaridade

Ocupação

37. Você acha que o paciente espera um atendimento que o HPSE não tem condições de oferecer?

Sim [11] Não [2] Às vezes [3] 


\section{Anexo no 4}

\section{Questionário para os pacientes}

\section{I - Identificação do respondente}

1. Sexo: Masculino [ 1 ] Feminino [ 2 ]

2. Idade [_] _ _ ] anos

3. Estado Civil

[ 1] solteiro [ 2] casado [ 3] divorciado [ 4] viúvo [ 5] outros.

Especifique

4. Natural de

5. Reside em São Paulo?

[ ] Sim. Em caso positivo, especificar:

Zona Sul [ 1] Zona Norte [ 2 ] Zona Leste [ 3 ] Zona Oeste [ 4]

Centro [ 5]

[ ] Não. Em que cidade?

6. Nível de escolaridade

[ ] Não-alfabetizado [ ] Semi-alfabetizado [ ] Primário [ ] Ginásio
[ ] Colegial [ ] Superior Incompleto [ ] Superior [ ] Outros

7. É funcionário do serviço ativo?

[ 1] Sim. Em caso positivo, especificar:

Órgão:

Função:

Tempo de serviço público: [ ] anos

[ 2] Não. Em caso negativo, especificar:

[, ] aposentado

Órgão:

Função:

[ ] Dependente de funcionário

\section{II - Atendimento no Hospital}

8. É a sua primeira consulta nesse serviço?
[1] Sim
[ 2 ] Não

9. O paciente estava no Serviço de:

1. Cardiologia [ ] 2. Cirurgia Geral [ ] 3. Clínica médica [ ] 4. Fisiatria [ ]

5. Ginecologia [ ] 6. Gastrocirurgia [ ] 7. Cirurgia vascular [ ] 8. Ortopedia [ ]

10. Hora da entrevista: [ ] ] minutos

11. Há quanto tempo você usa o Hospital do Servidor Público?

12. Você tem outro plano de saúde?

[ 2 ] Não [1] Sim.

Qual?

13. Você costuma esperar em média quanto tempo para ser atendido pelo médico? [_]__ minutos 
14. Quanto tempo em média você utiliza relatando seus sintomas?
a) 1 a 2 minutos
b) 3 a 4 minutos
c) 5 a 6 minutos
]d) 7 a 8 minutos [ ]

15. Quanto tempo em média o médico utiliza para examiná-lo?
a) 1 a 2 minutos
b) 3 a 4 minutos [ ]
c) 5 a 6 minutos
] d) 7 a 8 minutos [ ]

16. Quando tempo em média o médico utiliza explicando o que você tem?

a) 1 a 2 minutos [ ] b) 3 a 4 minutos [ ] c) 5 a 6 minutos [ ] d) 7 a 8 minutos [ ]

17. Quanto tempo em média o médico utiliza explicando o que você deve fazer?

a) 1 a 2 minutos [ ] b) 3 a 4 minutos [ ] c) 5 a 6 minutos [ ] d) 7 a 8 minutos [ ]

\section{III - A Relação médico \& paciente}

18. Você entende sempre qual é o diagnóstico que o médico deu?

Sim [1] Não [2] Às vezes [3]

19. Você costuma pedir para o médico esclarecer o que você tem, isto é, pede para explicar o diagnóstico?

Sim [1] Não [2] Às vezes [3]

20. Você entende sempre qual é o tratamento que precisa fazer?

Sim [1] Não [2] Às vezes [3]

21. Você costuma pedir para o médico esclarecer como deve usar os medicamentos?

Sim [1] Não [2] Às vezes [3]

22. Você fica nervoso quando vai falar com o médico?

Sim [1] Não [2] Às vezes [3]

Por quê?

23. Você costuma falar de assunto não médico com o doutor que 0 atende?

Freqüência: [ ] nunca [ ] na primeira consulta [ ] em quase todas as consultas [ ] outros.

Especifique:

24. Como ele reage nessa ocasião?

[ ] ouve [ ] ignora [ ] tenta mudar de assunto [ ] tenta entender se o teor da conversa está ligado ao sintoma [ ] outros.

Especifique

25. O que é o médico para você?

26. O que você acha que é para o médico?

27. O que você acha da comunicação entre o médico e o paciente durante o atendimento?

Explique 
28. Você considera que uma comunicação clara sobre os procedimentos que o paciente tem que fazer ajudaria a melhorar esses procedimentos?

[2] Não [1] Sim.

Por quê?

29. Cite 3 fatores que você considera importantes para haver uma boa comunicação entre o médico e o paciente:

30. O que poderia ser feito para melhorar a comunicação entre o médico e o paciente?

31. Para você, a relação entre o médico e o paciente (onde o médico tem o poder do conhecimento e da cura) influencia a comunicação durante 0 atendimento?

Sim [1] Não [2] Como?

32. Você acha que o paciente espera um atendimento que o HPSE não tem condições de oferecer?

Sim [1] Não [2] Às vezes [3] 
Quadros referentes às respostas dos questionários para os médicos, com os respectivos códigos, palavras/sentenças chaves e números parciais e totais de respostas

\section{Quadro no 16}

Q. 19 Cite 3 atributos de uma boa comunicação

\begin{tabular}{|c|c|c|c|c|c|c|c|c|}
\hline \multicolumn{5}{|c|}{ Questão 19} & \multicolumn{4}{|c|}{ Questão 20} \\
\hline Códigos & $19 \mathrm{~A}$ & 19B & $19 \mathrm{C}$ & Total & Códigos & $20 \mathrm{~A}$ & $20 B$ & Total \\
\hline 01 Ambiente & 0 & 4 & 2 & 6 & $\begin{array}{l}01 \text { Solução dos seus } \\
\text { problemas }\end{array}$ & 22 & 0 & 22 \\
\hline 02 Atenção & 5 & 4 & 2 & 11 & $\begin{array}{c}02 \text { Alguém que quer } \\
\text { ajudá-lo }\end{array}$ & 19 & 4 & 23 \\
\hline 03 Boa vontade & 6 & 5 & 7 & 18 & 03 Confiança & 8 & 0 & 8 \\
\hline 04 Bom diagnóstico & 0 & 3 & 2 & 5 & 04 Orientador & 0 & 0 & 0 \\
\hline 05 Clareza & 7 & 5 & 3 & 15 & 05 Como amigo & 0 & 0 & 0 \\
\hline $\begin{array}{l}06 \text { Concisão/ } \\
\text { objetividade }\end{array}$ & 5 & 5 & 2 & 12 & 06 Depende do paciente & 0 & 0 & 0 \\
\hline $\begin{array}{c}07 \text { Transmitir bem a } \\
\text { informação }\end{array}$ & 16 & 19 & 11 & 46 & 07 Como esperança & 8 & 0 & 8 \\
\hline $\begin{array}{c}08 \text { Relação médico- } \\
\text { paciente }\end{array}$ & 19 & 17 & 10 & 46 & 08 Respeito & 0 & 0 & 0 \\
\hline $\begin{array}{l}09 \text { Esclarecer bem ao } \\
\text { paciente o seu } \\
\text { problema }\end{array}$ & 3 & 6 & 14 & 23 & 09 Como um ser superior & 6 & 2 & 8 \\
\hline $\begin{array}{l}10 \text { Escutar o que } \\
\text { doente tem a dizer }\end{array}$ & 21 & 7 & 3 & 31 & 10 - Como médico & 10 & 3 & 13 \\
\hline 11 Outros & 4 & 8 & 10 & 22 & 11 Não respondeu & 6 & 0 & 6 \\
\hline 12 Não respondeu & 2 & 0 & 0 & 2 & 12 Outros & 9 & 0 & 9 \\
\hline Total & 88 & 83 & 66 & 237 & Total & 88 & 9 & 97 \\
\hline
\end{tabular}

Quadro no 17

Q. 20 O que você representa para o paciente? 
Quadro no 18

Q.21 O que o paciente espera de você?
Quadro no 19

Q.22 Cite 3 atributos para um bom atendimento ao paciente.

\begin{tabular}{|c|c|c|c||c|c|c|c|c|}
\hline \multicolumn{4}{|c||}{ Questão 21 } & \multicolumn{5}{c|}{ Questão 22 } \\
\hline Códigos & $21 \mathrm{~A}$ & $21 \mathrm{~B}$ & Total & Códigos & $22^{\mathrm{A}}$ & $22 \mathrm{~B}$ & $22 \mathrm{C}$ & Total \\
\hline 1 - A cura da doença & 14 & 3 & 17 & 1 - Atendimento & 7 & 19 & 19 & 45 \\
\hline 2 - Solução dos problemas & 38 & 5 & 43 & $\begin{array}{c}\text { 2- Relação médico- } \\
\text { paciente }\end{array}$ & 18 & 18 & 14 & 50 \\
\hline 3 - Apoio & 6 & 0 & 6 & 3 - Capacidade técnica & 3 & 8 & 5 & 16 \\
\hline 4 - Atenção & 15 & 1 & 16 & 4 - Comunicação & 23 & 19 & 13 & 55 \\
\hline 5 & 0 & 0 & 0 & $\begin{array}{c}5 \text { - Condições } \\
\text { adequadas }\end{array}$ & 5 & 7 & 10 & 22 \\
\hline 6 & 0 & 0 & 0 & 6 - Local & 7 & 5 & 1 & 13 \\
\hline 7 & 0 & 0 & 0 & 7 - Tempo & 15 & 9 & 5 & 29 \\
\hline 8 & 0 & 0 & 0 & 8 - Outros & 9 & 1 & 8 & 18 \\
\hline 9 & 0 & 0 & 0 & 9 - Não respondeu & 1 & 0 & 0 & 1 \\
\hline 10 & 0 & 0 & 0 & 10 & 0 & 0 & 0 & 0 \\
\hline 11 - Competência & 7 & 0 & 7 & 11 & 0 & 0 & 0 & 0 \\
\hline $12-$ Outros & 8 & 0 & 8 & 12 & 0 & 0 & 0 & 0 \\
\hline Total & 88 & 9 & 97 & Total & 88 & 86 & 75 & 249 \\
\hline
\end{tabular}


Quadro no 20

Q.23 O que poderia ser feito para melhorar a comunicação do médico com o paciente?
Quadro no 21

Q. 24 Você utiliza algum material de apoio? Qual?

\begin{tabular}{|c|c|c|c|c|c|c|c|}
\hline \multicolumn{4}{|l|}{ Questão 23} & & & & \\
\hline Códigos & $23 \mathrm{~A}$ & 23B & Total & & & & \\
\hline 1 & 0 & 0 & 0 & \multicolumn{4}{|c|}{ Questão 24} \\
\hline 2 - Diminuir no de consultas/pacientes & 17 & 2 & 19 & Códigos & $24 \mathrm{~A}$ & 24B & Total \\
\hline $\begin{array}{c}3 \text { - Infra-estrutura (condições de trabalho, } \\
\text { aparelhagem, paramédicos) }\end{array}$ & 11 & 6 & 17 & Outros & 22 & 4 & 26 \\
\hline 4 - Está relacionado aos médicos & 14 & 0 & 14 & Folhetos & 21 & 1 & 22 \\
\hline 5 - Está relacionado aos pacientes & 7 & 1 & 8 & Slides & 2 & 0 & 2 \\
\hline 6 - Relações de trabalho & 8 & 2 & 10 & Fotos & 1 & 5 & 6 \\
\hline 7 - Tempo & 18 & 4 & 22 & Total & 46 & 10 & 56 \\
\hline 8 - Outros & 9 & 1 & 10 & & & & \\
\hline 9 - Não respondeu & 4 & 0 & 4 & & & & \\
\hline Total & 88 & 16 & 104 & & & & \\
\hline
\end{tabular}


Quadro n-22

Q. 25 O que falta ao médico para que o atendimento melhore do ponto de vista da comunicação?
Quadro n을 23

Q. 31 O que você considera uma comunicação clara?

\begin{tabular}{|c|c|c|c|c|c|c|c|c|}
\hline \multicolumn{5}{|c|}{ Questão 25} & \multicolumn{4}{|l|}{ Questão 31} \\
\hline Códigos & $25 \mathrm{~A}$ & $25 B$ & $25 \mathrm{C}$ & $\mid$ Total & Códigos & $31 \mathrm{~A}$ & $31 B$ & Total \\
\hline 1 - Infra-estrutura & 13 & 5 & 0 & 18 & $\begin{array}{c}1 \text { - Explicação/ } \\
\text { esclarecimento/clareza/ } \\
\text { orientação }\end{array}$ & 33 & 3 & 36 \\
\hline $\begin{array}{c}2 \text { - Fatores que } \\
\text { dependem do médico }\end{array}$ & 30 & 3 & 1 & 34 & $\begin{array}{l}2 \text { - Falar e/ou explicar na } \\
\text { linguagem do paciente/leiga }\end{array}$ & 33 & 4 & 37 \\
\hline 3 & 0 & 0 & 0 & 0 & 3 - Conversar & 2 & 1 & 3 \\
\hline 4 - Tempo & 26 & 2 & 0 & 28 & $\begin{array}{c}4 \text { - Compreensão/ } \\
\text { entendimento mútuo do } \\
\text { paciente com o médico }\end{array}$ & 8 & 1 & 9 \\
\hline 5 - Dinheiro & 3 & 3 & 1 & 7 & 5 & 0 & 0 & 0 \\
\hline 6 - Não respondeu & 11 & 0 & 0 & 11 & $\begin{array}{c}6 \text { - Mais tempo para o } \\
\text { paciente }\end{array}$ & 5 & 0 & 5 \\
\hline 7 - Outros & 5 & 0 & 0 & 5 & 7 & 7 & 0 & 7 \\
\hline Total & 88 & 13 & 2 & 103 & Total & 88 & 9 & 97 \\
\hline
\end{tabular}


Quadros referentes às respostas dos questionários para os pacientes, com os respectivos códigos, palavras/sentenças chaves e números parciais e totais de respostas

Quadro no 24

Q.26 O que você acha que é para o médico?

\section{Quadro no 25}

Q. 27 O que você acha da comunicação entre o médico e o paciente durante 0 atendimento?

\begin{tabular}{|c|c|c|c|c|c|c|c|}
\hline \multicolumn{4}{|l|}{ Questão 26} & \multicolumn{4}{|c|}{ Questão 27} \\
\hline Códigos & $26 \mathrm{~A}$ & $26 \mathrm{~B}$ & Total & Códigos & $27 \mathrm{~A}$ & $27 \mathrm{~B}$ & Total \\
\hline 1 - Amigo & 4 & 2 & 6 & 1 - Boa/muito boa/ótimo & 73 & 1 & 74 \\
\hline 2 - Um doente/paciente & 20 & 0 & 20 & $\begin{array}{c}2 \text { - Difícil, devido ao pouco } \\
\text { tempo }\end{array}$ & 8 & 3 & 11 \\
\hline $\begin{array}{c}3 \text { - Alguém que ele quer } \\
\text { ajudar }\end{array}$ & 7 & 0 & 7 & 3 - Clara & 7 & 0 & 7 \\
\hline 4 - Cliente/consumidor & 3 & 0 & 3 & $\begin{array}{l}4 \text { - Depende do } \\
\text { médico/especialidade }\end{array}$ & 14 & 0 & 14 \\
\hline 5 - Depende do médico & 18 & 1 & 19 & 5 - Depende do paciente & 2 & 0 & 2 \\
\hline 6 - Depende do paciente & 4 & 1 & 5 & 6 - Muito importante & 18 & 2 & 20 \\
\hline 7 - Mais um paciente/número & 9 & 0 & 9 & 7 - Normal & 4 & 0 & 4 \\
\hline $\begin{array}{c}8 \text { - Pessoa que merece } \\
\text { atenção/precisa de ajuda/um } \\
\text { ser humano }\end{array}$ & 43 & 4 & 47 & 8 - Razoável/regular & 8 & 0 & 8 \\
\hline $\begin{array}{c}9 \text { - Pessoa que precisa ser } \\
\text { atendida }\end{array}$ & 14 & 0 & 14 & 9 - Ruim/muito ruim & 9 & 1 & 10 \\
\hline $\begin{array}{l}10 \text { - Não sei/não posso } \\
\text { responder }\end{array}$ & 5 & 0 & 5 & 10 - Outros & 9 & 0 & 9 \\
\hline 11 - Estorvo & 3 & 0 & 3 & 11 & 0 & 0 & 0 \\
\hline $\begin{array}{l}12 \text { - Vê bem/atende bem/não } \\
\text { posso reclamar }\end{array}$ & 11 & 0 & 11 & 12 & 0 & 0 & 0 \\
\hline 13 - Outros & 11 & 0 & 11 & 13 & 0 & 0 & 0 \\
\hline Total & 152 & 8 & 160 & Total & 152 & 7 & 159 \\
\hline
\end{tabular}


Quadro no 26

Q. 28 Você considera que uma comunicação clara sobre os procedimentos que o paciente tem que fazer ajudaria a melhorar esses procedimentos?
Quadro no 27

Q. 29 Cite 3 fatores que você considera importante para haver uma boa comunicação entre o médico e o paciente

\begin{tabular}{|c|c|c|c|c|c|c|c|c|}
\hline \multicolumn{4}{|l|}{ Questão 28} & \multicolumn{5}{|c|}{ Questão 29} \\
\hline Códigos & $28 \mathrm{~A}$ & $28 \mathrm{~B}$ & Total & Códigos & $29 \mathrm{~A}$ & 29B & $29 \mathrm{C}$ & Total \\
\hline $\begin{array}{c}1 \text { - A gente sabe o que tem } \\
\text { que fazer/entende o que } \\
\text { médico diz }\end{array}$ & 20 & 1 & 21 & 1- Atenção & 21 & 11 & 5 & 37 \\
\hline $\begin{array}{c}2 \text { - A gente ganha } \\
\text { confiança/fica mais seguro/ } \\
\text { sente-se mais a vontade }\end{array}$ & 20 & 0 & 20 & 2- Atendimento & 8 & 9 & 7 & 24 \\
\hline $\begin{array}{l}3 \text { - Comunicação clara é } \\
\text { fundamental }\end{array}$ & 12 & 1 & 13 & 3 - Atributos Paciente & 1 & 2 & 0 & 3 \\
\hline $\begin{array}{c}4 \text { - Paciente bem orientado } \\
\text { tem mais vontade de se } \\
\text { tratar }\end{array}$ & 15 & 1 & 16 & 4- Calma & 8 & 3 & 3 & 14 \\
\hline $\begin{array}{l}5 \text { - Paciente fica mais } \\
\text { animado, entusiasmado/ } \\
\text { sente-se melhor }\end{array}$ & 4 & 0 & 4 & 5 - Comunicação & 29 & 28 & 8 & 65 \\
\hline $\begin{array}{c}6 \text { - Se ele não explicar o } \\
\text { tratamento não vai ter bons } \\
\text { resultados }\end{array}$ & 8 & 1 & 9 & 6 - Relação & 55 & 41 & 32 & 128 \\
\hline $\begin{array}{l}7 \text { - Um bom diálogo/boa } \\
\text { explicação ajuda a } \\
\text { esclarecer o paciente }\end{array}$ & 18 & 4 & 22 & 7 - Remuneração & 1 & 2 & 2 & 5 \\
\hline $\begin{array}{l}8 \text { Quando o médico dá } \\
\text { atenção ajuda muito o } \\
\text { paciente }\end{array}$ & 8 & 0 & 8 & 8 - Tempo & 8 & 2 & 2 & 12 \\
\hline 9 - Outros & 0 & 13 & 13 & 9 - Seriedade Médico & 7 & 9 & 6 & 22 \\
\hline 10 - Preparo do médico & 0 & 3 & 3 & 10 - Tratamento & 6 & 3 & 6 & 15 \\
\hline $\begin{array}{l}11 \text { - Precisa seguir o } \\
\text { tratamento }\end{array}$ & 0 & 6 & 6 & 11 - Não sei & 5 & 0 & 1 & 6 \\
\hline 12 & 0 & 0 & 0 & 12 - Outros & 3 & 4 & 4 & 11 \\
\hline Total & 127 & 8 & 135 & Total & 152 & 114 & 76 & 342 \\
\hline
\end{tabular}




\section{Quadro no 28}

Q. 30 O que poderia ser feito para melhorar a comunicação entre o médico e o paciente?

\begin{tabular}{|c|c|c|c|}
\hline \multicolumn{4}{|l|}{ Questão 30} \\
\hline Códigos & $30 \mathrm{~A}$ & $30 \mathrm{~B}$ & Total \\
\hline $\begin{array}{l}1 \text { - Ambos devem se conscientizar da necessidade de haver um bom } \\
\text { relacionamento }\end{array}$ & 9 & 0 & 9 \\
\hline 2 - Depende do paciente & 3 & 2 & 5 \\
\hline 3 - Depende do médico & 5 & 0 & 5 \\
\hline 4 - Como está é bom, não precisa melhorar & 58 & 0 & 58 \\
\hline 5 - Uma linguagem mais acessível & 6 & 2 & 8 \\
\hline 6 - Mais atenção do médico & 13 & 0 & 13 \\
\hline 7 - Mais diálogo e explicação do médico & 6 & 4 & 10 \\
\hline 8 - Mais tempo de consulta & 10 & 0 & 10 \\
\hline 9 - Médico mais preparado & 3 & 0 & 3 \\
\hline 10 - É preciso calma dos médicos & 2 & 0 & 2 \\
\hline 11 - Melhor remuneração dos médicos & 7 & 1 & 8 \\
\hline 12 - Respeito do médico ao ser humano & 2 & 1 & 3 \\
\hline $13-$ Não sei & 7 & 0 & 7 \\
\hline 14 - Atendimento no guichê & 4 & 1 & 5 \\
\hline $15-$ Outros & 17 & 0 & 17 \\
\hline Total & 152 & 11 & 163 \\
\hline
\end{tabular}




\section{Bibliografia}

ABDO, Carmita Helena Najjar. Armadilhas da Comunicação: o médico, o paciente e o diálogo. São Paulo, Lemos Editorial, 1996.

ACOSTA MORENO, Marcela. Aspectos psicologico de la relacion medicopaciente. Unimetro, 1985.

AlBUQUERQUE, Rubens José de Castro. Relações Públicas no Hospital. São Paulo, Serviço de Documentação da Reitoria da USP, 1965.

ALVES, Cesar Paulo; RABELO, Miriam Cristina. Significação e metáforas, aspectos situacionais no discurso da enfermidade. In: Saúde e comunicação, visibilidades e silêncios. São Paulo, Husitec, 1995, p. 215.

AMERICAN Society for Hospital Public Relations: Basic Guide to Hospital Public Relations. $2^{\underline{a}}$ ed., Londres, Biblioteca Luiz Roberto.

ANDRADE, Cândido Teobaldo de Souza. Curso de Relações Públicas. São Paulo, Atlas, 1980.

Loyola, 1982.

Administração de Relações Públicas no Governo. São Paulo,

- Relações Públicas na sociedade em mudança. Campinas,

Revista Comunicarte, V.2, no 3, 1984.

. Para entender Relações Públicas. 4a ed., São Paulo, Loyola,

1988.

ANGERAMI, Valdemar Augusto. Psicologia hospitalar: a atuação do psicólogo no contexto hospitalar, (org.) de Camori. São Paulo, Traço, 1984 (série Psicoterapias alternativas, v.2).

ANZIEU, D.; MARTIN, J. Y. La dinámica de los grupos pequeños. Buenos Aires, Kapelusz, 1971, p. 111-128.

ASSOCIAÇÃO médica, dos médicos residentes e dos funcionários do IAMSPE; dos enfermeiros do HSPE. Carta Aberta à Comunidade do lamspe.

BACCHIN, Christiane das Garças. Relações Públicas de Relações Públicas: reflexões e contribuições. São Paulo, CRP/ECA/USP, 1991.

BAILE, W.F.; GROSS, R.J. Hypertension, psycosomatic and behavioral aspects. Primary care, 1979, p. 267-82.

BALINT, E.; NORELL, S. Seis minutos para o paciente. São Paulo, Manole, 1976, p. 23.

BALINT, Michael. O médico, seu paciente e a doença. Rio de Janeiro/São Paulo, Atheneu, 1988, p. 331. 
BARNLUND, Dean C. Comunicação: o contexto da mudança. In: MORTENSEN, C. David. Teoria da Comunicação. Wisconsin, Mosaico, 1980, p. 16.

BARROS FILHO, Clóvis de. Ética na comunicação. São Paulo, Moderna, 1995.

BERGAMINI, Cecília Whitaker. Desenvolvimento de Recursos Humanos: uma estratégia de desenvolvimento organizacional. São Paulo, Atlas, 1980.

BERNIK, Vladimir. Uma bem sucedida relação médico-paciente, é ainda hoje a maior garantia do sucesso terapêutico: Revista Brasileira de Medicina, V. 2, p.40-45, 1982.

BERWICK, Donald M.; GODFREY, A Blanton; ROESSNER, Jane. Melhorando a qualidade dos serviços médicos, hospitalares e da saúde. Makron Books, São Paulo, 1994.

BESSELAAR, José Van Den. Introdução aos Estudos Históricos. 3a ed., São Paulo, Editora Pedagógica e Universitária, 1973.

BIANCARELLI, Aureliano; SCHLEGEL, Rogerio. Médico é mal pago e estressado, diz estudo. Folha de São Paulo, p. 3-3, 06/10/96.

BOND, F. Fraser. Introdução ao Jornalismo. Trad. Cícero Sandroni, $2^{a}$ ed., Rio de Janeiro, Agir Editora, 1962.

BORDENAVE, Ivan Diaz; CARVALHO, Horácio Martins. Comunicação e Planejamento, Rio de Janeiro, Paz e Terra, 1979.

BUBER, Martin. Elementos do inter-humano. In: MORTENSEN, C. David. Teoria da Comunicação. Wisconsin, Mosaico, 1980, p. 409.

BUENO, Wilson da Costa. Comunicação para a saúde, uma experiência brasileira. São Paulo, Plêiade, 1996.

CAMPOS, Gastão Wagner de Souza. A saúde pública e a defesa da vida.

CAMPOS, Juarez de Queiroz, (et al.). O Hospital e seu planejamento, São Paulo, LTR, 1979.

CAPISANO, H. F. Manifestações iatrogênicas: conflitos neuróticos do médico prejudicam o paciente. Ars Curandi, v. 2, 1969

CASTRO, Cláudio de Moura. Estrutura e Apresentação de Publicações Científicas, São Paulo, McGraw-Hill do Brasil, 1976.

CLEVENGER, Theodore; MATTHEWS, Jack. Feedback. In: MORTENSEN, C. David. Teoria da Comunicação. Wisconsin, Mosaico, 1980, p. 55.

COHN, Gabriel. Sociologia da Comunicação: teoria e ideologia. São Paulo, Pioneira, 1973. 
COLCHER, I.S.;BASS, J.W. Penicilin treatment of streptococal Pharingitis. JAMA, 1972, p. 657-9.

CONDON JR., John C. Quando os homens se comunicam entre si. In: MORTENSEN, C. David. Teoria da Comunicação. Wisconsin, Mosaico, 1980, p. 189-200.

CONSELHO FEDERAL DE MEDICINA. Consulta n 6252/91. São Paulo, Conselho Federal de Medicina, 1991.

Pareceres. Brasília, Conselho Federal de Medicina, 1998.

COQUEIRO, Márcio César L. Relações Públicas, 1aㅡ ed., São Paulo, Sugestões Literárias, 1972.

CORDEIRO, Hésio. Saúde e Poder Público: Uma Nova Página na Imprensa. Saúde \& Imprensa,

DEMO, Pedro. Introdução à Metodologia da Ciência. São Paulo, Atlas, 1991, p. 56.

19 ANOS BASTAM! Jornal da Associação Médica do Instituto de Assistência Médica ao Servidor Público Estadual. São Paulo, junho/98, ano I, no 1, p.2-3.

DOWNS, C. Diagnosis through the questionnaire. Glenview, Illinois, Scott, Foresman and Company, p. 80-111.

ECO, Umberto. Como se Faz uma Tese em Ciências Humanas, 5a Ed., Lisboa, Editorial Presença, 1991.

FALCÃO, Daniela. Médico é treinado para a "guerra" no Rio. Folha de São Paulo, p. 6, 15/06/97.

FERRARI, Maria Rosana. Relações Públicas em hospitais. Tese de mestrado, São Paulo, ECA - USP, 1993.

FOLHA DE S. PAULO. Discurso de posse de José Serra como ministro da Saúde, p.1-6, 01/04/98.

Serra, p. 3-2, 31/05/98.

FORTES, Paulo Antonio de Carvalho. Ética e saúde. São Paulo, EPU, 1998, p. 66.

FREITAS, Sidinéia Gomes. A Comunicação Social como instrumento de poder, São Paulo, Tese de doutorado, Escola de Comunicação e Artes - USP, 1987.

GIBB, Jack R. Comunicação defensiva. In: MORTENSEN, C. David. Teoria da Comunicação. Wisconsin, Mosaico, 1980, p. 225.

GOLDHABER, Gerald M. Comunicación organizacional, 5aㅗ ed., México, Editorial Diana, 1991. 
GRUNIG, J.; HUNT, T. Managing Public Relations, New York, Holt, Rinehart \& Winston, 1994, p. 132.

GRUNIG, James E.; GRUNIG, Larissa A. Excellence in Public Relations and Communication Management, EUA, Lawrence Erfbaum Association Publisher, 1992, p. 285-327.

GURGEL, João Bosco Serra. Cronologia da Evolução Histórica das Relações Públicas, 3ํㅡㄹ. ed., Brasília, Linha Gráfica e Editora, 1985.

HABDA, O Relacionamento médico-paciente. in. Jornal do Cremesp - Órgão oficial do Conselho Regional de Medicina do Estado de São Paulo, no 72, outubro de 1992, v. 12, p. 11.

HARRISON, Roger. Defenses and the need to know. In: LAWRENCE, Paul; SEILER, George V. Organizational Behavior and Administration. Homewood, Irwin and Dorsey, p. 267.

HASTORF, Albert; CANTRIL, Hadley. They Saw a Game: a Case Study. Journal of Abnormal and Social Psychology 49, 1954, p. 129-134.

JANSEN, Roberta. Médicos se dizem pessimistas com a profissão. O Estado de S. Paulo, p. A17, 09/05/96.

JEAMMET, P.; REYNAUD M.; CONSOLI S. Manual de Psicologia Médica. São Paulo, Durban, 1989, p. 421.

JORNAL DO CREMESP. Ambulatório não é linha de montagem, julho/98, ano XVII, no 130 , p. 15.

A Lei № 10.241, na versão promulgada por Covas, maio/99, ano XVIII, no 141, p. 8-9.

JORNAL DO IAMSPE. DECAM (Departamento de Convênios e Assistência Médica Ambulatorial) faz reunião de balanço, outubro/98, ano IX, ํำ55, p.3.

KOTLER, Phillip. Marketing para organizações que não visam lucro, trad. H. de Barros, revisão técnica e prefácio à edição brasileira de Rubens da Costa Santos, São Paulo, Atlas, 1978.

Administração de marketing: análise, planejamento, implemento e controle, $3^{a}$ ed. São Paulo, Atlas, 1993.

KRUEL, Inês Rosinto Pinto. Comunicação institucional em saúde pública: uma pesquisa conscientizadora. Tese de doutorado. Escola de Comunicações e Artes, USP, São Paulo, 1994.

KUHN, Thomas S. A estrutura das revoluções científicas, São Paulo. Editora Perspectiva. 1989. 
KUNSCH, Margarida M. Krohling. "Relações Públicas Comunitárias". IN: Revista de Comunicação e Sociedade, Centro de Pós Graduação do Instituto Metodista de Ensino Superior. São Bernardo do Campo, № 11, junho de 1984, p. 131-150.

\section{Planejamento de Relações Públicas na Comunicação}

Integrada, $2^{\mathrm{a}}$ ed., São Paulo, Summus, 1989.

LAING, R.D.; PHILLIPSON, H.; LEE, A.R. Interação e interexperiência em diádes. In: MORTENSEN, C. David. Teoria da Comunicação. Wisconsin, Mosaico, 1980, p. 386.

LEAVITT, Harold; MUELLER, Ronald. Some Effects of Feedback on Communication. Human Relations 4, 1951, p. 401-410.

LEOPOLDO e SILVA, Franklin. Virtude de fazer o bem. São Paulo, Conselho Federal de Medicina, 1997, p. 8.

LOPES, Boanerges e NASCIMENTO Josias. Saúde e Imprensa: o público que se dane, Rio de Janeiro, Mauad, 1996.

LAMAMOTO, Marilda Vilella. Renovação e Conservadorismo no Serviço Social, São Paulo, Summus, 1990 (Coleção Novas Buscas em Comunicação, U 35).

MACHADO, M.H. Os médicos no Brasil: um retrato da realidade. Rio de Janeiro, FIOCRUZ, 1997, p. 244.

MACHLINE, Claude et al. O Hospital e a visão administrativa contemporânea, coordenador Ernesto Lima Gonçalves, São Paulo, Pioneira, 1983.

MAGALHÃES, Álvaro (org.). Dicionário Enciclopédico Brasileiro. Rio de Janeiro/Porto Alegre/São Paulo, Ed. Globo, 1951, p. 573, 874-5.

MARMOR, J. $O$ médico como psicoterapeuta. In: USDIN G.; LEWIS, J.M. Psiquiatria na prática médica. Rio de Janeiro, Guanabara Koogan, 1981, p. 404-415.

MATTELART, Armand. Comunicação Mundo - História das Idéias e das Estratégias, Petrópolis, Vozes, 1994, p.261.

MINCIOTTI, Sílvio Augusto. O sistema de informações de marketing como suporte para a adoção do Marketing Estratégico - O Desenvolvimento de um modelo, São Paulo, 1992. Tese de doutorado, Faculdade de Economia, Administração e Contabilidade - USP.

MIR, Luís. Ensino Médico In: Médicos. São Paulo, Hospital das Clínicas, marçoabril/1998

MORTENSEN, C. David. Teoria da Comunicação. Wisconsin, Mosaico, 1980.

NASH, Laura L. Ética nas Empresas: boas intenções à parte, São Paulo, Makron Books, 1993. 
NASSAR, Maria Rosana Ferrari. Relações Públicas em Hospitais, São Paulo, 1993.

Tese de mestrado, Escola de Comunicação e Artes - USP.

NOGUEIRA-MARTINS, Luiz Antonio; NOGUEIRA-MARTINS, Maria Cezira

Fantini. O exercício atual da Medicina e a relação médico-paciente.

In: Revista Brasileira Clínica \& Terapêutica. São Paulo, Sociedade

Brasileira de Clínica Médica, março/98, p. 60-2.

Novo Dicionário Aurélio da Língua Portuguesa. Editora Nova Fronteira, 1986.

OLIVEIRA, Ivone de Lourdes. Relações Públicas: Os impasses da teoria e os desafios da ação profissional em Belo Horizonte, São Paulo, 1983. Tese de mestrado, Escola de Comunicação e Artes - USP.

PAJUElO, Nelly Amelia Becerra. Perfil das Relações Públicas na América Latina, São Paulo, 1983. Tese de mestrado, Escola de Comunicações e Artes - USP.

PERUZZO, Cicilia Krohling. Relações Públicas no modo de produção capitalista, São Paulo, Cortez, 1982.

PERUZZO, Cicilia Krohling; KUNSCH, Margarida Maria Krohling (orgs.). Transformações da Comunicação: Ética e Técnicas, Coleção Intercom de comunicação, no 3, Vitória: Ed. Fundação Ceciliano Abel de Almeida/UFES, Pref. Municipal de Vitória, 1995.

PESSINI, Leocir; BARCHIFONTAINE, Christian de Paul. Problemas Atuais de Bioética. São Paulo, Loyola, 1994.

PINHO, J.B. Propaganda Institucional: Usos e Funções da Propaganda em Relações Públicas, São Paulo, Summus, 1990 (Col. Novas Buscas em Comunicação).

PITTA, Áurea M. da Rocha. Saúde e comunicação, visibilidades e silêncios. Org. Husitec. São Paulo, Hucitec, 1995.

Plantonista vive sob o domínio do medo. Jornal Folha de São Paulo, p. 7, 15/06/97.

RAMOS, Osvaldo Luiz. Dos pajés à ciência pura In: Médicos. São Paulo, Hospital das Clínicas, março-abril/1998

READ, Ross et al. The Effective Health Care Executive: A Guide to a Winning Management Style, Michigan, Terence F. Moore, cap. 5, p. 60, 1986.

REGO, Francisco Gaudêncio Torquato do. Comunicação Empresarial/Comunicação Institucional, São Paulo, Summus, 1986.

1992.

Poder, Cultura, Imagem, Comunicação, São Paulo, Pioneira, 
Revista Médicos. Entrevista com Professor Doutor Marcello Marcondes Machado. São Paulo, Hospital das Clínicas, março/98, p. 4-9.

ROLIM, Ernani. A importância do clínico no Século XXI. Palestra de abertura do Congresso Brasileiro de Clínica Médica. São Paulo, 1997.

SACKETT, D.L.; HAYNES, R.B. Randomized clinical trial of strategies for improving compliance in primary hipertensives. Lancet, 1975, p. 1205-07.

SANSON-FISCHER, R.; MAGUIRE, P. Should skills in communicating with patients be taught in medical schools? Lancet, 1980, p. 523-6.

SELLTIZ, Clarice et al. Métodos de pesquisa nas Relações Sociais, São Paulo, E.P.U., 1974.

SIMÕES, Roberto Porto. Relações Públicas: função política, Porto Alegre, Sagra, 1990.

SIMONS, George J.; McCALL, J.L. Percepção e avaliação social. In: MORTENSEN, C. David. Teoria da Comunicação. Wisconsin, Mosaico, 1980, p. 72.

TEIXEIRA, José Manuel de C. O hospital e a visão administrativa contemporânea. Calude Machline. et. al.; coord. Ernesto Lima Gonçalves, São Paulo Pioneira, 1983, p. 25.

VASSALLO, Cláudia. SOCORRO! Por que os preços cobrados pelos hospitais brasileiros são tão altos. Cláudia Vassallo. Revista Exame, p. 84/96, no 635, 7/maio/97.

VIEIRA, Liszt. Cidadania e globalização. São Paulo, Record, 1997.

WARDMAN, Kellie T. Criando organizações que aprendem. São Paulo, Futura, 1996.

WATZLAWICK, Paul, et. al. Pragmática da comunicação humana. São Paulo, Cultrix, 1973.

ZÉMOR, Pierre. La communication publique, Presses Universitaires de France, p. 5, 1995. 